\title{
Orta Anadolu Bölgesi'nde buğdayda Avrupa Sünesi (Eurygaster maura L. Hemiptera: Scutelleridae)'nin neden olduğu ürün kayıpları ve ekonomik zarar eşiğinin belirlenmesi
}

\author{
Mümtaz ÖZKAN $^{1} \quad \underline{\text { Numan E. BABAROĞLU }}^{1} \quad$ Atilla GÖKDOĞAN $^{1}$ \\ Mustafa KAN ${ }^{2} \quad$ Erhan KOÇAK ${ }^{3}$
}

\begin{abstract}
Determination of the crop losses by sunn pest (Eurygaster maura L. Hemiptera: Scutelleridae) and economic damage threshold in Central Anatolia Region
\end{abstract}

This study was carried out to determine economic damage threshold of sunn pest (Eurygaster maura L. Hemiptera: Scutelleridae) in the field conditions in Central Anatolia Region. Revealing the economic damage threshold was based on the damage rate of kernel (rate of consume). According to the results, it was determined that there was no damage of dry-heart leaves caused by overwintered adult. Also, it was revealed that the white spike damage was too low (0.09) to control this pest. It was determined that the quality losses were occured in lower populations compared to quantitative losses caused by new generation adults and nymphs. It was found out that the rate of kernel damage was changed by depending on the pest, number of kernel and number of kernel in spikes in per square meter. When average of 407 spikes in $\mathrm{m}^{2}, 26$ number of kernel in spikes and 3.5\% of disturbed quality of wheat acceptable upper rate of kernel damage tolerance limit were taken in the conditions of average climate for many years in Central Anatolia Region it was determined that the threshold of economic damage was appropriate as 7 individuals $/ \mathrm{m}^{2}$. However, it was concluded that it would be appropriate to revise the threshold of economic damage only that year, if necessary, by evaluating conditions of climate which effect yield of wheat until to control sunn pest.

Keywords: Wheat, sunn pest, Eurygaster maura, Central Anatolia Region, crop losses, economic damage threshold,

\footnotetext{
${ }^{1}$ Ankara Zirai Mücadele Merkez Araştırma Enstitüsü Müdürlüğü, ANKARA

2 Ahi Evran Üniversitesi, Ziraat Fakültesi, KIRŞEHİR

${ }^{3}$ Süleyman Demirel Üniversitesi, Ziraat Fakültesi, ISPARTA

Sorumlu yazar (Corresponding author) e-mail: nbabaroglu@gmail.com

Alınış (Received): 17.03.2017, Kabul ediliş (Accepted): 23.05.2017
} 
Orta Anadolu Bölgesi'nde Süne (Eurygaster maura L. Hemiptera: Scutelleridae)'nin buğdayda meydana getirdiği ürün kayıpları ve mücadelesinde uygulanacak ekonomik zarar eşiğini belirlemek amacıyla doğa koşullarında yürütülen çalışmalar sonucunda; kışlamış erginlerin meydana getirdiği kurtboğazı zararının görülmediği, akbaşak zararının ise mücadeleye gerek duyulmayacak oranda (0.09) olduğu belirlenmiştir. Nimf ve yeni nesil erginlerin tanede beslenmesi nedeniyle kalite yönüyle oluşan kayıpların kantite yönüyle oluşan kayıplara göre çok daha düşük zararlı yoğunluklarında meydana geldiği saptanmıştır. Ekonomik zarar eşiğini belirlemek için tanenin zarar görme oranı (emgi oranı) temel alınmış, bu oranın $\mathrm{m}^{2}$ ' deki zararlı ve başak sayısı ile başaktaki tane adedine bağlı olarak değiştiği ortaya konmuştur. Orta Anadolu Bölgesi'nde uzun yıllar ortalama iklim koşullarında $\mathrm{m}^{2}$ ' de ortalama 407 adet başak, başaktaki tane sayısının 26 adet ve buğdayın kalitesini bozan kabul edilebilir üst emgi oranın da \%3.5 olarak alındığında ekonomik zarar eşiğinin $7 \mathrm{adet}^{-2} \mathrm{nimf}$ olarak alınmasına, ancak süne mücadelesi zamanına kadar buğdayın verimini etkileyen iklim koşulları da değerlendirilerek, gerekirse ekonomik zarar eşiğinde o yıla özgü revize yapılmasının uygun olacağı ortaya konulmuştur.

Anahtar kelimeler: Buğday, süne, Eurygaster maura, Orta Anadolu Bölgesi, ürün kayıpları, ekonomik zarar eşiği

\section{GíRIŞ}

Tarımın tarih sahnesine çıkması, ilk yerleşik toplulukların oluşmaya başladığı dönem olarak kabul edilmektedir. Tarımın gelişmesiyle birlikte insanlık tarihi dönüşüm geçirmiştir. Bu gelişmeyi başlatan etkenlerden birisi de buğdaydır. Yapılan arkeolojik kazılar sonucu Anadolu'nun buğdayın ilk evcilleştirildiği ve tarımının yapıldığı topraklar olduğu ortaya konulmuştur (Heun et al. 1997, Luo et al. 2007, Bilgic et al. 2016). Buğdayın evcilleştirilmesi yaklaşık 12.000 yıl önce başlamış ve günümüzde uygarlığın gelişiminde bir dönüm noktası olarak kabul edilmektedir. Genetik analizler, tek taneli einkorn ve emmer buğdayının evcilleştirilmesinin Karacadağ (Diyarbakır) çevresinde yapıldığını göstermiştir (Heun et al. 1997, Luo et al. 2007). Yine Çatalhöyük’te (Çumra-Konya) yapılan arkeolojik kazılardan M.Ö 6400-6200 yıllarına ait olduğu tahmin edilen buğday örnekleri elde edilmiştir (Bilgic et al. 2016).

Başta buğday olmak üzere tarım ürünleri içerisinde temel besin maddesi olarak değerlendirilen tahıllar, hem Dünyada hem de Ülkemizde gıda güvencesi olarak değerlendirilmektedir. İnsanoğlunun besin olarak tükettiği bitki türlerinin sayısı son derece sınırlıdır. 195 bin çiçekli bitki türünden çoğunun insan tarafından kullanılabilecek yenilebilir parçalar üretmesine rağmen; ancak \%0.1'den (300'den daha az) az tür gıda için kullanılmaktadır (Cordain 1999). Yaklaşı 17 bitki türü, insanlık besin ihtiyacının \%95'ini sağlarken, bu oran içerisinde tahıllar en büyük paya sahiptir. Buğday, mısır, pirinç, arpa, sorgum, yulaf, çavdar ve darıdan oluşan 8 hububat türü, besin enerjisinin $\% 56$ 'sın1, proteinin \%50'sini sağlamaktadır (Stoskopf 
1985). Mangelsdorf (1966), tahılların kelimenin tam anlamıyla insanlık ile açlık arasında durduğunu belirtmektedir.

Günümüzde Dünyada tarımı yapılan 160 ürün içerisinde 220 milyon hektar ekim alanı ile buğday birinci sırada yer almaktadır (Anonymous 2014). En yüksek ekim alanına sahip buğdayın, $30^{\circ}-60^{\circ}$ kuzey enlemleri ile $27^{\circ}-40^{\circ}$ güney enlemleri arasında en uygun yetiştirme alanları olmasına rağmen (Nuttonson 1955), bu sınırların dışında, kuzey kutup dairesinden ekvatora yakın yüksekliklere kadar yerlerde de yetiştirilebilmektedir. Yükseklik olarak buğday, deniz seviyesinden 3000 metre yüksekliğe kadar tüm yükseltilerde yetişebilmektedir. Optimum gelişme sıcaklığ 1 yaklaşık $25^{\circ} \mathrm{C}$ 'dir (Briggle 1980). Dünyada buğday tarımı yapılan alanını alanın 3/4'ü ortalama yıllık 375-875 mm yağış alırken, yıllık 250-1750 mm yağış alan yerlerde de yetiştirilebilmektedir.

Buğday, Dünyada 220 milyon hektar ekim alanı, 729 milyon ton üretim miktarı, dünya ticaretine konu olan 162 milyon ton alım-satım miktarı karşılığ 53 milyon \$ ticaret hacmi ile insanlık için vazgeçilmez bir üründür (Anonymous 2014). Ülkemizde ise çalışan nüfusun yaklaşık \%21'i tarım, ormancılık ve balıkçılık kolunda istihdam edilmekte olup ülke ekonomisine 98 milyar $€$ 'lik bir üretim değeri sağlamakta ve 157 milyon \$'lık bir dış satım gerçekleştirilmektedir (Anonim 2016).

İnsan beslenmesinde alternatifsiz bir bitki olan buğday, un haline getirilerek ekmek ve diğer unlu g1daların üretiminde kullanıldığı gibi bulgur, makarna, irmik, bisküvi gibi değişik ürünler şeklinde de günlük beslenmemizde yer almaktadır. Öğütme işlemi sonucu ortaya çıkan kepek ve diğer yan ürünler ile düşük vasıflı buğdaylar hayvan yemi olarak da kullanılmaktadır. Ayrıca son yıllarda yenilenebilir enerji kaynağ1 olarak kullanılan bio-etanol üretiminde de buğday hammadde olarak kullanılabilmektedir.

Ülkemizde geçmişten günümüze buğday üretimindeki gelişmeleri incelediğimizde (Çizelge 1, Şekil 1), 1938-1940 döneminde yaklaş1k 1.5 milyon ton olan buğday üretimimiz 1966-1970 döneminde 10 milyon tona, 2011-2015 döneminde ise yaklaşık 21 milyon tona çıkmıştır. Üretimde meydana gelen bu artışta, 1970 yılına kadar ekim alanlarındaki artışın etkisi olurken, daha sonraki dönemlerde ise yetiştirme tekniklerindeki iyileştirmeler üretim artışına önemli katkı sağlamıştır. Nitekim 1938-1940 döneminde 4 milyon ha olan buğday ekim alanları, 1966-1970 döneminde 8,3 milyon hektara, yani 2006-2010 dönemindeki düzeyine ulaşmıştır. Birim alandan elde edilen verim ise 1938-1940 döneminde $1030 \mathrm{~kg} / \mathrm{ha}$ iken, 19661970 döneminde 1200 kg/ha ulaşmıştır. Buğday ekim alanlarında 1970 den 2010'a artış olmazken verimdeki artış \%116 olarak gerçekleşmiştir. Yine ülkemizdeki son 15 yıllık (2001-2015) veriler incelendiğinde, buğday ekim alanlarının yaklaşık 1.5 milyon ha azalmasına rağmen üretim miktarında (2014 yılında meydana gelen kuraklığın etkisi göz ardı edildiğinde) yaklaşık 1.5 milyon ton artış olduğu görülmektedir. Aynı dönemdeki verimin de $2070 \mathrm{~kg} / \mathrm{ha}$ 'dan $2700 \mathrm{~kg} / \mathrm{ha}$ 'a yükseldiği ve söz konusu süreçte ekim alanlarının azalmasına karşıllı üretimin azalmadan devam edebilmesi sağlanmıştır. Günümüzde de buğday ekim alanlarının mısır, 
Orta Anadolu Bölgesi’nde buğdayda Avrupa Sünesi (Eurygaster maura L. Hemiptera: Scutelleridae)’nin neden olduğu ürün kayıpları ve ekonomik zarar eşiğinin belirlenmesi

ayçiçeği, aspir, kanola, yonca vb. gibi ürünlerin tarımına tahsis edilmesi nedeniyle ekim alanlarındaki bu azalma eğiliminin devam edeceği beklenilmektedir. Buğday ekim alanlarının azalmasına karşılık üretimin azalmadan devam edebilmesi için birim alandan elde edilen ürün miktarını arttıran üretim tekniklerinin yanında, söz konusu alanda ürün kaybının en aza indiren tedbirlerinde alınması zorunludur. Türkiye'nin nüfusu 1940 yılında yaklaşık 17.8 milyon iken, 2015 yılı itibarıyla 78.7 milyon olmuştur (Anonim 2016). Bu süre içerisinde nüfusun yaklaş1k 4.5 kat artmış olmasına rağmen, genel olarak ülkemizde buğday talebinin karşılanması konusunda bu güne kadar herhangi bir darboğazın yaşanmamasını sağlamıştır. Gelecekte de herhangi bir darboğazın yaşanmaması için üretimdeki bu artışın sürdürülebilirliğinin sağlanması gerekmektedir.

Tarımsal üretimi artırmada, yüksek verimli tohum kullanımı, sulama, gübreleme gibi tekniklerin yanında, üretim kayıplarına sebep olan unsurların başında gelen zararlı organizma olarak adlandırılan hastalık, zararlı ve yabancı otlarla mücadelenin çok önemli bir yeri vardır. Dünyada tüm tarım ürünlerinde zararlı, hastalık ve yabancı otlarla mücadele yapılmadığında üretimde \%31-42 (ortalama \%36.5) oranında kayıp meydana gelmektedir. Bu kaybın \%14.1'i hastalıklardan, \%10.2'si böceklerden ve $\% 12.2$ 'si de yabancı otlardan meydana gelmekte, sadece hastalıklardan oluşan ürün kayıplarının toplam parasal bedelinin 220 milyar dolar olduğu tahmin edilmektedir (Agrios 2005).

Çizelge 1. Türkiye'de 1946-2015 yılları buğday ekim alanı, üretim ve verim miktarları

\begin{tabular}{|l|l|l|l|}
\hline Yillar & Ekim alanı (1000 ha) & Verim $\left(\mathbf{k g ~ h a}^{-\mathbf{1}}\right)$ & Üretim (1000 ton) \\
\hline $1938-1940$ & 4077 & 1030 & 1574 \\
\hline $1941-1945$ & 3949 & 840 & 5266 \\
\hline $1946-1950$ & 4206 & 860 & 3617 \\
\hline $1951-1955$ & 6013 & 1070 & 6434 \\
\hline $1956-1960$ & 7435 & 1060 & 7881 \\
\hline $1961-1965$ & 7960 & 1080 & 8584 \\
\hline $1966-1970$ & 8353 & 1200 & 10020 \\
\hline $1971-1975$ & 8814 & 1400 & 12372 \\
\hline $1976-1980$ & 9256 & 1820 & 16837 \\
\hline $1981-1985$ & 9167 & 1860 & 17059 \\
\hline $1986-1990$ & 9343 & 2030 & 18946 \\
\hline $1991-1995$ & 9597 & 2010 & 19256 \\
\hline $1996-2000$ & 9374 & 2070 & 19441 \\
\hline $2001-2005$ & 9260 & 2160 & 20005 \\
\hline $2006-2010$ & 8166 & 2330 & 19060 \\
\hline $2011-2015$ & 7804 & 2700 & 21110 \\
\hline
\end{tabular}




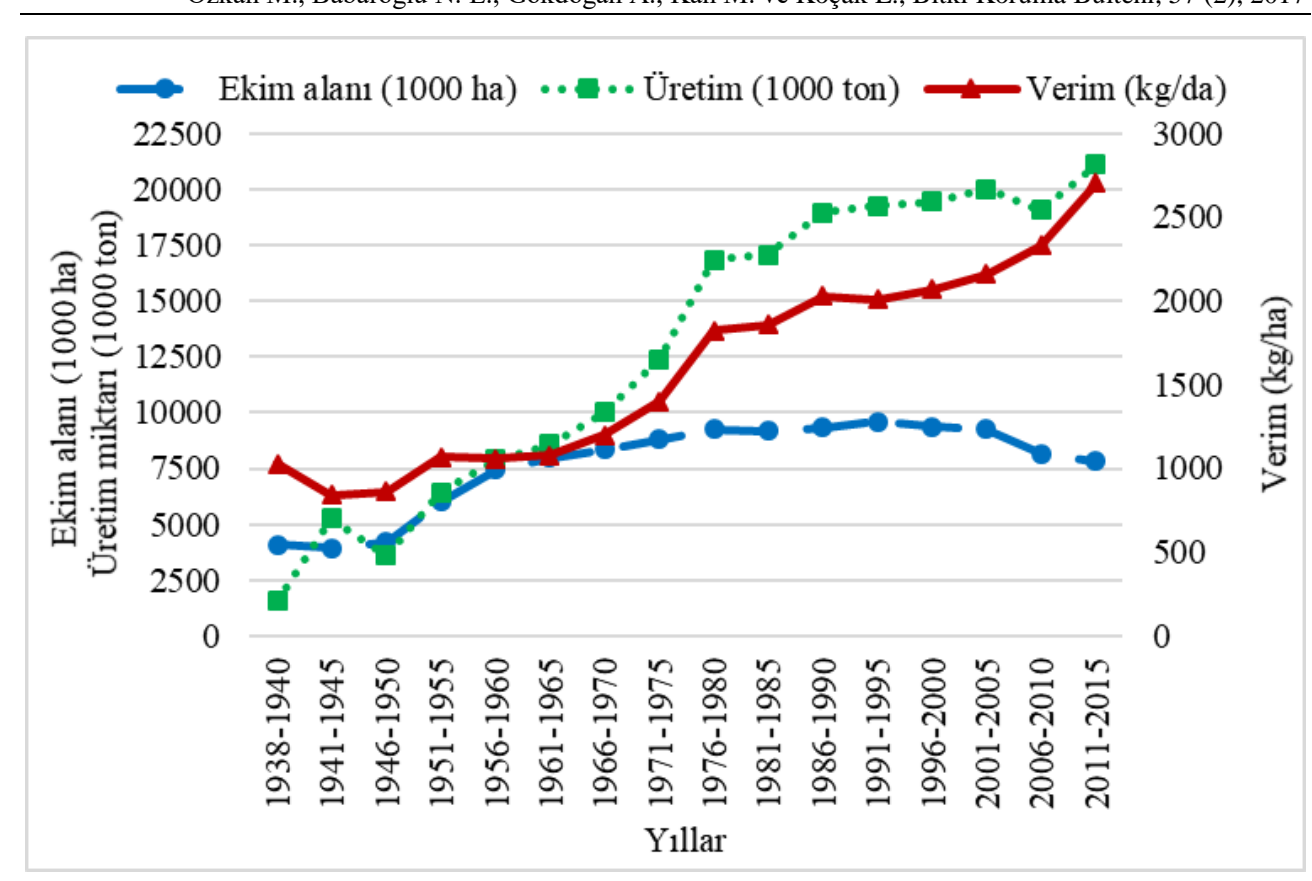

Şekil 1. Türkiye'de 1946-2015 yılları buğday ekim alanı, üretim ve verim miktarları

Buğday yetiştiriciliğinde verim ve kaliteyi olumsuz yönde etkileyen faktörlerin başında hastalık, zararlı ve yabancıot kaynaklı bitki koruma ile ilgili sorunlar gelmektedir. Buğdayda önemli ölçüde ürün kayıplarına sebep olan zararlıların başında Süne (Eurygaster spp.) gelmektedir.

Hemiptera takımı, Scutelleridae familyası, Eurygaster cinsine bağlı olan sünenin dünyada 15, ülkemizde ise 7 türü bulunmakla birlikte ülkemizde E. integriceps Put. (süne), E. maura L. (Avrupa sünesi) ve E. austriaca Schrk. (Yass1 vücutlu süne) türleri ekonomik açıdan önemlidir. Bu türlerden E. integriceps Güney, Güneydoğu Anadolu, Ege ve Trakya'nın, E. maura ise İç Anadolu Bölgesi'nin hakim türleridir (Lodos 1961, Koçak ve Babaroğlu 2005, Koçak ve ark. 2007, Özkan ve Babaroğlu 2015).

Sünenin nimf ve erginleri, çeşitli fenolojik dönemlerde bulunan buğdaygilleri hortumları ile sokup emmek suretiyle zarar yaparlar. Kış1 geçirdikten sonra, ilkbaharda ovalardaki hububat tarlalarına göç eden kışlamış erginler, henüz kardeşlenme döneminde olan buğday ve diğer bazı buğdaygillerin saplarını emerek özsuyunu alırlar. Emilen saplar zamanla sararır ve kurur, başak bağlamazlar. Bu zarar şekline "kurtboğazı" denilmektedir.

Zamanla bitkiler geliştikçe, beslenmesini bitkilerin yukarı kısımlarında sürdüren kışlamış erginler; başaklar henüz yaprak kılıfı içerisindeyken, çiçek döneminde ve tane bağlarken, yine saplarda beslenerek başakların beyazımsı bir renk almalarına, kurumalarına ve dolayısıyla bunların tane bağlamasına engel olurlar. Kışlamış 
Orta Anadolu Bölgesi’nde buğdayda Avrupa Sünesi (Eurygaster maura L. Hemiptera: Scutelleridae)’nin neden olduğu ürün kayıpları ve ekonomik zarar eşiğinin belirlenmesi

erginlerin bu şekildeki zararına "akbaşak" adı verilmektedir.

Başaklardaki taneler süt olumuna gelmeye başladığı sırada, kışlamış erginlerin popülasyonlarıda gittikçe azalmaya başlar. Bunların bıraktığı yumurtalardan çıkan nimfler hububatın bu döneminde, gittikçe artan bir yoğunluk ve oburlukla taneleri sokup emmeğe başlarlar. Nimf dönemleri ile yeni nesil erginlerin beslenmesi sonucu oluşan zarar önem kazanır. Çünkü bu devrede, hububat süt ya da sarı olum dönemindedir. Özellikle 4. ve 5. dönemdeki nimflerle yeni nesil erginlerin başaklarda beslenmesi sonucu taneler hem çimlenme güçlerini hem de ekmeklik ve makarnalık özelliklerini büyük ölçüde kaybederler. 4. ve 5. dönem nimf ve yeni nesil ergin yoğunluğunun fazla olduğu yer ve yıllarda mücadele yapılmaması halinde \%100'e varan oranlarda nicelik ve nitelik yönünden zarar meydana gelmektedir.

Türkiye’de Süne; ilk defa 1927-1929 yıllarında Güney Anadolu'nun bazı alanlarında (Gaziantep, Kilis, Cebeli Bereket, İslâhiye) (Madenoğlu 1929), 1939-1941 yıllarında da Güneydoğu Anadolu bölgesinde salgın yapmıș ve salgınlar 1955-1959 ve 19651973 yıllarında periyodik olarak devam etmiştir. Sözü edilen bölgelerde 1977 yılında yeniden başlayan salgın, günümüze değin aralıksız olarak devam etmektedir. Ege ve Trakya'da 1982, Orta Anadolu Bölgesi’nde 1988, Marmara Bölgesi’nde 1990 yılında ilk kez Süne salgını başlamış olup günümüze kadar devam etmektedir.

Devlet 1928 yılından itibaren süne mücadelesini ele almış ve bu dönemde ergin süneler elle, kalburla, atrapla toplatılarak fiziksel mücadele yapmaya çalışılmıştır. Süne erginlerinin toplanması 1928 y1lından 1954 yılına kadar devam etmiştir. Sünenin altında kışladığı, kışlak bitkileri 1939 yılından itibaren alev makinesi ve gazyağı ile yakılmaya başlanmıştır. Ancak doğanın tahrip edilmesi ve toprak erozyonuna sebep olduğunun anlaşılması üzerine 1954 yılından itibaren bu uygulamadan vazgeçilmiştir. Fiziksel mücadele olarak 1928 yılında başlayan süne mücadelesi 1955 yılından itibaren ağırlıklı olarak havadan ilaçlama uygulamaları olarak kimyasal mücadele şekline dönüşmüştür. Devlet mücadelesi şeklinde 1928 y1lında başlayan süne mücadelesi 2009 yılından itibaren "Yönetimli Çiftçi Mücadelesi” șekline dönüșmüș ve bu tarihten itibaren havadan yapılan ilaçlamalara son verilerek süne mücadelesinde tamamen yer aletlerine geçilmiştir. Orta Anadolu bölgesinde ilk defa Ankara, Burdur ve Isparta illerinde 1988 yılında başlayan süne mücadelesi salgının büyüklüğüne bağlı olarak yıldan yıla değișen miktarlarda günümüze değin sürmüştür. Söz konusu mücadele ağırlıklı olarak Ankara, Kırşehir, Kayseri, Nevşehir, Kırıkkale, Yozgat, Aksaray, Konya ve Eskişehir illerinin buğday ekim alanlarında olmak üzere; Afyon, Burdur, Isparta, Karaman, Niğde ve Sivas illeri ekim alanlarında yapılmıştır.

Süne salgınlarının boyutlarının ortaya konulması bakımından zararlı ile yapılan mücadele incelendiğinde Orta Anadolu Bölgesi’nde ilk kez mücadeleye 1988 y1lında başlanılmıştır (Özkan ve Babaroğlu 2015). 1993 yılında 1 milyon dekarın üzerine, bunu takip eden iki yıl boyunca da 3 milyon dekarın üzerine çıkmıştır. 1996-2000 yıllar1 süresince ilaçlanan alan tekrar 1 milyon dekarın altına düşmüștür. 2001 yılında başlayan 2. salgın periyodu 2005 yılına kadar 4 yıl sürmüştür. 2005 ve 2006 
yıllarında yeniden 500 bin dekarın altına inen ilaçlanan alan miktarı 2007 yılından itibaren 2 milyon dekarın üzerine çıkmış salgın 2014 yılına kadar sürmüştür. 2015 yılından itibaren tekrar 1 milyon dekarın altına düşmüştür. Görüleceği gibi bölgemizde 1993-1996 yıllarında 4 yıl, 2001-2004 yıllarında 4 yıl ve 2007-2014 yıllarında 8 yıl süren döngülü 3 salgın meydana gelmiştir (Çizelge 2 ve Şekil 2).

Orta Anadolu Bölgesi'nde entegre mücadele anlayışı içerisinde yürütülen süne mücadelesinde karar verme kriterleri olarak, geçmiş yıllarda Güneydoğu Anadolu Bölgesi'nde yapılan araştırmalar sonucu ortaya konulan esaslar kullanılmıştır (Kılıç 1988, Şimşek 1998). Ülke genelinde süne mücadelesinin yönlendirilmesinde de bu veriler baz olarak alınmaktadır. Fakat baz olarak alınan bu değerlerin ekolojik farklılıklar gösteren ülkemizin Güneydoğu Bölgesi dışındaki bölgelerinde bazı durumlarda sorunu çözmede yetersiz kaldığ 1 da gözlenmiştir. Bu durumun farklı ekolojik koşullarda gerek böcek biyolojisi gerekse de bitki fenolojisinden dolay1 ortaya çıkabilecek değişimlerden kaynaklanabileceği de düşünülmektedir. Bu nedenle süne açısından halen ülke genelinde kullanılmakta olan ekonomik zarar eşiğinin (10 nimf $\mathrm{m}^{-2}$ ) bölgeler bazında yeniden gözden geçirilmesi ihtiyacı ortaya çıkmıştır. Bölgemiz koşullarında gerek nicelik ve nitelik yönünden ürün kayıplarının, ve gerekse sünenin ekonomik zarar eşiğinin ortaya konulmasını amaçlayan bu çalışma; sonuçta Orta Anadolu Bölgesi’ne özgü ekonomik zarar eşik'lerinin dikkate alınarak kimyasal mücadele yapılmasının çevre ve insan sağlığı açısından yaratacağı kazanımlar ile ülke ekonomisi için kaliteli buğday üretimi sağlanması gibi iyileştirmeleri de beraberinde getirerek genelde buğday üreticisi durumunda olan Orta Anadolu çiftçisine de büyük katkı sağlayacaktır.

Çizelge 2. Orta Anadolu Bölgesinde 1988-2016 yıllarında süneye karşı kimyasal mücadele yapilan alan

\begin{tabular}{|l|l|l|l|}
\hline Yıllar & İlaçlanan alan (ha) & Yıllar & İlaçlanan alan (ha) \\
\hline 1988 & 219950 & 2002 & 4160610 \\
\hline 1989 & 345170 & 2003 & 2325842 \\
\hline 1990 & 17340 & 2004 & 2627161 \\
\hline 1991 & 231000 & 2005 & 348124 \\
\hline 1992 & 194690 & 2006 & 107016 \\
\hline 1993 & 1086238 & 2007 & 2025633 \\
\hline 1994 & 3522562 & 2008 & 3560077 \\
\hline 1995 & 3135074 & 2009 & 3036606 \\
\hline 1996 & 1424025 & 2010 & 3255037 \\
\hline 1997 & 752990 & 2013 & 2035934 \\
\hline 1998 & 59271 & 2014 & 1938670 \\
\hline 1999 & 390996 & 2015 & 712751 \\
\hline 2000 & 837191 & 2016 & 545445 \\
\hline 2001 & 3986816 & & \\
\hline
\end{tabular}


Orta Anadolu Bölgesi’nde buğdayda Avrupa Sünesi (Eurygaster maura L. Hemiptera: Scutelleridae)’nin neden olduğu ürün kayıpları ve ekonomik zarar eşiğinin belirlenmesi

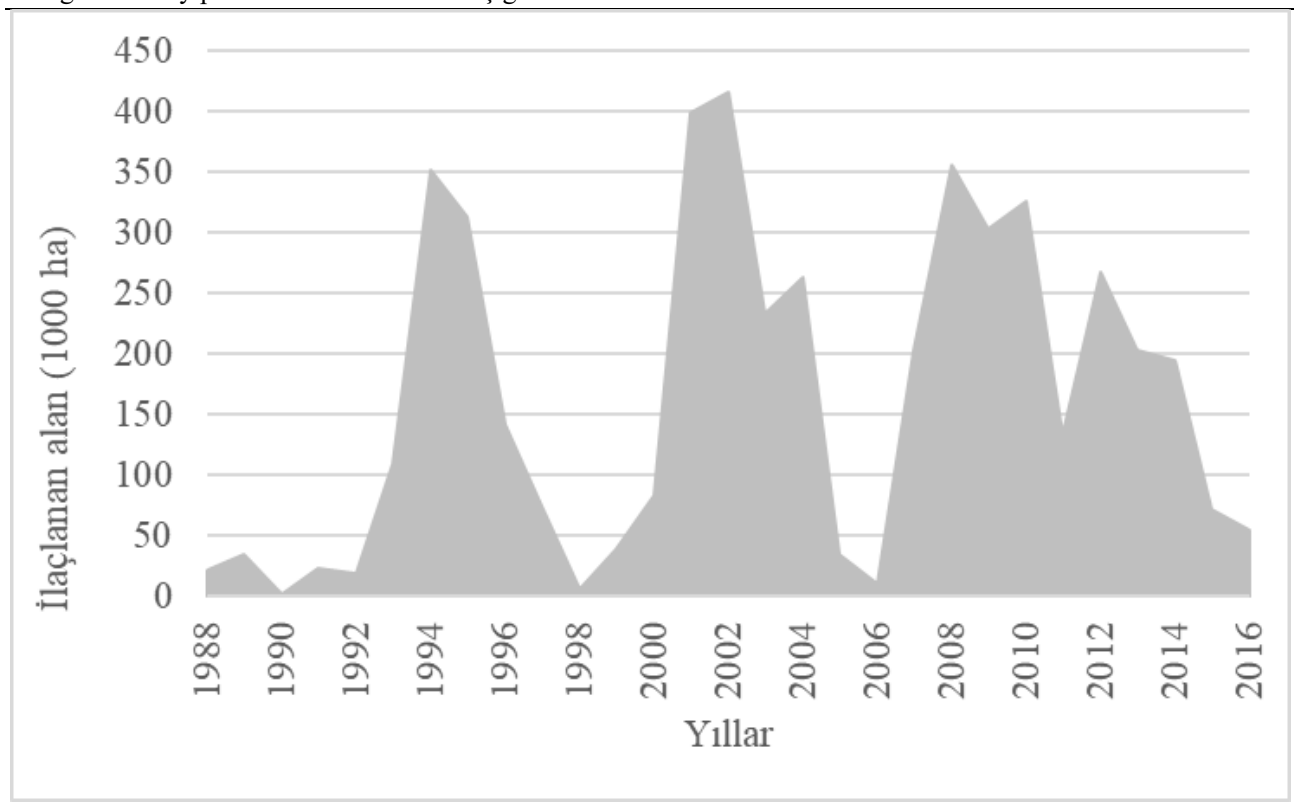

Şekil 2. Orta Anadolu Bölgesinde 1988-2016 yıllarında süneye karşı kimyasal mücadele yapilan alan.

\section{MATERYAL VE METOT}

Çalışmaların ana materyalini Orta Anadolu Bölgesi'nde hakim tür olduğu daha önceden yapılmış çalışmalarla (Wagner 1959, Brown ve Eralp 1962, Dörtbudak ve Koyuncu 1979, Altınayar 1981, Memişoğlu 1985, Lodos ve ark. 1998, Koçak ve Babaroğlu 2005) ortaya konulan Süne (Eurygaster maura), taban alanı $4 \mathrm{~m}^{2}$ olan kafesler (2x2x1.5m), Orta Anadolu Bölgesi illerindeki bulaşık buğday tarlaları, süne tarafından değişik derecelerde zarara uğratılmış (emgili) buğday taneleri, çimlendirme kabinleri oluşturmuştur. Sünenin kışlamış ergin (KE), nimf ve yeni nesil erginlerinin (YNE) meydana getirdikleri zararı belirleyebilmek amaciyla çalışmalar tarla koşullarında kafes ve geniş alan denemeleri olarak yürütülmüştür.

Kafes denemeleri, 1998, 1999 ve 2001 yıllarında Polatlı Tarım İșletmesi Müdürlügüne (Polatlı TİM), 2003 yılında da Bala Tarım İşletmesi Müdürlüguüne (Bala TiM) ait Bezostaya çeşidi ekili buğday tarlalarında yürütülmüştür. Denemeler tesadüf parselleri deneme desenine göre, yıllara göre değişen karakter ve tekrar sayısında yürütülmüștür (Çizelge 3). Kafesler tarlaya yerleştirilmeden önce denemelerin yürütüldügü buğday tarlasında sürveyler yapılarak süne ve kımıl ile bulaşık olmadığı belirlendikten sonra, kafesler (rezerv ve deneme kafesleri) süne inişleri başlamadan önce söz konusu alanlara kurulmuştur

Denemelerin kurulduğu buğday alanlarını etkileyen kışlaklardaki süne inişleri, ilkbaharda günlük maksimum sıcaklık $10^{\circ} \mathrm{C}$ 'nin üzerine çıktığında başlamak üzere 
kışlaktaki ergin popülasyonunun \%90'ının inişi tamamlamasına kadar geçen sürede içerisinde 1'er gün ara ile sayımlar yapılarak takip edilmiştir. Kışlaktaki sayımlar; kışlak bitki örtüsü meşe, çam gibi bitkiler ise yere dökülmüş yaprakları altındaki bireylerin sayısını belirlemek için $1 / 16 \mathrm{~m}^{2}$ lik $(25 \times 25 \mathrm{~cm})$ çerçevelerle 16 adet, bitki örtüsü kirpi-geven, kirpi otu ve kekik bitkileri olması durumunda sayımlar $\mathrm{m}^{2}$ 'ye karşılık gelen bitki adetleri dikkate alınarak yapılmıştır (Dörtbudak et al. 1991).

Kışlamış erginler, kışlaklardan inişlerin başlaması ve belli bir orana (\%20-30) ulaşmasıyla birlikte Orta Anadolu'nun farklı kışlaklarından (Aksaray, Haymana, Polatl1, Kırıkkale) toplanarak, deneme kafeslerinin yanında kurulan rezerv kafeslere konulmuştur. Kışlaktaki kışlamış ergin popülasyonunun \%90'ının ovaya inmesiyle birlikte canlı erkek ve dişi bireyler seçilerek, farklı nimf yoğunluğu elde edebilmek için farklı sayılarda $\left(0.5\right.$ adet $\mathrm{m}^{-2}, 0.75$ adet $\mathrm{m}^{-2}, 1.0$ adet $\mathrm{m}^{-2}, 1.25$ adet m-2 1.5 adet $\mathrm{m}^{-2}$ ) kafeslere aktarılmışlardır.

Geniş alan çalışmaları için Orta Anadolu Bölgesi illerinde (Kurşehir, Aksaray, Konya, Ankara) yer alan farklı kışlamış ergin yoğunlukları saptanan yaklaşık 10 dekarlık buğday tarlaları deneme amacıyla seçilmiştir. Kışlaklardan inişlerin \%090'a ulaşmasıyla birlikte söz konusu tarlalarda sürveyler yapılarak süne yoğunlukları belirlenmiştir. Kontrol amacıyla, seçilen tarlalardan yaklaşık 2 da'lık kısmı süne mücadelesinde ruhsatlı bir insektisit ile insektisitin etki süresi de dikkate alınarak hasat sonuna kadar ilaçlanmıştır. 
Orta Anadolu Bölgesi'nde buğdayda Avrupa Sünesi (Eurygaster maura L. Hemiptera: Scutelleridae)'nin neden olduğu ürün kayıpları ve ekonomik zarar eşiğinin belirlenmesi

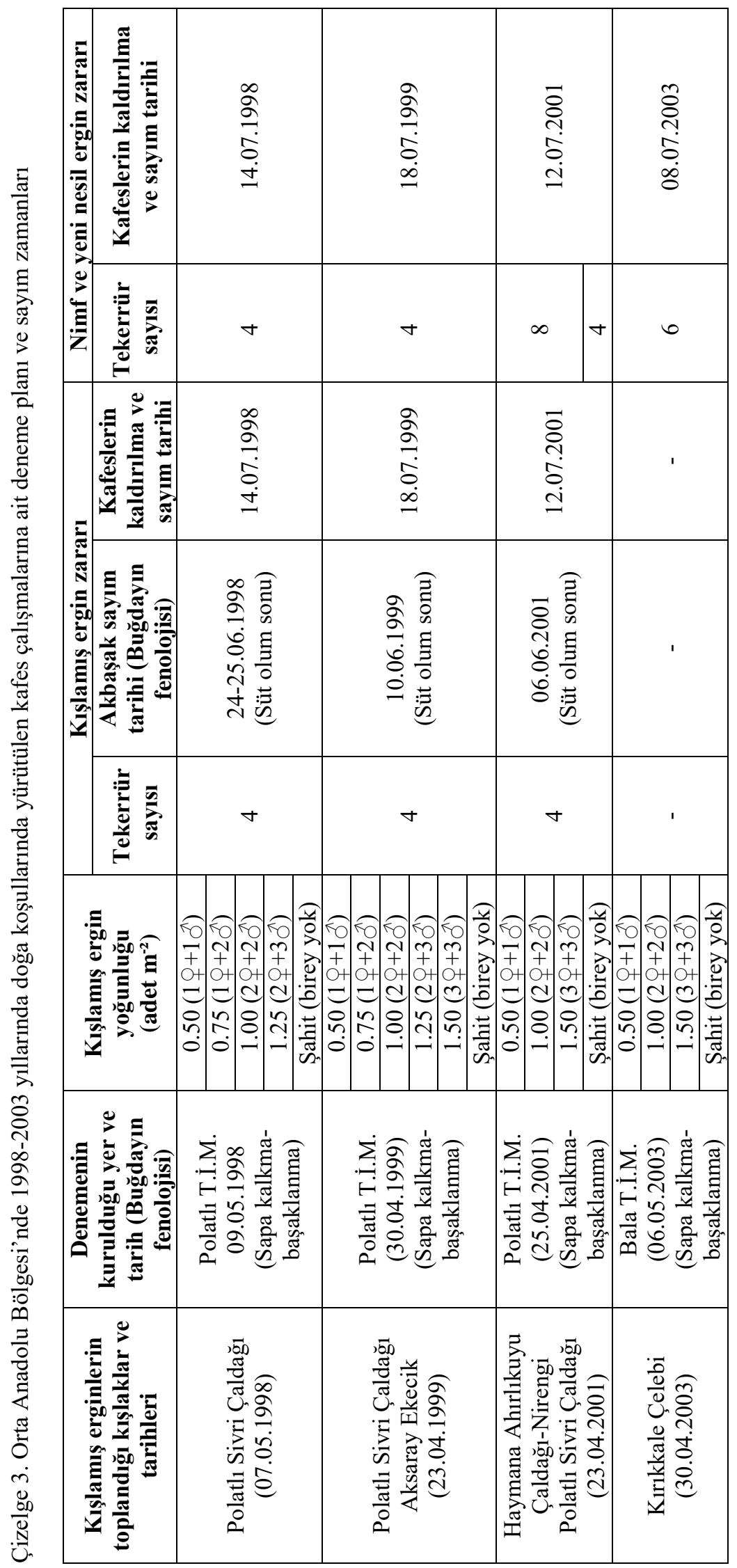


Özkan M., Babaroğlu N. E., Gökdoğan A., Kan M. ve Koçak E., Bitki Koruma Bülteni, 57 (2), 2017

Çalışma süresince, hem kafes ve hem de geniş alan denemelerinin yürütüldüğü Tarım İşletmesine ait meteoroloji istasyonlarından iklim verileri temin edilmiş, buğdaya ait fenolojik kayitlar da tutulmuştur.

Çalı̧̧ma, Süne ergin ve nimflerinin farklı fenolojik dönemdeki buğdayda beslenmeleri sonucu meydana getirdiği 3 tip zararı da; kurtboğazı, akbaşak ve tanede emgi zararını belirleyecek şekilde kurgulanmıştır. Bu amaçla:

\section{Kurtboğazı Zararı}

$\mathrm{Bu}$ amaç için, 1998, 1999 ve 2001 yıllarında kışlaktaki ergin popülasyonunun \%90'ının ovaya indiği tarihlerde denemelerin kurulduğu tarlalarda yapılan gözlemlerde buğday fenolojik olarak kurtboğazı zararının oluştuğu kardeşlenme dönemini tamamladığından, kurtboğazı zararına yönelik kafes ve geniş alan denemeleri kurulamamıştır.

\section{Akbaşak Zararı}

\subsection{Kafes denemeleri}

Akbaşak zararını belirleme çalışmaları, 1998, 1999 ve 2001 yıllarında yürütülmüştür. Kışlaktaki kışlamış ergin popülasyonunun \%90'ının ovaya inmesiyle birlikte farklı KE yoğunluklarında oluşturulan kafeslerin $4 \mathrm{~m}^{2}$ 'lik alanındaki sağlam başak ve akbaşaklar, buğdayın süt olum sonunda ve hasat aşamasında olmak üzere iki kez sayılmıştır. Her bir kafesteki akbaşak sayısı toplam başak sayısına oranlanarak akbaşak (\%) zararı belirlenmiştir.

\subsection{Geniş alan çalışmaları}

Akbaşak zararını ortaya koymak amacıyla, geniş alan çalışmaları, 2002 yılında Polatlı Tarım İşletmesi Müdürlüğü'ne ait 3 adet, 2005 yılında Aksaray Koçaş Tarım İşletmesi Müdürlüğü'ne ait 2 adet yaklaşık 10'ar dekarlık, buğday tarlasında yürütülmüştür. $\mathrm{Bu}$ amaç için seçilmiş olan tarlalarda, kışlaktaki kışlamış ergin popülasyonunun \%90'ının ovaya inmesiyle birlikte $1 / 4 \mathrm{~m}^{2}$ 'lik çerçeveler ile her parselde 12 adet (toplam $3 \mathrm{~m}^{2}$ ) sayım yapılarak kışlamış ergin yoğunluğu belirlenmiştir. Söz konusu tarlalarda ayrıca süt olum sonu-sarı olum başında ve hasatta yine $1 / 4 \mathrm{~m}^{2}$ 'lik çerçeveler ile $\mathrm{m}^{2}$ 'deki akbaşak ve başak sayıları da tespit edilmiş, akbaşak sayısı toplam başak sayısına oranlanarak akbaşak (\%) zararı belirlenmiştir.

Akbaşak zararını belirlemek amacıyla kafes ve geniş alan denemelerinden elde edilen değerlere varyans analizi uygulamadan önce, sayılarak elde edilen değerlere karekök, yüzde olarak hesaplanan değerlere de açı transformasyonu yapılmıştır. Varyans analizi uygulanan karakterler arasında farklılık belirlenmiş ise, bu farklılıkların önem derecelerine göre sıralamalarını bulmak için Duncan testinden yararlanılmıştır. Akbaşak zararındaki değişimi açıklayabilmek için çoklu doğrusal regresyon analizi yapılmıştır. 
Orta Anadolu Bölgesi'nde buğdayda Avrupa Sünesi (Eurygaster maura L. Hemiptera: Scutelleridae)’nin neden olduğu ürün kayıpları ve ekonomik zarar eşiğinin belirlenmesi

\section{Tanedeki Emgi Zararı}

\subsection{Kantite (nicelik) yönünden}

\subsubsection{Kafes denemeleri}

Kışlaktaki kışlamış ergin popülasyonunun \%90'ının ovaya inmesiyle birlikte farklı KE yoğunluklarında oluşturulan kafesler hasat döneminde kaldırılarak öncelikle her bir kafesteki nimf+yeni nesil ergin yoğunluğu belirlenmiştir. Daha sonra her kafesteki $\left(4 \mathrm{~m}^{2}\right)$ buğdaylar orakla hasat edilerek laboratuvara getirilmiştir. Laboratuvara getirilen demetler her bir kafes için sayılmış ve $4 \mathrm{~m}^{2}$ 'lik alandaki toplam başak sayısı bulunmuştur. Bu toplam başak sayısından 100 adet başak tesadüfen çekilerek, bunların her birinin tane sayısı ve başaktaki tüm tanelerin toplam ağırlığı ile 1000 tane ağırlığı bulunmuştur.

\subsubsection{Genis alan denemeleri}

Geniş alan çalışmaları için Orta Anadolu Bölgesi illerinde (Kırşehir, Aksaray, Konya, Ankara) yer alan ve farklı kışlamış ergin yoğunlukları saptanan buğday ekilişleri (8-10 da) seçilmiştir. Seçilen bu tarlalardan 2.5 dekarlık kısmı ilaçlanarak kontrol amacıyla ayrılmışlardır. Kontrol olarak seçilen tarlalar, sünelerin kışlaktan ovaya inişinin başlamasıyla birlikte hasada kadar kullanılan ilacın etki süresi de dikkate alınarak süne mücadelesinde ruhsatlı bir insektisit ile ilaçlanmıştır. Belirlenmiş bu tarlalarda $1 / 4 \mathrm{~m}^{2}$ 'lik çerçeveler ile $\mathrm{m}^{2}$ deki kışlamış ergin ve nimf+yeni nesil ergin yoğunluğu, $\mathrm{m}^{2}$ 'deki başak sayıları belirlenmiştir. Hasat aşamasında seçilmiş tarlalardan buğday başakları (her tarla için en az 400 adet başak) laboratuvara getirilmiş, başaktaki tane sayısı ile başaktaki tüm tanelerin toplam ağırlığı ve 1000 tane ağırlı̆̆

Süne nimf ve yeni nesil erginlerinin buğdayda oluşturdukları verim kaybını ortaya koymak için, buğdayın tane verimini belirleyen temel öğeler; $\mathrm{m}^{2}$ deki başak, başaktaki tane sayılarına ve tane ağırlığına (Fonseca and Patterson 1968, Bhatt 1972, Sidwell et al. 1976, Gebeyehou et al. 1982, Demir ve Tosun 1991, Kurtok ve Çölkesen 1985, Puri et al. 1982) süne (nimf+yeni nesil ergin) yoğunluğunun etkisini belirlemek amaciyla hem kafes ve hem de geniş alan elde edilen verim öğeleri değerleri ile nimf+yeni nesil ergin yoğunluğu arasındaki korelasyona bakılmıştır.

\subsection{Kalite (nitelik) yönünden}

\subsubsection{Kafes denemeleri}

Nitelik yönünden zararı ortaya koyabilmek amacıyla belirlenen verilere; $\mathrm{m}^{2}$ 'deki başak, başaktaki tane sayıları ve tane ağırlığına ek olarak ayrıca bu parsellerdeki (kafeslerdeki) buğday tanelerinden elde edilen paçal örneklerden 10x100 tane ayrilarak o kafesteki nimf ve yeni nesil erginlerin tanede beslenmeleri sonucu oluşan emgi oranı (\%) bulunmuştur. Buğdayın fizikokimyasal (teknolojik) özelliklerini bozan kabul edilebilir üst emgi oranını oluşturan nimf+yeni nesil ergin sayısını belirleyebilmek amacıyla ikili lojistik regresyon analizinden yararlanılmıştır. 
Lojistik regresyon ile oluşturulan modelde emgi oranı (\%) bağımlı değişken olarak alınmış, emgi oranı kabul edilebilir emgi sınırının $(\% 2 ; 3 ; 3.5 ; 4 ; 5)$ altında ise "0", üzerinde ise "1" değerini alarak iki gruba atanmıştır. Atama işlemi bittikten sonra elde edilen denklem 1şı̆̆ı altında uygulamada geçerli olacak skala değerleri hazırlanmıştır. Modelde yer alan bağımsız değişkenlerin tümü sürekli değişken olduğundan herhangi bir kodlama yapılmamıştır. Çalışmada elde edilen verilere herhangi bir işlem de (veri atma, dönüştürme) yapılmamıştır.

\subsubsection{Geniş alan denemeleri}

Kafes denemelerinden elde edilen verilerle belirlenen kabul edilebilir üst emgi oranını oluşturan nimf sayılarının tarla koşullarında da aynı sonucu verip vermediğini belirlemek amaciyla, Orta Anadolu Bölgesi illeri; Ankara, Aksaray, Konya ve Kırşehir buğday ekim alanlarında farklı kışlamış ergin yoğunlukları saptanan 8-10 dekarlık buğday tarlaları seçilmiş, seçilen bu tarlalardan bir kısmı (2.5 da) ilaçlanarak kontrol amacıyla ayrılmışlardır. Kontrol olarak ayrılan kısımlar, sünelerin kışlaktan ovaya inişinin başlamasıyla birlikte hasada kadar kullanılan ilacın etki süresi de dikkate alınarak süne mücadelesinde ruhsatlı bir insektisit ile ilaçlanmıştır. Belirlenmiş bu tarlalarda $1 / 4 \mathrm{~m}^{2}$ 'lik çerçeveler ile $\mathrm{m}^{2}$ deki kışlamış ergin ve nimf+yeni nesil ergin yoğunluğu, $\mathrm{m}^{2}$ 'deki başak sayıları belirlenmiştir. Hasat aşamasında her tarla için en az 400 adet başak laboratuvara getirilmiş, başaktaki tane sayısı saptanmış, bu örneklerden 10x100 tane ayrılarak, gözle incelenerek emgili taneler ayrılmıştır. Emgili tane sayısının toplam tane sayısına oranı hesaplanarak o tarladaki ortalama emgi oranı (\%) da bulunmuştur.

Tarlalardan elde edilen gerçek değerler ile $\left(\mathrm{m}^{2}\right.$ ' deki nimf + yeni nesil ergin yoğunluğu ile başak sayısı, başaktaki tane sayısı emgi oranı) kafes denemelerinden elde edilen verilerle belirlenen skala değerleri karşılaştırılmıştır.

\section{4. Çimlenmeye Etki}

Çimlendirme ve sürme denemeleri Uluslararası Tohum Test Birliğinin (Anonymous 2004) metot ve uygulamaları doğrultusunda Tohum Tescil ve Sertifikasyon Merkez Müdürlügü̈ne ait $20 \pm 1{ }^{\circ} \mathrm{C}$ ve $\% 65 \pm 5$ nem koşullarına sahip çimlendirme kabinlerinde yürütülmüş, çalışmalar Özkan ve ark. (2014) tarafından yayınlanmıştır.

\section{SONUÇLAR VE TARTIŞMA}

\section{Kurtboğazı Zararı}

Orta Anadolu Bölgesi'nde çalışmaların yürütüldüğü her 3 yılda da kışlaklarda süne hareketlenmeleri nisan ayının 2. yarısında başlamış inişler nisan sonu-mayıs başında tamamlanmıştır. Süne inişlerinin tamamlandığ tarihlerde buğdayın fenolojik olarak sapa kalkma-başaklanma döneminde olduğu da belirlenmiştir (Çizelge 3).

Denemelerin yürütüldüğü tüm yıllarda, sünenin kışlaktan ovaya göçü başlayıp ve göç oranı \%90' a ulaştığında (nisan sonu - mayıs başı), buğday fenolojik olarak 
Orta Anadolu Bölgesi’nde buğdayda Avrupa Sünesi (Eurygaster maura L. Hemiptera: Scutelleridae)’nin neden olduğu ürün kayıpları ve ekonomik zarar eşiğinin belirlenmesi

kardeşlenmeyi tamamladığından; kurtboğazı zararını belirleyebilmek için denemeler kurulamamış ve çalışmanın bu bölümü gerçekleştirilememiştir (Çizelge 3).

Söz konusu durum daha önce Bölgemizde yapılan başka bir çalışmada da karşımıza çıkmaktadır. Memişoğlu (1985), E. maura'nın ilkbaharda havaların 1sınması ile kışlaktan göç ettiği tarihlerde buğdayın sapa kalkma ve başaklanma döneminde olduğunu bildirmektedir. Ayrıca 1988 yılından itibaren Orta Anadolu Bölgesi süne mücadelesi çalışmaları çerçevesinde yürütülen sünenin kışlaktan ovaya iniş seyrinin takibini gösteren IIlkbahar Kışlak Sürveyi Cetvelleri incelendiğinde; Bölgemizde inişlerin olduğu tarihlerde buğdayın fenolojik olarak kardeşlenmeyi tamamlamış ve sapa kalkma döneminde bulunduğu, bu nedenle kışlamış erginlerin başak sapında, nadiren beslenebildiği kurtboğazı zararının da nadiren görüldüğü belirlenmiştir.

Yüksel (1968), Güneydoğu Anadolu Bölgesi’nde yaptığı çalışmalarda sünenin mart ortası-nisan başında kışlaktan göç ettiğini, bu zamanda buğdayların 8-10 cm boyda ve 6-7 yapraklı olduklarını bildirmektedir. Aynı araştırmacı bazı yıllar yüksek süne yoğunluğu (35-53 adet $\mathrm{m}^{-2}$ ) olan tarlalarda \%90-98 oranında kurtboğazı zararının oluştuğunu, $\mathrm{m}^{2}$ 'de 2,6 ve 10 adet kışlamış ergin bulunan kafeslerde sırasıyla \%14, 30.8 ve 51.7 oranında kurtboğazı zararının oluștuğunu, tarla koșullarında $2-3.2$ adet $\mathrm{m}^{-2}$ kışlamış ergin bulunan tarlalarda \%17-25 oranında kurtboğazı zararının olduğunu bildirmektedir. Yüksel (1968), Lodos (1952)'a atfen Diyarbakır'da 1951 yılında \%13; 1952 yılında da \%16.6 oranında kurtboğazı zararının olduğunu bildirmektedir. Yine aynı bölgede Kılıç ve ark. (1973) ovaya göçün yıllık iklim koşullarına bağlı olarak 4-28 Nisan tarihlerine rastladığını bildirmektedirler. Aynı araştırmacılar Güneydoğu Anadolu Bölgesi'nde 1970 yılında yaptıkları çalışmada $\mathrm{m}^{2}$ 'de 0.4 adet kışlamış erginin bulunması durumunda \%5.7; $1.0-1.5$ adet bulunduğunda $\% 8.5 ; 1.6-2.0$ adet bulunduğunda $\% 10.9$ ve $2.1-2.3$ adet bulunduğunda ise $\% 13.7$ oranında kurtboğazı zararının ortaya çıktığını bildirmektedirler.

Tayakısı ve ark. (1973) Adana ilinde sünenin ovaya inişinde buğdayın tamamen sapa kalkma döneminde olmaları sebebiyle kurtboğazı zararının öneminin bulunmadığını bildirmektedirler.

Canhilal et al. (2005), sünenin kışlaktan ovaya göçünü tamamladığı tarihlerde buğdayın 10-15 cm boyda olduğu ve Güneydoğu Anadolu Bölgesi'nde kurtboğazı zararının görülmediğini bildirmektedirler. 


\section{Akbaşak Zararı}

\subsection{Kafes denemeleri}

Akbaşak zararını ortaya koymak amacıyla, 1998, 1999 ve 2001 yıllarında yapılan kafes çalışmalarından elde edilen $\mathrm{m}^{2}$ 'deki ortalama başak ve akbaşak sayıları ile akbaşak zarar oranı Şekil 3 ve Çizelge 4'te verilmektedir.

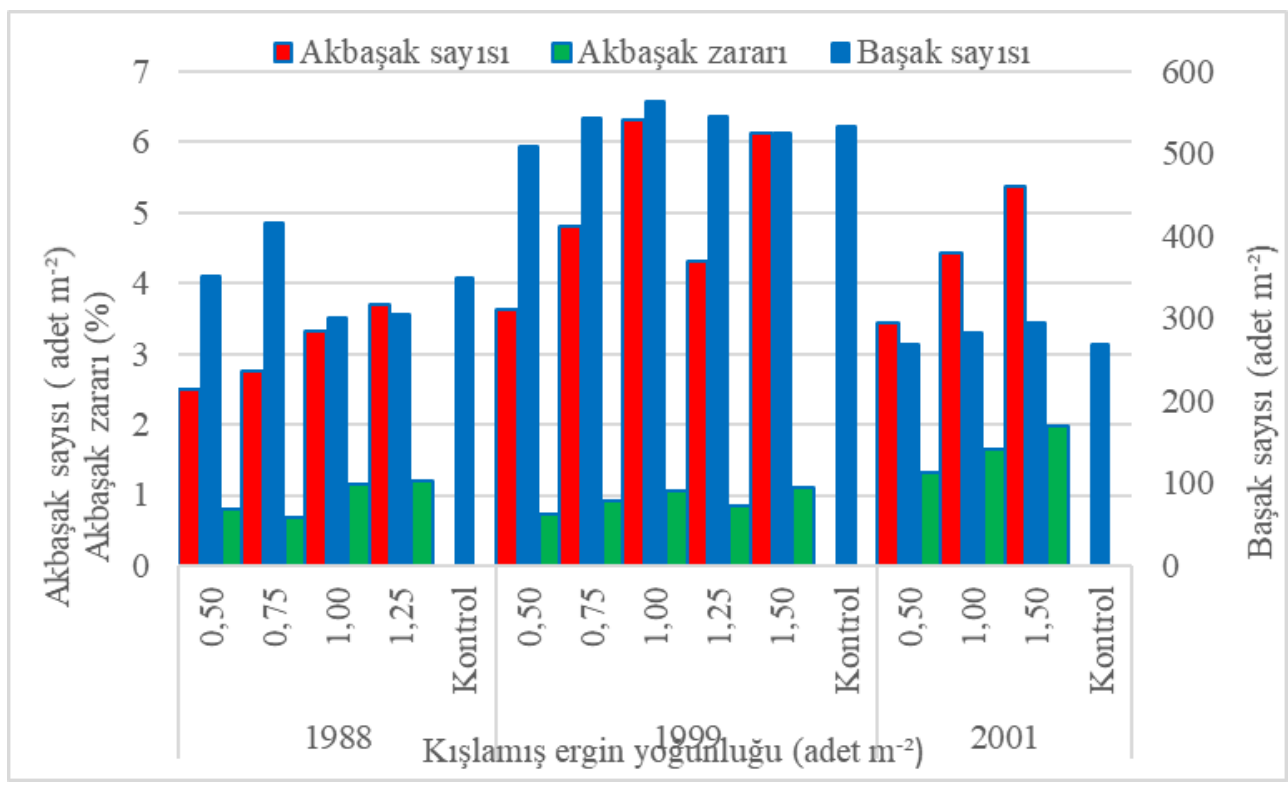

Şekil 3. İç Anadolu Bölgesi’nde 1998, 1999 ve 2001 yıllarında gerçekleştirilen kafes denemelerinde farklı kışlamış ergin yoğunluklarındaki $\mathrm{m}^{2}$ deki ortalama başak, akbaşak sayıları ile akbaşak zararı.

Çizelge 4 ve Şekil 3 birlikte incelendiğinde; ortalama akbaşak sayısının farklı yıl ve kışlamış ergin yoğunluklarında $\mathrm{m}^{2}$ 'de 2.50 ile 6.13 adet arasında değiştiği, varyans analizi sonucunda akbaşak sayısının farklı yıllardaki kışlamış ergin yoğunluğuna bağlı olarak değişmediği $(\mathrm{F}=0.358 ; \mathrm{p}=0.922)$ ve yine zararlının farklı yıllarda oluşturduğu akbaşak sayıları arasında da istatistiksel açıdan farkın olmadığ $(\mathrm{F}=2.748 ; \mathrm{p}=0.075)$ tespit edilmiştir. 
Orta Anadolu Bölgesi’nde buğdayda Avrupa Sünesi (Eurygaster maura L. Hemiptera: Scutelleridae)’nin neden olduğu ürün kayıpları ve ekonomik zarar eşiğinin belirlenmesi

Çizelge 3. İç Anadolu Bölgesi'nde 1998, 1999 ve 2001 yıllarında gerçekleștirilen kafes denemelerinde farklı kışlamış ergin yoğunluklarındaki $\mathrm{m}^{2}$ deki ortalama başak, akbaşak sayıları ile akbaşak zararı.

\begin{tabular}{|c|c|c|c|c|}
\hline Yillar & $\begin{array}{c}\text { Kışlamış ergin } \\
\text { yoğunluğu } \\
\left(\text { adet } \mathbf{m}^{-2}\right)\end{array}$ & $\begin{array}{c}\text { Başak sayısı } \\
\text { (adet } \mathbf{m}^{-2} \text { ) } \\
\text { Ort. } \pm \text { St. hata }\end{array}$ & $\begin{array}{c}\begin{array}{c}\text { Akbaşak sayısı } \\
\left(\text { adet } \mathbf{m}^{-2}\right) \\
\text { Ort. } \pm \text { St. hata }\end{array} \\
\end{array}$ & $\begin{array}{c}\text { Akbaşak zararı } \\
(\%) \\
\text { Ort. } \pm \text { St. hata }\end{array}$ \\
\hline \multirow{6}{*}{$\stackrel{\infty}{\mathscr{g}}$} & 0.50 & $350.94 \pm 53.27$ & $2.50 \pm 0.23$ & $0.81 \pm 0.21$ \\
\hline & 0.75 & $415.38 \pm 71.43$ & $2.75 \pm 0.37$ & $0.68 \pm 0.04$ \\
\hline & 1.00 & $301.88 \pm 47.91$ & $3.31 \pm 0.30$ & $1.16 \pm 0.14$ \\
\hline & 1.25 & $305.13 \pm 16.95$ & $3.69 \pm 0.45$ & $1.20 \pm 0.11$ \\
\hline & Kontrol & $349.75 \pm 45.74$ & $0.00 \pm 0.00$ & $0.00 \pm 0.00$ \\
\hline & Yıl ortalaması & $344.61 \pm 22.08$ & $2.45 \pm 0.32$ & $0.77 \pm 0.11$ \\
\hline \multirow{7}{*}{ g) } & 0.50 & $508.19 \pm 23.81$ & $3.63 \pm 1.39$ & $0.72 \pm 0.28$ \\
\hline & 0.75 & $543.06 \pm 55.19$ & $4.81 \pm 1.15$ & $0.92 \pm 0.16$ \\
\hline & 1.00 & $563.75 \pm 50.01$ & $4.69 \pm 0.69$ & $1.07 \pm 0.26$ \\
\hline & 1.25 & $545.56 \pm 47.48$ & $5.94 \pm 0.94$ & $0.84 \pm 0.31$ \\
\hline & 1.50 & $524.63 \pm 7.82$ & $6.13 \pm 1.73$ & $1.18 \pm 0.27$ \\
\hline & Kontrol & $532.69 \pm 33.31$ & $0.00 \pm 0.00$ & $0.00 \pm 0.00$ \\
\hline & Yıl ortalaması & $536.31 \pm 14.85$ & $4.20 \pm 0.64$ & $0.79 \pm 0.12$ \\
\hline \multirow{5}{*}{ 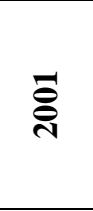 } & 0.50 & $269.56 \pm 22.25$ & $3.44 \pm 0.36$ & $1.32 \pm 0.21$ \\
\hline & 1.00 & $282.75 \pm 18.39$ & $4.44 \pm 1.37$ & $1.66 \pm 0.56$ \\
\hline & 1.50 & $295.31 \pm 35.95$ & $5.38 \pm 1.02$ & $1.89 \pm 0.36$ \\
\hline & Kontrol & $269.00 \pm 14.73$ & $0.00 \pm 0.00$ & $0.00 \pm 0.00$ \\
\hline & Yıl ortalaması & $279.16 \pm 11.18$ & $3.31 \pm 0.65$ & $1.21 \pm 0.25$ \\
\hline \multicolumn{2}{|c|}{ GENEL ORTALAMA } & $403.84 \pm 17.44$ & $3.38 \pm 0.34$ & $0.90 \pm 0.09$ \\
\hline
\end{tabular}

Akbaşak sayılarındaki farklılıkların $\mathrm{m}^{2}$ 'deki kışlamış ergin yoğunluklarına göre değiştiği belirlenmiştir $(\mathrm{F}=14.171 ; \mathrm{p}=0.000)$. Çoklu karşılaştırma sonucunda kışlamış ergin yoğunluğu 1.50 adet $\mathrm{m}^{-2}$ karakteri birinci (a); 1.25 ve 1.00 adet m-2 karakterleri ikinci (ab); 0.75 ve 0.50 adet $\mathrm{m}^{-2}$ karakterleri üçüncü (b) ve kontrolde dördüncü (c) grubu oluşturmuştur (Çizelge 5). Kışlamış ergin yoğunlukları ile $\mathrm{m}^{2}$ 'deki akbaşak sayısı arasında pozitif bir ilişkinin olduğu $(\mathrm{r}=0.734 ; \mathrm{r} 2=0.539$; $\mathrm{p}=0.00), \mathrm{m}^{2}$ 'deki kışlamış ergin yoğunluğunun artmasına bağlı olarak $\mathrm{m}^{2}$ 'deki akbaşak sayısında da artışın olacağı ortaya konulmuştur (Şekil 4). 
Özkan M., Babaroğlu N. E., Gökdoğan A., Kan M. ve Koçak E., Bitki Koruma Bülteni, 57 (2), 2017

Çizelge 4. Kafes denemelerinde farklı kışlamış ergin yoğunluklarında $\mathrm{m}^{2}$ deki ortalama akbaşak sayıları ile akbaşak zararı.

\begin{tabular}{|c|c|c|c|}
\hline $\begin{array}{c}\text { Kışlamış ergin } \\
\left.\text { yoğunluğu (adet } \mathbf{m}^{-2}\right)\end{array}$ & $\begin{array}{c}\text { Tekerrür } \\
\text { sayısı }\end{array}$ & $\begin{array}{l}\text { Akbaşak sayısı (adet } \mathbf{m}^{-2} \text { ) } \\
\text { Ortalama } \pm \text { Standart hata }\end{array}$ & $\begin{array}{c}\text { Akbaşak zararı (\%) } \\
\text { Ortalama } \pm \text { Standart } \\
\text { hata }\end{array}$ \\
\hline 0.50 & 12 & $\begin{array}{c}3.19 \pm 0.46 \mathbf{b}^{*} \\
(1.75-7.75) \\
\end{array}$ & $\begin{array}{c}0.95 \pm 0.17 \mathbf{b} \\
(0.61-1.37) \\
\end{array}$ \\
\hline 0.75 & 8 & $\begin{array}{c}3.78 \pm 0.68 \mathbf{b} \\
(2.00-8.25) \\
\end{array}$ & $\begin{array}{c}0.80 \pm 0.09 \mathbf{b} \\
(0.36-1.70)\end{array}$ \\
\hline 1.00 & 12 & $\begin{array}{c}4.14 \pm 0.50 \text { ab } \\
(0.75-6.75) \\
\end{array}$ & $\begin{array}{c}1.21 \pm 0.11 \mathbf{a b} \\
(0.49-1.78) \\
\end{array}$ \\
\hline 1.25 & 8 & $\begin{array}{c}4.81 \pm 0.48 \mathbf{a b} \\
(3.00-6.50)\end{array}$ & $\begin{array}{c}1.16 \pm 0.24 \mathbf{a b} \\
(0.24-2.66)\end{array}$ \\
\hline 1.50 & 8 & $\begin{array}{l}5.75 \pm 0.94 \mathbf{a} \\
(2.25-10.50)\end{array}$ & $\begin{array}{l}1.53 \pm 0.28 \mathbf{a} \\
(0.41-2.94)\end{array}$ \\
\hline Şahit & 12 & $\begin{array}{l}0.00 \pm 0.00 \mathbf{c} \\
(0.00-0.00)\end{array}$ & $\begin{array}{l}0.00 \pm 0.00 \mathbf{c} \\
(0.00-0.00)\end{array}$ \\
\hline
\end{tabular}

* Aynı sütundaki farklı küçük harf taşıyan değerler istatistiksel olarak birbirinden farklıdır.

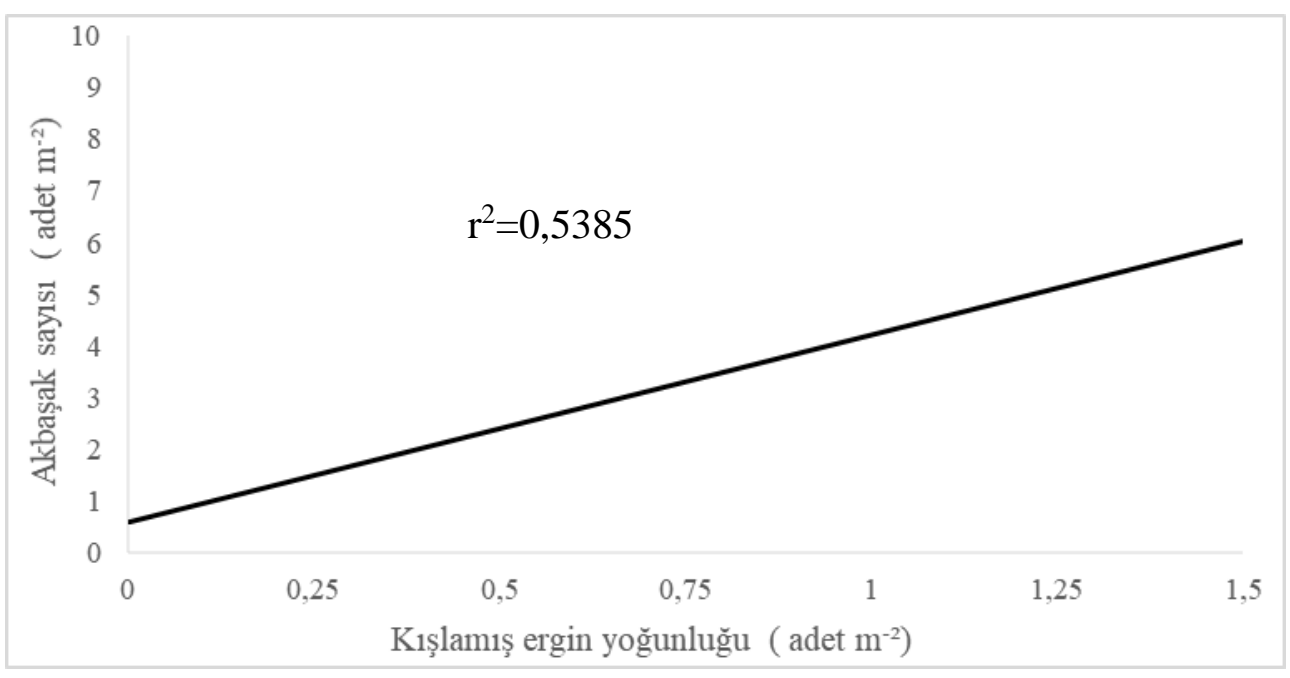

Şekil 4. Kafes denemelerinden elde edilen farklı kışlamış ergin yoğunlukları ile akbaşak sayılarına ait regresyon doğrusu.

Aynı çalışmada akbaşak zararının farklı yıl ve kışlamış ergin yoğunluklarında ortalama \%0.68-1.89 oranında olduğu belirlenmiştir (Çizelge 4). Söz konusu zararın farklı yıllardaki kışlamış ergin yoğunluğuna bağlı olarak değişmediği $(\mathrm{F}=0.703$; $\mathrm{p}=0.670)$, ancak akbaşak zararının yıllara $(\mathrm{F}=4.700 ; \mathrm{p}=0.014)$ ve kışlamış ergin yoğunluklarına göre farklılıklar gösterdiği $(\mathrm{F}=36.698 ; \mathrm{p}=0.000)$ belirlenmiştir. 
Orta Anadolu Bölgesi'nde buğdayda Avrupa Sünesi (Eurygaster maura L. Hemiptera: Scutelleridae)’nin neden olduğu ürün kayıpları ve ekonomik zarar eşiğinin belirlenmesi

Çalışmanın yürütüldüğü yıllardaki en yüksek akbaşak zararı \%1.21 ile 2001 yılında (a grubu) tespit edildiği, 1998 ve 1999 yıllarında sırasıyla \%0.77 ve \%0.79 oranında zarar (b grubu) meydana geldiği, zarar oranındaki bu farklılığın o yılın iklim koşullarına göre değişkenlik gösterebildiği belirlenmiştir (Çizelge 4). Nitekim 19971998 üretim sezonunda özellikle ilkbahar aylarında mevsim normallerinin üzerinde alınan yağış (ekilişin aldığı toplam yağış miktarı $327.4 \mathrm{~mm}$ ) sonucu ${ }^{2}$ 'deki başak sayısının (344 adet) fazla olması sonucunda akbaşak zararı düşük düzeylerde ortaya çıkmıştır. Aynı durum 1998-1999 üretim sezonunda da yaşanmış (ekilişin aldığı toplam yağış miktarı $286.7 \mathrm{~mm}$ ) ve $\mathrm{m}^{2}$ 'deki başak sayısı (536 adet) fazla olmuş; bunun sonucunda yine akbaşak zararı düşük oranlarda oluşmuştur. $\mathrm{m}^{2}$ 'deki başak sayısının (279 adet) az olduğu 2000-2001 üretim sezonunda ise ekilişin aldığı toplam yağış miktarının $145.4 \mathrm{~mm}$ olduğu dikkati çekmekte, bunun sonucunda da akbaşak zararının geçmiş yıllara göre oldukça yüksek düzeylerde seyrettiği görülmektedir (Çizelge 6). Yağış olmayan ve kurak geçen yıllarda $\mathrm{m}^{2}$ 'de bitki sayısı daha az olacağından akbaşak zararının daha yüksek oranlarda olduğu ortaya konmuştur ( $\mathrm{r}=-$ 25.20; $\mathrm{r}^{2}=6.35 ; \mathrm{p}=0.026$ ).

Çizelge 5. Denemelerin yürütüldüğü Tarım İşletme Müdürlüklerinin çalışmalar süresince aylık toplam yağış ve ortalama sıcaklık değerleri.

\begin{tabular}{|c|c|c|c|c|c|c|c|c|c|c|}
\hline \multirow{3}{*}{$\begin{array}{l}\text { Denemelerin yürütüldüğ̈̈ü } \\
\text { işletme }\end{array}$} & \multicolumn{10}{|c|}{ Aylar } \\
\hline & 9 & 10 & 11 & 12 & 1 & 2 & 3 & 4 & 5 & 6 \\
\hline & \multicolumn{10}{|c|}{ POLATLI TARIM İŞLETMESI MÜDÜRLÜĞÜ } \\
\hline Üretim sezonu & \multicolumn{4}{|c|}{1997} & \multicolumn{6}{|c|}{1998} \\
\hline Aylık toplam yağıș (mm) & 3.2 & 56.9 & 23.9 & 40.5 & 13.6 & 27.4 & 41.9 & 37.2 & 76.9 & 5.9 \\
\hline Aylık ortalama sıcaklık $\left({ }^{\circ} \mathrm{C}\right)$ & 15.3 & 11.7 & 9.7 & 5.4 & 6.6 & 9.5 & 7.7 & 11.3 & 13.5 & 15.6 \\
\hline Üretim sezonu & \multicolumn{4}{|c|}{1998} & \multicolumn{6}{|c|}{1999} \\
\hline Aylık toplam yağıș (mm) & 5.7 & 23.2 & 30.7 & 58.0 & 15.2 & 34.7 & 45.1 & 28.7 & 0.0 & 45.4 \\
\hline Aylık ortalama sıcaklık $\left({ }^{\circ} \mathrm{C}\right)$ & 15.6 & 13.8 & 9.0 & 7.1 & 5.4 & 4.7 & 10.0 & 11.7 & 15.6 & 13.5 \\
\hline Üretim sezonu & \multicolumn{4}{|c|}{2000} & \multicolumn{6}{|c|}{2001} \\
\hline Aylık toplam yağıș (mm) & 5.9 & 21.0 & 7.6 & 26.2 & 1.1 & 12.6 & 22.1 & 17.5 & 31.4 & 0.0 \\
\hline Aylık ortalama sıcaklık $\left({ }^{\circ} \mathrm{C}\right)$ & 15.9 & & & 9.2 & 2.9 & 3.0 & 10.8 & 12.2 & 10.8 & 22.2 \\
\hline Üretim sezonu & \multicolumn{4}{|c|}{2001} & \multicolumn{6}{|c|}{2002} \\
\hline Aylık toplam yağış (mm) & 8.4 & 0.0 & 56.4 & 87.4 & 48.0 & 11.5 & 21.9 & 45.2 & 16.3 & 17.7 \\
\hline Aylık ortalama sıcaklık $\left({ }^{\circ} \mathrm{C}\right)$ & 20.7 & 13.2 & 6.5 & 2.2 & 0.0 & 3.1 & 8.0 & 10.4 & 16.1 & 20.2 \\
\hline $\begin{array}{l}\text { Denemelerin yürütülddüğü } \\
\text { işletme }\end{array}$ & \multicolumn{10}{|c|}{$\begin{array}{c}\begin{array}{c}\text { KOÇAŞ TARIM İŞLETMESİ MÜDÜRLÜĞ̈̈ } \\
\text { (Sulu tarım yapılmaktadır) }\end{array} \\
\end{array}$} \\
\hline Üretim sezonu & \multicolumn{4}{|c|}{2004} & \multicolumn{6}{|c|}{2005} \\
\hline Aylık toplam yağıș (mm) & 0.0 & 2.5 & 77.6 & 11.5 & 32.0 & 17.0 & 30.9 & & 36.0 & 2.0 \\
\hline Aylık ortalama sıcaklık $\left({ }^{\circ} \mathrm{C}\right)$ & & & & & 3.3 & 2.9 & 6.8 & & 16.5 & 20.5 \\
\hline
\end{tabular}




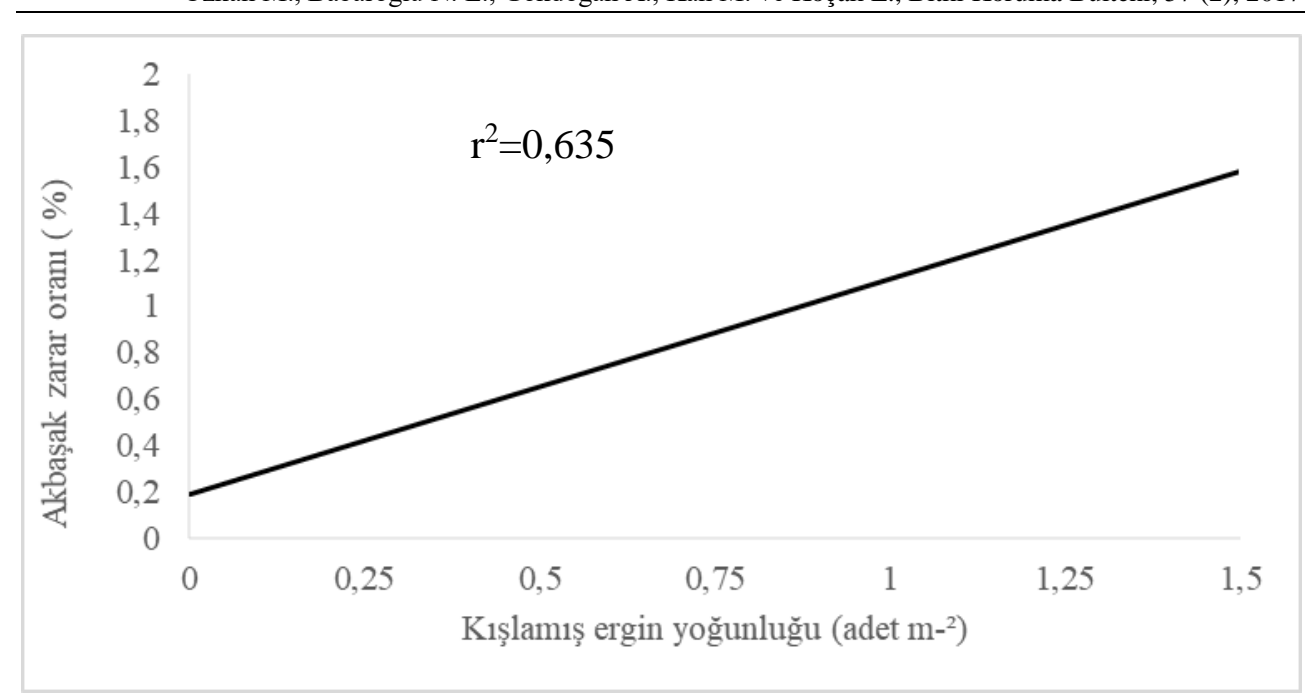

Şekil 5. Kafes denemelerinden elde edilen farklı kışlamış ergin yoğunlukları ile akbaşak zarar oranına ait regresyon doğrusu.

Benzer şekilde Yüksel (1968), Güneydoğu Anadolu Bölgesi'nde kışlamış ergin yoğunluklarına bağlı olarak, yıldan yıla değişmek kaydıyla \%10 ila \%90 oranları arasında akbaşak zararının meydana gelebileceğini ifade etmektedir. Kılıç ve ark. (1973), aynı bölgede 1969 yılında yaptıkları çalışmada böcek yoğunluğu ile akbaşak zararı arasında genellikle doğru bir orantının göze çarptığını bildirmektedirler.

Lazarov et al. (1969), Bulgaristan'da 1965 yılında (E. integriceps)'nin neden olduğu ürün kayıplarını bulmak amacıyla doğada kafeslerde yaptıkları çalışmalar sonucunda; $\mathrm{m}^{2}$ 'de 1, 2, 3, 4 ve 5 adet KE bulunması durumunda akbaşak zararının sirasiyla $\% 3.56, \% 5.03, \% 6.97, \% 6.27$ ve $\% 9.00$ oranında olduğunu ortaya koymuşlardır.

Barbulescu (1973), Romanya'da 1965-1969 yılları arasında sünenin neden olduğu ürün kayıplarını ortaya koymak amacıyla; doğada kafeslerde (600-850 adet $\mathrm{m}^{-2}$ bitki) yaptığı denemeler sonucunda; $\mathrm{m}^{2}$ 'de 2, 5, 10 ve 20 adet kışlamış erginin sırasılyla ortalama \%5.2, \%12.0, \%16.0 ve \%23.0 oranlarında akbaşak zararı tespit etmiştir.

Tayakısı ve ark. (1973), Adana'da yaptıkları çalışmada KE yoğunluğunun düşük (0.2-0.6 adet $\mathrm{m}^{-2}$ ) olması nedeniyle akbaşak zararının önemli olmadığını bildirmektedirler.

Memişoğlu (1985), Orta Anadolu Bölgesi’nde E. maura kışlamış erginleri ile kafeslerde yaptığ 1 denemelerde; $\mathrm{m}^{2}$ 'de ortalama 16 adet kışlamış erginin y1llara göre değişmek kaydıyla ortalama \%0.95 ila \%2.49 arasında değişen oranlarda akbaşak zararına neden olabileceğini ortaya koymuştur.

Bahrami et al. (2003) Kermanşah-İran kuru tarımın yapıldığı buğday alanlarında ekonomik zarar eşiğini belirlemek amacıyla 1996-98 yıllarında 3.3 adet ms ${ }^{-2}$ kışlamış 
Orta Anadolu Bölgesi’nde buğdayda Avrupa Sünesi (Eurygaster maura L. Hemiptera: Scutelleridae)’nin neden olduğu ürün kayıpları ve ekonomik zarar eşiğinin belirlenmesi

erginin bulunan buğday tarlalarında çalışmalarını yürütmüş, her bir kışlamış erginin 61 adet orta sürgünü kurutarak ayrıca \%12.2 akbaşak oluşturarak üründe hektarda $126 \mathrm{~kg}$ azalmaya neden olduğunu bildirmektedir.

Canhilal et al. (2005), Güneydoğu Anadolu Bölgesi'nde m²'de 1, 2, 3, 5 ve 10 adet kışlamış ergin bulunan kafeslerde akbaşak zararının \%0.1-0.9 arasında değiştiğini bildirmektedirler.

\subsection{Geniş alan çalışmaları}

Geniş alan çalışmaları 2001-2002 üretim sezonunda Polatlı ve 2004-2005 üretim sezonunda da sulu tarımın yapıldığı Koçaş Tarım İşletmesi Müdürlüğü’ne ait buğday tarlalarında gerçekleştirilmiştir. 2002 yılında çalışmalara deneme tarlalarının etkileyen kışlaklarda (Polatlı Sivri Çaldağı, Ankara Ahırlıkuyu Çaldağı) süne inişlerinin başladığı 08.05.2002 tarihinde başlanılmış, inişlerin \%90'a ulaştı̆̆ 16.05.2002 tarihinden 2 gün sonra (18.05.2002) tarlalardaki kışlamış ergin yoğunluğunu belirlemek için sayımlar yapılmıştır. Sayımlar sonucunda her iki parselde de $\mathrm{m}^{2}$ de 0.9 adet kışlamış erginin bulunduğu belirlenmiştir. Aynı tarihte yapılan gözlemlerde buğdayın başaklanma-çiçeklenme döneminde olduğu saptanmıştır. 2001-2002 üretim sezonunda ekiliş toplam $312.4 \mathrm{~mm}$ yağış almış, $\mathrm{m}^{2}$ 'de 1 nolu parselde 426 adet, 2 nolu parselde de 463 adet başak oluşmuştur. Başak sayısının bu denli yüksek olması sonucunda akbaşak zararı oldukça düşük düzeylerde ortaya çıkmıştır (Çizelge 7). 2005 yılında çalışmalar Ekecik (Aksaray) kışlağının etki alanında bulunan Koçaş Tarım İşletmesi Müdürlüğü'ne ait sulanan Bezostaya çeşidi ekili buğday tarlalarında yürütülmüştür. Çalışmalar Ekecik kışlağında süne göçünün başladığı 11.05.2005 tarihinde başlanılmış, göçün \%90'ının tamamlandığ 18.05.2005 tarihinden 2 gün sonra yapılan sayımlarda $\mathrm{m}^{2}$ 'de 0.8 adet kışlamış erginin olduğu, buğdayında fenolojik dönem olarak çiçeklenme başlangıcında olduğu tespit edilmiştir. Çalışmaların yürütüldüğü parsellerin sulanması nedeniyle başak sayısının $\mathrm{m}^{2}$ 'de 623 adet gibi oldukça yüksek sayıda olması sebebiyle akbaşak zararının \%0.56 seviyesinde kaldığı belirlenmiş̧tir. Geniş alan çalışmalarında ortaya çıkan akbaşak zararının kafes çalışmalarına göre çok farklı olmasa da daha düşük olduğu belirlenmiştir. 
Özkan M., Babaroğlu N. E., Gökdoğan A., Kan M. ve Koçak E., Bitki Koruma Bülteni, 57 (2), 2017

Çizelge 6. Orta Anadolu Bölgesi’nde 2002 ve 2005 yıllarında geniş alan denemelerinin yürütüldüğü farklı kışlamış ergin yoğunluklarındaki başak, akbaşak sayıları ile akbaşak zararı.

\begin{tabular}{|c|c|c|c|c|c|c|}
\hline$\stackrel{\Xi}{\bar{\Xi}}$ & $\begin{array}{c}\text { Parsel } \\
\text { No }\end{array}$ & $\begin{array}{c}\text { Yer } \\
\text { Buğday } \\
\text { Çeşidi }\end{array}$ & $\begin{array}{l}\text { Kışlamış ergin } \\
\text { yoğunluğu } \\
\text { (adet } \mathbf{m}^{-2} \text { ) }\end{array}$ & $\begin{array}{c}\text { Başak sayısı } \\
\text { (adet } \mathbf{m}^{-2} \text { ) } \\
\text { Ort. } \pm \text { St.hata }\end{array}$ & $\begin{array}{c}\text { Akbaşak sayısı } \\
{\text { (adet } \mathbf{m}^{-2} \text { ) }}_{\text {Ort. } \pm \text { St.hata }}\end{array}$ & $\begin{array}{c}\text { Akbaşak zararı } \\
\text { (\%) } \\
\text { Ort. } \pm \text { St.hata }\end{array}$ \\
\hline \multirow{3}{*}{ 尺ิ } & 1 & \multirow{3}{*}{$\begin{array}{c}\text { Polatlı } \\
\text { T.I.M } \\
\text { Kizıltan }\end{array}$} & 0.9 & $426.67 \pm 9.84$ & $1.00 \pm 0.27$ & $0.23 \pm 0.06$ \\
\hline & 2 & & 0.9 & $463.33 \pm 33.29$ & $1.66 \pm 0.37$ & $0.36 \pm 0.08$ \\
\hline & Şahit & & 0.0 & $409.50 \pm 21.50$ & - & - \\
\hline \multirow[t]{2}{*}{ 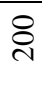 } & 1 & \multirow{2}{*}{$\begin{array}{c}\text { Koçaş } \\
\text { TíM } \\
\text { Bezostaya }\end{array}$} & 0.8 & $623.33 \pm 35.81$ & $3.50 \pm 0.50$ & $0.56 \pm 0.08$ \\
\hline & Şahit & & 0.0 & $679.00 \pm 37.59$ & - & - \\
\hline
\end{tabular}

$\mathrm{Bu}$ çalışmada elde edilen sonuçlar, ülkemizde ve yurtdışında yapılan diğer çalışmalarla da benzerlik göstermektedir.

Lazarov et al. (1969), Bulgaristan'da 1965 yılında süne (E. integriceps)'nin neden olduğu ürün kayıplarını bulmak amacıyla doğada buğday tarlalarında yaptıkları çalışmalarda $\mathrm{m}^{2}$ 'de $0.56,0.70$ ve 1.50 adet kışlamış erginin sırasıyla $\% 0.66, \% 0.81$ ve \%1.50 akbaşak zararına neden olduğunu saptamışlardır.

Kılıç ve ark. (1973), Güneydoğu Anadolu Bölgesi’nde 1969 yılında yaptıkları çalışmada $\mathrm{m}^{2}$ de 0.4 adet kışlamış erginin bulunması durumunda \%1.1; 1.0-1.5 adet bulunduğunda $\% 3.6 ; 1.6-2.0$ adet bulunduğunda $\% 4.2$ ve $2.1-2.3$ adet bulunduğunda ise \%6.6 akbaşak zararının ortaya çıktığını, böcek yoğunluğu ile zarar oranı arasında genellikle doğru bir orantının göz çarptığını bildirmektedirler.

Karkodi (2004), İran'da 1996-1997 yıllarında buğday tarlalarında yaptığı çalışmada, $\mathrm{m}^{2}$ 'de 1.9 adet kışlamış erginin olması durumunda $\mathrm{m}^{2}$ 'de 6.75 adet akbaşağın meydana gelebileceğini belirtmektedir.

Canhilal et al. (2005), Güneydoğu Anadolu Bölgesi'nde 2002-2003 y1llarında doğa koşullarında $\mathrm{m}^{2}$ 'de 0.2-2.4 adet kışlamış ergin bulunan 12 farklı lokasyonda yaptıkları çalışmalar sonucunda \%0.1-1.7 oranında akbaşak zararının olduğunu ve kışlamış ergin sayısı ile akbaşak zararı arasında herhangi bir ilişkinin olmadığını bildirmektedir.

Orta Anadolu Bölgesi'nde süne kışlamış erginlerinin buğdayda oluşturduğu akbaşak zararını ortaya koymak amacıyla 5 yıl süre ile yürütülen çalışmalar sonucunda; buğdayın fenolojik dönem olarak kardeşlenmeyi tamamlaması nedeniyle kurtboğazı zararının oluşmadığı, akbaşak zararının yıllara göre değişmekle birlikte yaklaşık $\% 0.9$ oranında oluştuğu söz konusu zararın $\mathrm{m}^{2}$ ' deki süne sayısının artmasına paralel olarak arttığı, $\mathrm{m}^{2}$ 'deki başak sayısının artmasına bağlı olarak da azaldığ belirlenmiştir. 
Orta Anadolu Bölgesi'nde buğdayda Avrupa Sünesi (Eurygaster maura L. Hemiptera: Scutelleridae)’nin neden olduğu ürün kayıpları ve ekonomik zarar eşiğinin belirlenmesi

\section{Tanedeki Emgi Zararı}

Sünenin nimf ve yeni nesil erginlerinin tanede beslenmeleri sonucu meydana getirdikleri zarar, kantite (nicelik) ve kalite (nitelik) yönünden araştırılmıştır.

\subsection{Kantite (nicelik) yönünden meydana gelen zarar}

Nimf ve yeni nesil erginlerin buğdayda meydana getirdiği ürün kaybını ortaya koymak amacıyla 1998, 1999, 2001 ve 2003 yıllarında doğa koşullarında yürütülen kafes denemelerinden elde edilen ortalama nimf, başak, başaktaki tane sayıları ile bin tane ağırlıkları ve emgi oranları Çizelge 8 ve Şekil 6'da verilmektedir.

Çizelge 7. Orta Anadolu Bölgesi’nde 1998, 1999, 2001 ve 2003 y1llarında tarla koşullarında yürütülen kafes denemelerinden elde edilen nimf, başak tane sayıları ile bin tane ağırlı̆̆ ve emgi oranları

\begin{tabular}{|c|c|c|c|c|c|c|}
\hline$\stackrel{\bar{\Xi}}{\Xi}$ & $\begin{array}{c}\text { K1şlamış ergin } \\
\left.\text { sayısı (adet } / \mathrm{m}^{2}\right) \\
\text { (Tekerrür } \\
\text { sayısı) }\end{array}$ & $\begin{array}{l}\text { Nimf say1s1 } \\
\text { (adet } \mathrm{m}^{-2} \text { ) } \\
\text { Ort. } \pm \text { St. hata } \\
\text { (min-max) }\end{array}$ & $\begin{array}{l}\text { Başak sayısı } \\
\text { (adet m-2 ) } \\
\text { Ort. } \pm \text { St. hata } \\
\text { (min-max) }\end{array}$ & $\begin{array}{c}\text { Tane say1s1 } \\
\text { (adet başak }^{-1} \text { ) } \\
\text { Ort. } \pm \text { St. hata } \\
\text { (min-max) }\end{array}$ & $\begin{array}{l}1000 \text { tane } \\
\text { ağırlığ }(\mathrm{g}) \\
\text { Ort. } \pm \text { St. hata } \\
\text { (min-max) }\end{array}$ & $\begin{array}{c}\text { Emgi oran1 } \\
\text { (\%) } \\
\text { Ort. } \pm \text { St. hata } \\
\text { (min-max) }\end{array}$ \\
\hline \multirow{6}{*}{$\stackrel{\infty}{\mathscr{\sigma}}$} & $0.50(4)$ & $\begin{array}{c}4.31 \pm 1.91 \\
(1.75-10.00) \\
\end{array}$ & $\begin{array}{c}387.94 \pm 23.97 \\
(346.25-448.00 \\
\end{array}$ & $\begin{array}{c}24.35 \pm 0.71 \\
(22.53-25.84) \\
\end{array}$ & $\begin{array}{c}25.92 \pm 0.29 \\
(25.13-26.51)\end{array}$ & $\begin{array}{c}3.00 \pm 0.88 \\
(1.80-5.60) \\
\end{array}$ \\
\hline & $0.75(4)$ & $\begin{array}{c}3.56 \pm 1.08 \\
(1.50-6.50)\end{array}$ & $\begin{array}{c}380.50 \pm 15.09 \\
(337.50-404.50 \\
\end{array}$ & $\begin{array}{c}24.27 \pm 1.11 \\
(22.20-27.35)\end{array}$ & $\begin{array}{c}24.85 \pm 1.05 \\
(23.15-27.82)\end{array}$ & $\begin{array}{c}2.35 \pm 0.87 \\
(0.80-4.40)\end{array}$ \\
\hline & $1.00(3)$ & $\begin{array}{c}10.06 \pm 4.04 \\
(2.50-21.50)\end{array}$ & $\begin{array}{c}405.19 \pm 24.14 \\
(346.25-457.50)\end{array}$ & $\begin{array}{c}23.93 \pm 1.39 \\
(20.92-26.43)\end{array}$ & $\begin{array}{c}25.22 \pm 0.90 \\
(23.86-27.87)\end{array}$ & $\begin{array}{c}3.70 \pm 1.55 \\
(1.20-8.20)\end{array}$ \\
\hline & $1.25(4)$ & $\begin{array}{c}6.92 \pm 1.64 \\
(3.75-9.25) \\
\end{array}$ & $\begin{array}{c}442.50 \pm 89.54 \\
(308.75-612.50\end{array}$ & $\begin{array}{c}21.57 \pm 0.88 \\
(20.68-23.33) \\
\end{array}$ & $\begin{array}{c}25.89 \pm 0.55 \\
(24.82-26.68)\end{array}$ & $\begin{array}{c}3.87 \pm 0.67 \\
(3.20-5.20)\end{array}$ \\
\hline & Şahit (4) & $\begin{array}{c}0.00 \pm 0.00 \\
(0.00-0.00)\end{array}$ & $\begin{array}{c}402.44 \pm 22.19 \\
(354.75-452.50 \\
\end{array}$ & $\begin{array}{c}21.17 \pm 1.15 \\
(19.41-24.37)\end{array}$ & $\begin{array}{c}24.60 \pm 1.17 \\
(21.79-27.18)\end{array}$ & $\begin{array}{c}0.00 \pm 0.00 \\
(0.00-0.00)\end{array}$ \\
\hline & Ortalama (19) & $\begin{array}{c}4.87 \pm 1.20 \\
(0.00-21.50)\end{array}$ & $\begin{array}{c}401.67 \pm 15.12 \\
(308.75-612.50)\end{array}$ & $\begin{array}{c}23.13 \pm 0.54 \\
(19.41-27.35)\end{array}$ & $\begin{array}{c}25.27 \pm 0.37 \\
(21.79-27.87)\end{array}$ & $\begin{array}{l}2.52 \pm 0.50 \\
(0.00-8.20)\end{array}$ \\
\hline \multirow{7}{*}{$\begin{array}{l}\mathscr{a} \\
\stackrel{\sigma}{ }\end{array}$} & $0.50(8)$ & $\begin{array}{c}5.53 \pm 1.27 \\
(2.00-13.50)\end{array}$ & $\begin{array}{c}496.31 \pm 26.74 \\
(309.00-576.75 \\
\end{array}$ & $\begin{array}{c}27.70 \pm 0.81 \\
(22.75-30.98)\end{array}$ & $\begin{array}{c}44.24 \pm 1.26 \\
(40.85-47.54)\end{array}$ & $\begin{array}{c}2.42 \pm 0.88 \\
(0.20-8.30)\end{array}$ \\
\hline & $0.75(7)$ & $\begin{array}{c}3.79 \pm 0.56 \\
(2.00-5.75) \\
\end{array}$ & $\begin{array}{c}554.04 \pm 30.85 \\
(444.5-661.75) \\
\end{array}$ & $\begin{array}{c}27.49 \pm 0.64 \\
(25.61-30.06)\end{array}$ & $\begin{array}{c}41.22 \pm 2.47 \\
(33.63-51.62)\end{array}$ & $\begin{array}{c}0.85 \pm 0.21 \\
(0.40-1.80)\end{array}$ \\
\hline & $1.00(7)$ & $\begin{array}{c}6.64 \pm 1.48 \\
(1.75-11.75)\end{array}$ & $\begin{array}{c}540.82 \pm 26.32 \\
(416.75-612.50)\end{array}$ & $\begin{array}{c}27.68 \pm 0.54 \\
(26.05-30.34)\end{array}$ & $\begin{array}{c}40.32 \pm 1.80 \\
(33.79-46.85)\end{array}$ & $\begin{array}{c}2.23 \pm 0.58 \\
(0.10-4.10)\end{array}$ \\
\hline & 1.25 (8) & $\begin{array}{c}5.38 \pm 0.89 \\
(1.75-8.75)\end{array}$ & $\begin{array}{c}552.41 \pm 23.29 \\
(462.75-637.50\end{array}$ & $\begin{array}{c}27.29 \pm 0.42 \\
(25.47-28.90)\end{array}$ & $\begin{array}{c}42.13 \pm 1.90 \\
(32.86-48.47)\end{array}$ & $\begin{array}{c}2.43 \pm 0.49 \\
(0.90-4.80)\end{array}$ \\
\hline & 1.50 (8) & $\begin{array}{c}15.38 \pm 3.09 \\
(4.00-29.25)\end{array}$ & $\begin{array}{c}504.53 \pm 25.87 \\
(402.00-640.00)\end{array}$ & $\begin{array}{c}29.31 \pm 0.80 \\
(25.98-32.09)\end{array}$ & $\begin{array}{c}40.06 \pm 2.18 \\
(28.33-46.82)\end{array}$ & $\begin{array}{c}4.74 \pm 0.94 \\
(0.80-7.80)\end{array}$ \\
\hline & Şahit (8) & $\begin{array}{c}0.00 \pm 0.00 \\
(0.00-0.00)\end{array}$ & $\begin{array}{c}531.94 \pm 19.26 \\
(453.75-588.75\end{array}$ & $\begin{array}{c}27.50 \pm 0.79 \\
(23.00-30.48)\end{array}$ & $\begin{array}{c}42.66 \pm 0.88 \\
(39.18-46.09)\end{array}$ & $\begin{array}{c}0.00 \pm 0.00 \\
(0.00-0.00)\end{array}$ \\
\hline & Ortalama (46) & $\begin{array}{c}6.20 \pm 0.94 \\
(0.00-29.25)\end{array}$ & $\begin{array}{c}527.99 \pm 10.34 \\
(309.00-661.75)\end{array}$ & $\begin{array}{c}27.84 \pm 0.29 \\
(22.75-32.09)\end{array}$ & $\begin{array}{c}41.88 \pm 0.71 \\
(28.33-51.62)\end{array}$ & $\begin{array}{c}2.17 \pm 0.34 \\
(0.00-8.30)\end{array}$ \\
\hline
\end{tabular}


Çizelge 8. (Devamı)

\begin{tabular}{|c|c|c|c|c|c|c|}
\hline$\stackrel{\bar{z}}{\equiv}$ & $\begin{array}{l}\text { Kışlamış ergin } \\
\text { sayı1s }\left(\text { adet } / m^{2} \text { ) }\right. \\
\text { (Tekerrür sayısı) }\end{array}$ & $\begin{array}{l}\text { Nimf sayıs1 } \\
{\text { (adet } \mathrm{m}^{-2} \text { ) }} \text { Ort. } \pm \text { St. hata } \\
\text { (min-max) }\end{array}$ & $\begin{array}{l}\text { Başak sayısı } \\
\text { (adet m² ) } \\
\text { Ort. } \pm \text { St. hata } \\
\text { (min-max) }\end{array}$ & $\begin{array}{c}\text { Tane sayıs } \\
\left(\text { adet başak }^{-1}\right) \\
\text { Ort. } \pm \text { St. hata } \\
\text { (min-max) }\end{array}$ & $\begin{array}{l}1000 \text { tane } \\
\text { ağırlığı (g) } \\
\text { Ort. } \pm \text { St. hata } \\
\text { (min-max) }\end{array}$ & $\begin{array}{c}\text { Emgi oran1 } \\
\text { (\%) } \\
\text { Ort. } \pm \text { St. hata } \\
\text { (min-max) }\end{array}$ \\
\hline \multirow{4}{*}{ চ্் } & $1.00(7)$ & $\begin{array}{c}7,79 \pm 1,71 \\
(1,75-12,75)\end{array}$ & $\begin{array}{c}254,46 \pm 15,01 \\
(206,00-309,00)\end{array}$ & $\begin{array}{c}23,20 \pm 0,63 \\
(20,69-25,79)\end{array}$ & $\begin{array}{c}37,27 \pm 0,13 \\
(36,80-37,65) \\
\end{array}$ & $\begin{array}{c}8,46 \pm 0,95 \\
(5,20-11,90) \\
\end{array}$ \\
\hline & 1.50 (8) & $\begin{array}{c}9,41 \pm 2,44 \\
(4,00-24,00)\end{array}$ & $\begin{array}{c}295,91 \pm 24,47 \\
(191,00-358,00) \\
\end{array}$ & \begin{tabular}{|c|}
$24,40 \pm 0,51$ \\
$(22,77-26,69)$ \\
\end{tabular} & \begin{tabular}{|c|}
$37,20 \pm 0,57$ \\
$(34,52-39,04)$ \\
\end{tabular} & $\begin{array}{c}12,01 \pm 2,08 \\
(6,80-23,60) \\
\end{array}$ \\
\hline & Şahit (4) & $\begin{array}{c}0,00 \pm 0,00 \\
(0,00-0,00)\end{array}$ & $\begin{array}{c}269,00 \pm 9,64 \\
(244,00-310,75)\end{array}$ & $\begin{array}{c}23,79 \pm 0,38 \\
(22,80-24,51)\end{array}$ & $\begin{array}{c}39,26 \pm 0,86 \\
(37,59-41,64) \\
\end{array}$ & $\begin{array}{c}0,00 \pm 0,00 \\
(0,00-0,00)\end{array}$ \\
\hline & Ortalama (27) & $\begin{array}{c}7,58 \pm 1,41 \\
(0,00-30,50)\end{array}$ & \begin{tabular}{|c|}
$272,14 \pm 9,57$ \\
$(191,00-358,00)$ \\
\end{tabular} & $\begin{array}{c}23,66 \pm 0,53 \\
(18,49-31,28)\end{array}$ & \begin{tabular}{|c|}
$36,91 \pm 0,54$ \\
$(25,03-41,64)$
\end{tabular} & $\begin{array}{c}8,46 \pm 1,12 \\
(0,00-23,60)\end{array}$ \\
\hline \multirow{5}{*}{ ஜి } & $0.50(5)$ & $\begin{array}{c}6,45 \pm 2,72 \\
(2,25-16,25)\end{array}$ & \begin{tabular}{|c|}
$326,00 \pm 13,88$ \\
$(283,00-362,50)$ \\
\end{tabular} & \begin{tabular}{|c|}
$30,13 \pm 0,69$ \\
$(28,39-31,88)$ \\
\end{tabular} & \begin{tabular}{|c|}
$35,64 \pm 1,48$ \\
$(29,99-38,16)$ \\
\end{tabular} & $\begin{array}{c}4,46 \pm 1,45 \\
(1,10-9,70)\end{array}$ \\
\hline & $1.00(6)$ & $\begin{array}{c}17,50 \pm 4,01 \\
(7,00-31,25)\end{array}$ & \begin{tabular}{|c|}
$335,33 \pm 13,83$ \\
$(288,00-381,50)$ \\
\end{tabular} & $\begin{array}{c}30,07 \pm 1,19 \\
(25,59-33,30) \\
\end{array}$ & $\begin{array}{c}32,08 \pm 0,80 \\
(29,95-35,70) \\
\end{array}$ & $\begin{array}{c}7,80 \pm 1,45 \\
(4,00-13,80) \\
\end{array}$ \\
\hline & $1.50(6)$ & $\begin{array}{c}22,92 \pm 7,65 \\
(3,50-46,25) \\
\end{array}$ & \begin{tabular}{|c|}
$319,58 \pm 10,67$ \\
$(275,00-352,00)$ \\
\end{tabular} & \begin{tabular}{|c|}
$31,26 \pm 0,63$ \\
$(28,69-33,16)$ \\
\end{tabular} & \begin{tabular}{|c|}
$31,38 \pm 1,30$ \\
$(26,00-34,38)$ \\
\end{tabular} & $\begin{array}{c}9,52 \pm 1,67 \\
(3,20-14,00) \\
\end{array}$ \\
\hline & Şahit (6) & $\begin{array}{c}0,00 \pm 0,00 \\
(0,00-0,00)\end{array}$ & $\begin{array}{c}348,13 \pm 14,06 \\
(308,75-405,25)\end{array}$ & $\begin{array}{c}29,77 \pm 0,51 \\
(28,79-32,22)\end{array}$ & $\begin{array}{c}33,04 \pm 1,49 \\
(29,24-37,46)\end{array}$ & $\begin{array}{c}0,00 \pm 0,00 \\
(0,00-0,00)\end{array}$ \\
\hline & Ortalama (23) & $\begin{array}{c}11,95 \pm 2,92 \\
(0,00-46,25)\end{array}$ & \begin{tabular}{|c|}
$332,53 \pm 6,54$ \\
$(275,0-405,25)$ \\
\end{tabular} & \begin{tabular}{|c|}
$30,31 \pm 0,40$ \\
$(25,59-33,30)$ \\
\end{tabular} & \begin{tabular}{|c|}
$32,92 \pm 0,68$ \\
$(26,00-38,16)$ \\
\end{tabular} & $\begin{array}{c}5,49 \pm 1,00 \\
(0,00-14,00) \\
\end{array}$ \\
\hline \multicolumn{2}{|r|}{$\begin{array}{c}\text { GENEL } \\
\text { ORTALAMA } \\
(115)\end{array}$} & $\begin{array}{c}7,45 \pm 0,81 \\
(0,00-46,25)\end{array}$ & $\begin{array}{c}407,96 \pm 11,31 \\
(191,0-661,75)\end{array}$ & $\begin{array}{c}26,58 \pm 0,33 \\
(18,49-33,30)\end{array}$ & $\begin{array}{c}36,18 \pm 0,65 \\
(21,79-51,62)\end{array}$ & $\begin{array}{c}4,37 \pm 0,43 \\
(0,00-23,60)\end{array}$ \\
\hline
\end{tabular}

Çizelge 8 ve Şekil 6 incelendiğinde; toplam 115 adet kafeste buğdayın verimini belirleyen temel öğeleri olan $\mathrm{m}^{2}$ 'deki başak ve başaktaki tane sayıları ile 1000 tane ağırlığ 1 yıllara göre değişmekle birlikte sırasıyla ortalama 407.96 adet m²; 26.58 adet başak $^{-1}$ ve 36.18 gram olduğu görülecektir. Aynı süre içerisinde süne nimf ve yeni nesil ergin yoğunluğu 7.45 adet $\mathrm{m}^{-2}$, ortalama süne emgi oranı da $\% 4.37$ olarak belirlenmiştir.

Doğal bulaşmanın olduğu Orta Anadolu Bölgesi illeri; Ankara, Aksaray, Konya ve Kırşehir buğday ekim alanlarında 4 yıl süresince (2002-2005) yürütülen geniş alan çalışmalarından elde edilen veriler incelendiğinde (Çizelge 9), kışlamış ergin yoğunluğunun 0.4-1.0 adet $\mathrm{m}^{-2}$, nimf yoğunluğunun 0.00-38.67 adet $\mathrm{m}^{-2}$, başak yoğunluğunun 306.00-679.00 adet $\mathrm{m}^{-2}$, başaktaki tane sayısının 21.58-35.38 adet başak $^{-1}$ bin tane ağırlığının 33.45-41.40 g ve emgi oranında \%0.20-9.60 oranında olduğu görülecektir. 
Orta Anadolu Bölgesi'nde buğdayda Avrupa Sünesi (Eurygaster maura L. Hemiptera: Scutelleridae)'nin neden olduğu ürün kayıpları ve ekonomik zarar eşiğinin belirlenmesi

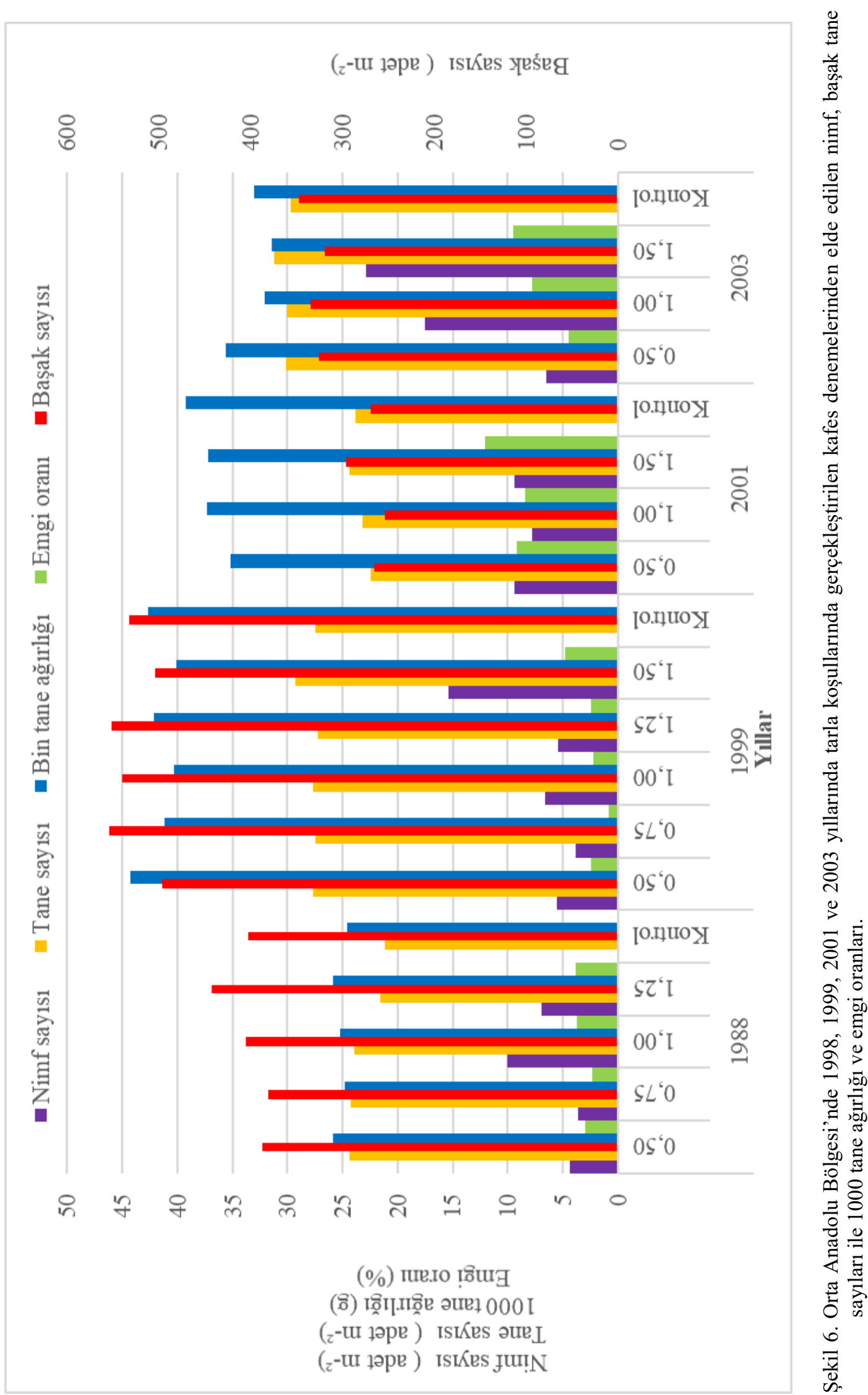


Çizelge 8. Orta Anadolu Bölgesi'nde 1998, 1999, 2001 ve 2003 y1llarında tarla koşullarında gerçekleştirilen geniş alan denemelerinden elde edilen nimf, başak tane sayıları ile 1000 tane ağırlığı ve emgi oranları.

\begin{tabular}{|c|c|c|c|c|c|c|c|c|}
\hline$\stackrel{\bar{\Xi}}{\Xi}$ & $\begin{array}{c}\text { Yer } \\
\text { (Buğday } \\
\text { çeşidi) }\end{array}$ & $\begin{array}{c}\text { Parsel } \\
\text { No }\end{array}$ & $\begin{array}{c}\text { K. E. } \\
\text { sayıs1 } \\
\left({\text { adet } \mathrm{m}^{-2} \text { ) }}^{2}\right.\end{array}$ & 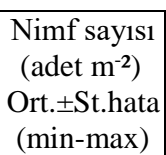 & $\begin{array}{l}\text { Başak sayıs1 } \\
\text { (adet m }^{-2} \text { ) } \\
\text { Ort. } \pm \text { St.hata } \\
\text { (min-max) }\end{array}$ & $\begin{array}{c}\text { Tane say1s1 } \\
\text { (adet/başak) } \\
\text { Ort. } \pm \text { St.hata } \\
\text { (min-max) }\end{array}$ & $\begin{array}{c}1000 \text { tane } \\
\text { ăgırlığ } 1(\mathrm{~g}) \\
\text { Ort. } \pm \text { St.hata } \\
\text { (min-max) }\end{array}$ & $\begin{array}{l}\text { Emgi } \\
\text { oran1 } \\
(\%) \\
\text { Ort. }\end{array}$ \\
\hline \multirow{3}{*}{ ָㅗㅇ } & \multirow{3}{*}{$\begin{array}{l}\text { Polatlı TíM } \\
\text { (Kiz1ltan) }\end{array}$} & 1 & 0.9 & $\begin{array}{c}22.33 \pm 4.37 \\
(17-31)\end{array}$ & $\begin{array}{c}426.66 \pm 9.84 \\
(409-443)\end{array}$ & $\begin{array}{c}25.98 \pm 0.64 \\
(9-43)\end{array}$ & \begin{tabular}{|c|}
$37.53 \pm 1.46$ \\
$(34.19-39.22)$
\end{tabular} & 5.80 \\
\hline & & 2 & 0.9 & $\begin{array}{c}38.67 \pm 4.63 \\
(31-47)\end{array}$ & $\begin{array}{c}463.33 \pm 40.45 \\
(385-520)\end{array}$ & $\begin{array}{c}27.45 \pm 0.60 \\
(10-43)\end{array}$ & \begin{tabular}{|c|}
$34.59 \pm 1.41$ \\
$(30.18-35.08)$
\end{tabular} & 9.60 \\
\hline & & $\begin{array}{c}3 \\
\text { (Şahit) } \\
\end{array}$ & 0.9 & $\begin{array}{c}3.67 \pm 1.24 \\
(1-3)\end{array}$ & $\begin{array}{c}409.33 \pm 27.42 \\
(362-457)\end{array}$ & $\begin{array}{c}26.80 \pm 3.94 \\
(10-34)\end{array}$ & \begin{tabular}{|c|}
$37.37 \pm 1.77$ \\
$(34.44-43.56)$
\end{tabular} & 0.80 \\
\hline \multirow{2}{*}{$\stackrel{m}{8}$} & \multirow{2}{*}{$\begin{array}{c}\text { Bala TİM } \\
\text { (Bezostaya) }\end{array}$} & 1 & 0.9 & $\begin{array}{c}23.89 \pm 1.76 \\
(12-44)\end{array}$ & $\begin{array}{c}401.33 \pm 9.53 \\
(385-418)\end{array}$ & $\begin{array}{c}35.38 \pm 0.2 \\
(16-62)\end{array}$ & \begin{tabular}{|c|}
$39.43 \pm 2.19$ \\
$(35.70-43.30)$
\end{tabular} & 6.90 \\
\hline & & \begin{tabular}{|c|}
2 \\
(Şahit) \\
\end{tabular} & 0.9 & $\begin{array}{c}3.25 \pm 0.49 \\
(1-7)\end{array}$ & $\begin{array}{c}414.25 \pm 33.32 \\
(373-513)\end{array}$ & $\begin{array}{c}33.06 \pm 0.65 \\
(16-48)\end{array}$ & $\begin{array}{c}38.57 \pm 1.16 \\
(36.27-39.96)\end{array}$ & 1.00 \\
\hline \multirow{12}{*}{ ঠ্ণ } & \multirow{2}{*}{$\begin{array}{l}\text { Malya TIM } \\
\text { (Bezostaya) }\end{array}$} & 1 & 0.5 & 4.00 & $\begin{array}{c}514.33 \pm 4.33 \\
(507-522)\end{array}$ & $\begin{array}{c}25.29 \pm 0.31 \\
(10-40)\end{array}$ & $\begin{array}{c}37.33 \pm 2.42 \\
(33.10-41.50)\end{array}$ & 1.20 \\
\hline & & 2 & 0.5 & 5.00 & $\begin{array}{c}519.00 \pm 19.05 \\
(486-552)\end{array}$ & $\begin{array}{c}33.86 \pm 0.41 \\
(15-56)\end{array}$ & $\begin{array}{c}38.36 \pm 1.08 \\
(36.36-40.08)\end{array}$ & 0.80 \\
\hline & $\begin{array}{l}\text { Polatlı TİM } \\
\text { (Bezostaya) }\end{array}$ & 3 & 0.6 & 5.00 & $\begin{array}{c}491.33 \pm 18.19 \\
(460-523) \\
\end{array}$ & $\begin{array}{c}26.34 \pm 0.29 \\
(10-42)\end{array}$ & $\begin{array}{c}39.18 \pm 1.35 \\
(36.74-41.44) \\
\end{array}$ & 1.30 \\
\hline & \multirow{4}{*}{$\begin{array}{c}\text { Kırşehir } \\
\text { (Bezostaya) }\end{array}$} & 4 & 0.4 & 7.00 & $\begin{array}{c}571.33 \pm 11.84 \\
(551-592)\end{array}$ & $\begin{array}{c}23.96 \pm 0.50 \\
(16-32)\end{array}$ & & 1.90 \\
\hline & & 5 & 0.4 & 7.00 & $\begin{array}{c}649.00 \pm 17.89 \\
(618-680)\end{array}$ & $\begin{array}{c}23.40 \pm 0.58 \\
(16-33)\end{array}$ & & 2.00 \\
\hline & & 6 & 0.4 & 5.00 & $\begin{array}{c}541.00 \pm 4.62 \\
(533-549)\end{array}$ & $\begin{array}{c}23.19 \pm 0.45 \\
(15-29)\end{array}$ & & 1.00 \\
\hline & & 7 & 0.5 & 7.00 & $\begin{array}{c}569.00 \pm 1.15 \\
(567-571) \\
\end{array}$ & $\begin{array}{c}23.04 \pm 0.66 \\
(9-32)\end{array}$ & & 1.60 \\
\hline & $\begin{array}{l}\text { Koçaş TİM } \\
\text { (Bezostaya) }\end{array}$ & 8 & 0.8 & $\begin{array}{c}14.33 \pm 1.76 \\
(11-17)\end{array}$ & $\begin{array}{c}532.00 \pm 25.51 \\
(481-559)\end{array}$ & $\begin{array}{c}26.37 \pm 0.34 \\
(8-41)\end{array}$ & $\begin{array}{c}40.05 \pm 2.19 \\
(36.86-44.24)\end{array}$ & 3.00 \\
\hline & \multirow{3}{*}{$\begin{array}{l}\text { Kurşehir } \\
\text { (Pehlivan) }\end{array}$} & 9 & 0.5 & 2.00 & $\begin{array}{c}424.33 \pm 3.18 \\
(419-430) \\
\end{array}$ & $\begin{array}{c}29.77 \pm 0.80 \\
(7-30)\end{array}$ & & 1.20 \\
\hline & & 10 & 0.5 & 5.00 & $\begin{array}{c}514.33 \pm 1.45 \\
(512-517)\end{array}$ & $\begin{array}{c}28.27 \pm 0.61 \\
(8-25)\end{array}$ & & 1.30 \\
\hline & & 11 & 0.6 & 12.00 & $\begin{array}{c}455.33 \pm 1.84 \\
(435-476)\end{array}$ & $\begin{array}{c}26.52 \pm 0.76 \\
(7-26)\end{array}$ & & 5.70 \\
\hline & $\begin{array}{l}\text { Gözlü TİM } \\
\text { (Gerek 79) }\end{array}$ & 12 & 1.0 & $\begin{array}{c}21.25 \pm 0.75 \\
(20-23)\end{array}$ & $\begin{array}{c}306.00 \pm 1.15 \\
(304-308)\end{array}$ & $\begin{array}{c}22.90 \pm 0.41 \\
(2-51)\end{array}$ & $\begin{array}{c}33.45 \pm 1.10 \\
(31.45-35.26)\end{array}$ & 6.80 \\
\hline \multirow{2}{*}{ 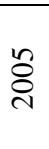 } & \multirow{2}{*}{$\begin{array}{l}\text { Koçaş TíM } \\
\text { (Bezostaya) }\end{array}$} & 1 & 0.8 & $\begin{array}{c}6.50 \pm 1.19 \\
(4-9)\end{array}$ & $\begin{array}{c}623.33 \pm 50.07 \\
(565-723)\end{array}$ & $\begin{array}{c}24.37 \pm 0.31 \\
(3-49)\end{array}$ & $\begin{array}{c}41.40 \pm 2.10 \\
(37.20-43.56)\end{array}$ & 1.34 \\
\hline & & \begin{tabular}{|c|}
2 \\
Şahit)
\end{tabular} & 0.8 & $\begin{array}{c}0.00 \pm 0.00 \\
(0.0-0.0)\end{array}$ & $\begin{array}{c}679.00 \pm 48.50 \\
(619-775)\end{array}$ & $\begin{array}{c}21.58 \pm 0.33 \\
(2-51)\end{array}$ & $\begin{array}{c}39.16 \pm 0.18 \\
(38.8 / 4-39.48\end{array}$ & 0.20 \\
\hline
\end{tabular}


Orta Anadolu Bölgesi'nde buğdayda Avrupa Sünesi (Eurygaster maura L. Hemiptera: Scutelleridae)'nin neden olduğu ürün kayıpları ve ekonomik zarar eşiğinin belirlenmesi

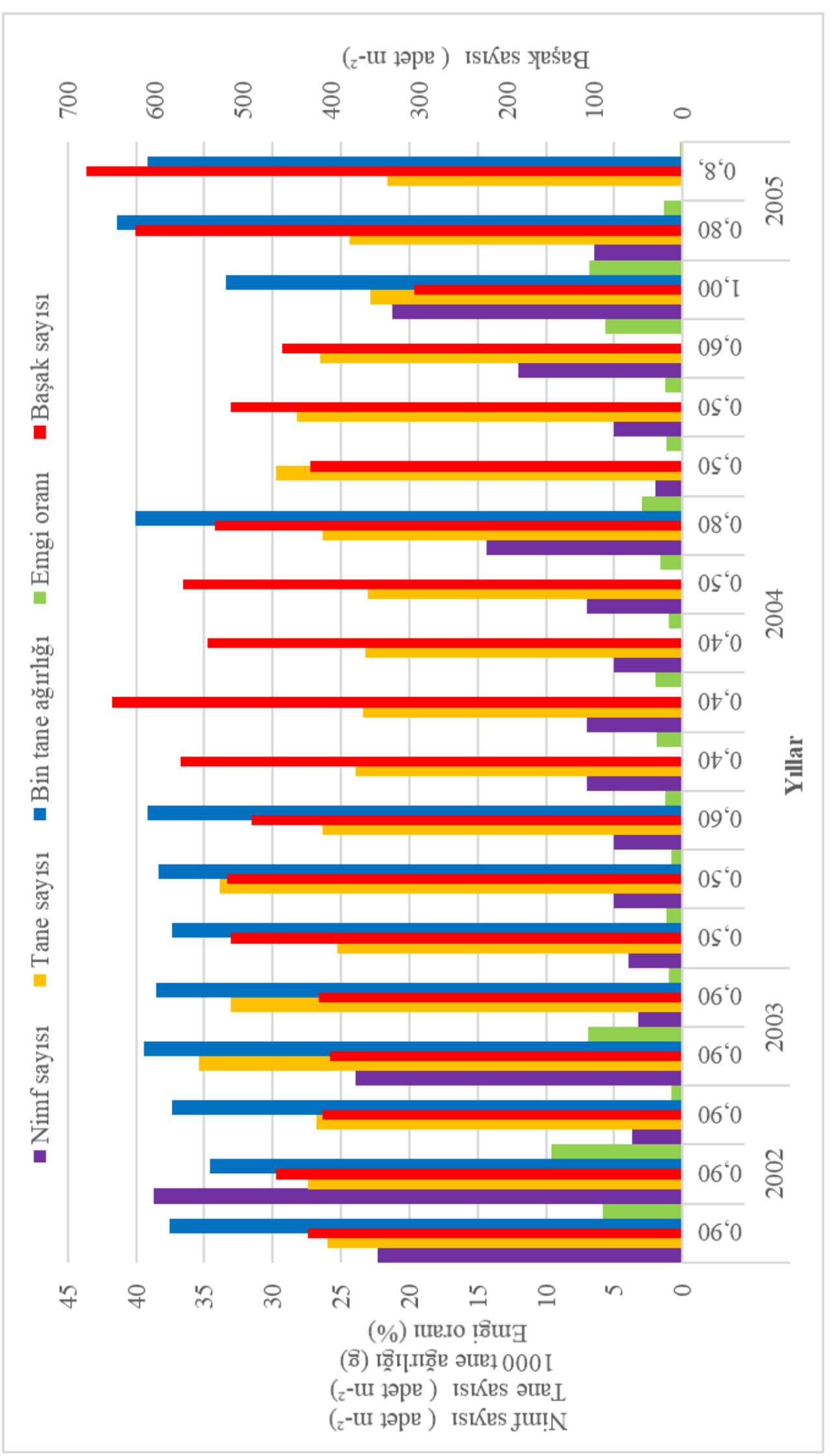


Tarla koşullarında yürütülen geniş alan ve kafes denemeleri sonuçları birlikte değerlendirildiğinde; buğdayın verimini belirleyen temel öğeleri olan $\mathrm{m}^{2}$ deki başak, başaktaki tane sayılarında ve tane ağırlı̆̆ında meydana gelen değişimlere süne yoğunluğunun etkisini belirlemek amacıyla yapılan korelasyon analiz sonuçları Çizelge 10 ve Şekil 6-7'de verilmektedir. Zararlı yoğunluğunun $\mathrm{m}^{2}$ deki başak sayısındaki değişime etkisinin $\left(\mathrm{r}^{2}\right)$ oldukça düşük ve önemsiz olduğu, söz konusu durumun başaktaki tane sayısı ve 1000 tane ağırlığı için de geçerli olduğu aynı Çizelge ve Şekiller incelendiğinde görülecektir. Aynı Çizelgede 2002-2005 yıllarında yürütülen geniş alan çalışma sonuçları incelendiğinde de benzer sonuçların elde edildiği görülecektir. Geniş alan çalışmalarında görülen nimf yoğunluğu ile $\mathrm{m}^{2}$ deki başak sayısı arasındaki negatif yöndeki zayıf ilişkinin (\%21.20) nimf yoğunluğu ile $\mathrm{m}^{2}$ deki başak sayısı arasındaki ilişkiden kaynaklanmadığı, bu ilişki iklim koşullarına bağlı olarak; kurak yıllarda nimf yoğunluğunun yüksek, nimf sayısından bağımsız olarak $\mathrm{m}^{2}$ 'deki başak sayısının düşük olması nedeniyle ortaya çıtığı belirlenmiştir. Bunun tersi olarak yağışlı yıllarda $\mathrm{m}^{2}$ deki başak sayısının artmakta, nimf yoğunluğunun azalmakta olduğu tespit edilmiştir.

Çizelge 9. Nimf sayısı ile 1000 tane ağırlığı, başak ve tane sayıları arasındaki ilişki.

\begin{tabular}{|c|c|c|c|c|c|c|c|c|}
\hline & & İstatistiksel & & Kaf & s denen & eleri & & $\begin{array}{l}\text { Geniş alan } \\
\text { denemeleri }\end{array}$ \\
\hline & Karakterler & veriler & & & lar & & & \\
\hline & & & 1998 & 1999 & 2001 & 2003 & Tǜ & n yillar \\
\hline & & $\mathrm{r}$ & 0.275 & -0.125 & 0.254 & -0.192 & -0.126 & $-0.460^{*}$ \\
\hline & Başak sayısı & $\mathrm{r}^{2}$ & 0,076 & 0,016 & 0,065 & 0,037 & 0,016 & 0.212 \\
\hline$\overparen{\top}$ & (adet $\mathrm{m}^{-2}$ ) & Önem seviyesi & 0.254 & 0.407 & 0.200 & 0.380 & 0.181 & 0.041 \\
\hline$\Xi$ & & Tekerrür sayı1s1 & 19 & 46 & 27 & 23 & 115 & 20 \\
\hline 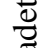 & & $\mathrm{r}$ & 0.371 & -0.081 & -0.320 & 0.151 & -0.111 & -0.524 \\
\hline$\underbrace{\pi}_{-\pi}$ & 1000 tane & $\mathrm{r}^{2}$ & 0.138 & 0.007 & 0.102 & 0,023 & 0.012 & 0.275 \\
\hline$\sum_{2}^{\infty}$ & ağırlı̆̆ı (g) & Önem seviyesi & 0.118 & 0.591 & 0.103 & 0.492 & 0.238 & 0.080 \\
\hline 趈 & & Tekerrür say1s1 & 19 & 46 & 27 & 23 & 115 & 12 \\
\hline$\Xi$ & & $\mathrm{r}$ & -0.015 & 0.252 & -0.159 & -0.272 & 0.172 & 0.182 \\
\hline Z & Tane say1s1 & $\mathrm{r}^{2}$ & 0.000 & 0.064 & 0.025 & 0.074 & 0.030 & 0.033 \\
\hline & $\left(\right.$ adet başak $\left.^{-1}\right)$ & Önem seviyesi & 0.953 & 0.091 & 0.428 & 0.210 & 0.066 & 0.442 \\
\hline & & Tekerrür say1s1 & 19 & 46 & 27 & 23 & 115 & 20 \\
\hline
\end{tabular}


Orta Anadolu Bölgesi’nde buğdayda Avrupa Sünesi (Eurygaster maura L. Hemiptera: Scutelleridae)’nin neden olduğu ürün kayıpları ve ekonomik zarar eşiğinin belirlenmesi

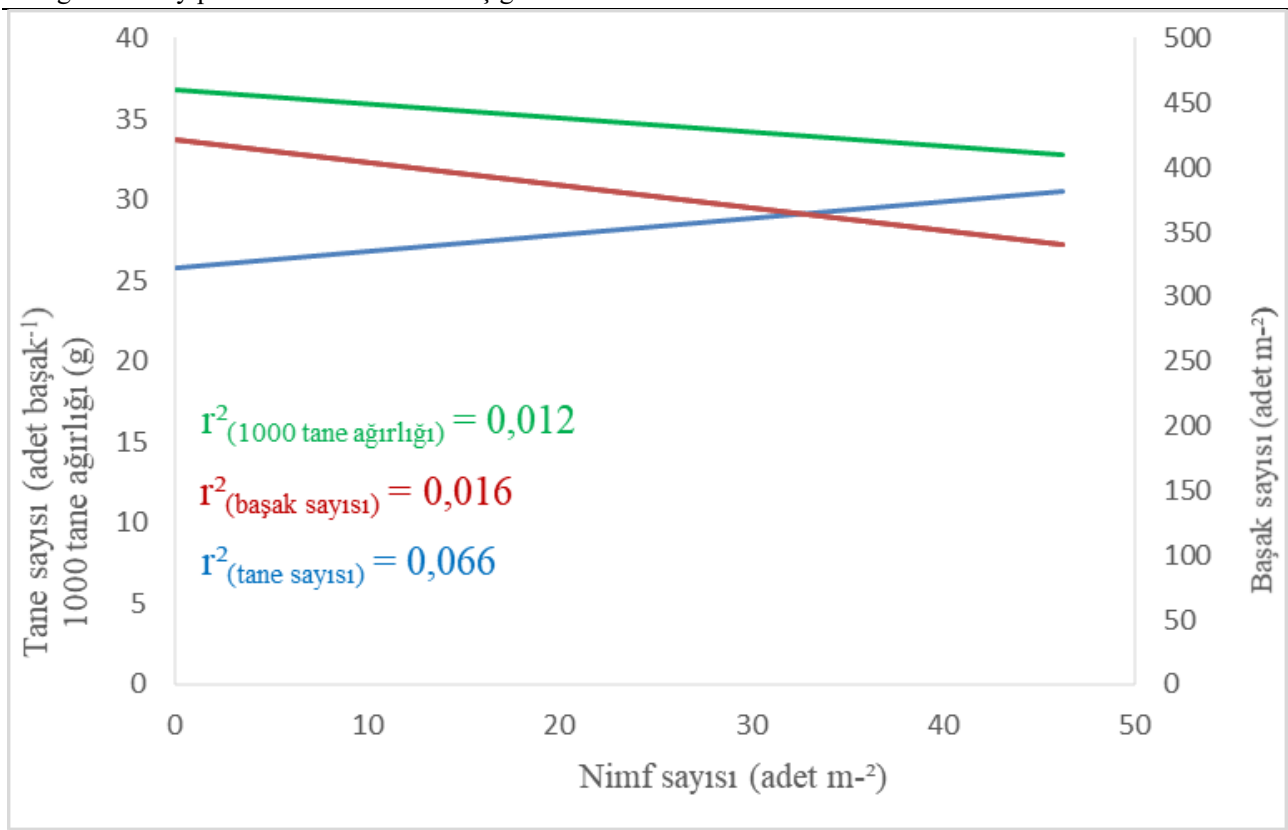

Şekil 6. Kafes denemelerinden elde edilen farklı nimf yoğunlukları ile tane, başak sayıları ve 1000 tane ağırlığına ait regresyon doğrusu.

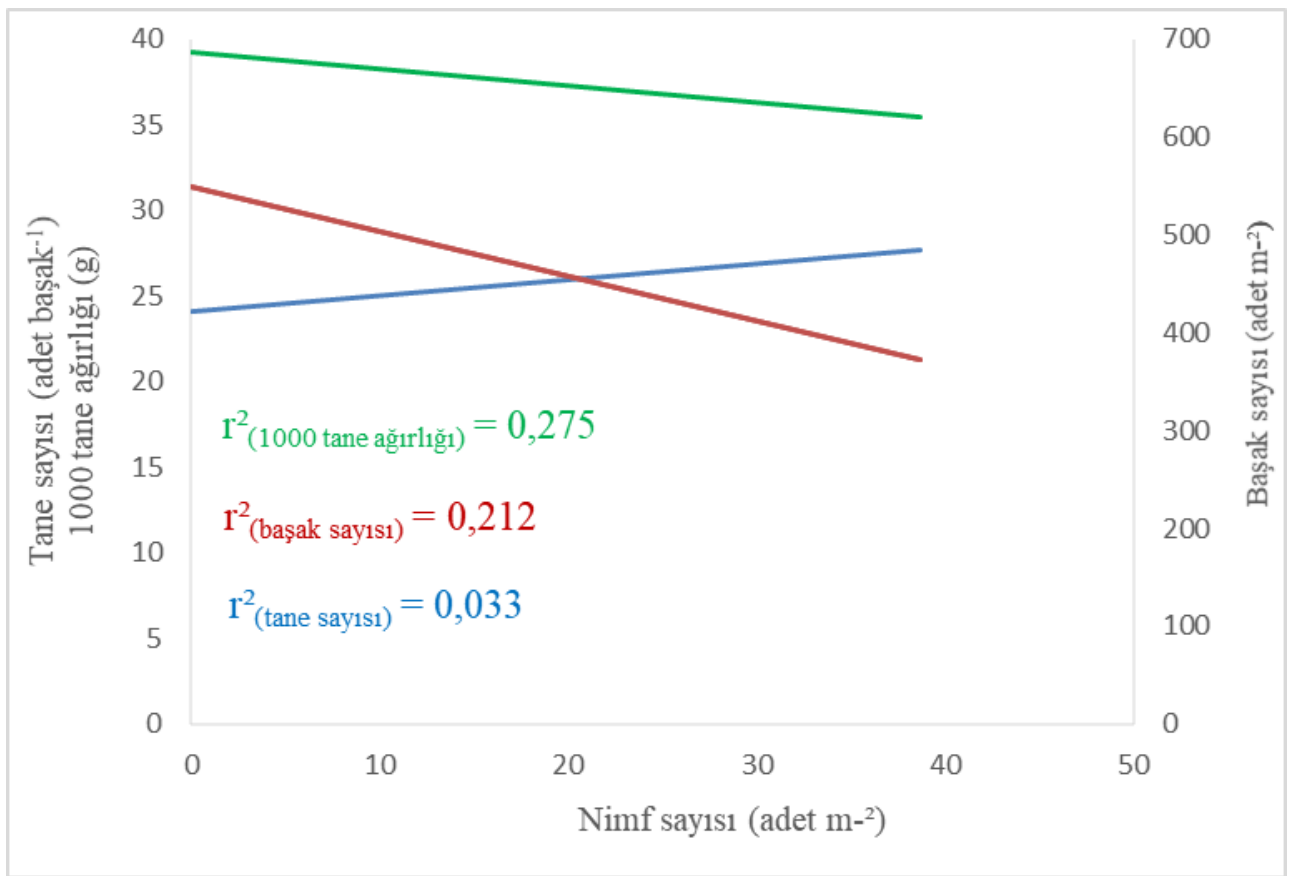

Şekil 7. Geniş alan denemelerinden elde edilen farklı nimf yoğunlukları ile tane, başak sayıları ve 1000 tane ağırlığına ait regresyon doğrusu. 
Özkan M., Babaroğlu N. E., Gökdoğan A., Kan M. ve Koçak E., Bitki Koruma Bülteni, 57 (2), 2017

Tarla koşullarında kafes ve geniş alan denemeleri şeklinde yürüttüğümüz çalışmalar sonucunda Bölgemizde nimf ve erginlerin beslenmeleri sonucunda buğdayda ağırlık bakımından dikkate değer bir ürün kaybının oluşmadığı ortaya konulmuştur. Bölgemiz koşullarına benzer koşullarda süne nimf ve yeni nesil erginlerinin tanede beslenmesi sonucu meydana getirdikleri ağırlık kaybını belirleme çalışmaları incelendiğinde, benzer sonuçların elde edildiği görülmektedir.

Zwölfer (1942), çeşitlere göre değişmekle beraber düşük emgi oranlarında 1000 tane ağırlığında herhangi bir kaybın olmadığı (\%4.7 ve \%5.7 emgi oranlarında ağırlık kayb1 \%0.0) bu nedenle sünenin yüksek yoğunlukta hiç olmazsa orta derecede yoğunlukta görüldüğü alanlardan alınan örneklerle yapılan çalışmalarda ağırlık kaybının görüleceğini bildirmektedir.

Yüksel (1968), sünenin tanede beslenmesi sonucu ağırlıkta meydana getirdiği zarar oranını belirlemek amacıyla yaptığı çalışmalar sonucunda; \%5 emgili taneye kadar zarar görmüş örneklerde ağırlık kaybının çok az olduğunu, bu sebeple ağırlık kaybı hesaplarını \%5 emgili taneden fazla emgili tane içeren örneklerden yaptığını bildirmektedir.

Shurovenkov et al. (1984), Rusya'nın farklı bölgelerinde 1973-1983 yılları arasında süne (E. integriceps)'nin buğdayın verim ve kalitesine olan etkisini belirlemek amacıyla yaptıkları çalışmalar sonucunda; emgi oranının \%4'ün üzerine çıktığında verimde azalmanın meydana geldiğini belirtmişlerdir.

Atlı ve ark. (1988), süne emgisi sonucu zarar görmüş tane oran1 \%7'ye kadar bulunan örneklerde buğdayın fiziksel özelliklerindeki; hektolitre ve 1000 tane ağırlığı ile un verimlerinde meydana gelen azalmanın önemli olmadığının, zarar görmüş tane oranının \%9 ve daha yukarıda olduğunda ise fiziksel özelliklerin önemli düzeyde etkilendiğini bildirmektedir.

Najafi-Mirak (2012), buğday ve tritikale çeşit ve hatlarının süneye olan dayanıklılıklarını araştırdığı tarla koşullarındaki denemelerinde; içerisinde 50 adet bitkinin bulunduğu $0.120 \mathrm{~m}^{2}$ 'lik kafeste $8\left(4++4{ }^{\Uparrow}\right)$ adet kışlamış erginin buğdayın başaklanmasında itibaren 3 hafta beslenmesi sonucu çeşit ve hatlara bağlı olarak \%1.8-13.0 oranında başak zararı oluştuğunu, ancak 1000 tane ağırlığına ve başaktaki tane sayısına herhangi bir etkisinin olmadığını bildirmektedir. Aynı çalışmada söz konusu kafeslerde buğdayın çiçeklenme döneminde itibaren 20-25 gün süre ile 30 adet 3. dönem nimfin gelişmekte olan tane üzerinde beslenmesi sonucu başaktaki tane ağırlığında artışın olduğunu bildirmektedir.

Sanaey et al. (2012), doğal bulaşmanın olduğu (kışlamış ergin yoğunluğu 0.4-12.6 adet $\mathrm{m}^{-2}$ ) tarla koşullarında buğday çeşit ve hatlarının süne (E. integriceps) erginlerine dayanıklılıklarını araştırdığı çalışmalarda zararlı yoğunluğu ile buğdayın bazı özellikleri arasındaki ilişkiyi incelemiş; ergin yoğunluğu ile 1000 tane ağırlı̆̆ arasında $(\mathrm{r}=0.256)$ ve zarar görmüş bitki yoğunluğu arasında $(\mathrm{r}=0.576)$ pozitif yönde bir ilişkinin olduğunu, başak yoğunluğu ile herhangi bir ilişkinin olmadığını bildirmektedir. 
Orta Anadolu Bölgesi’nde buğdayda Avrupa Sünesi (Eurygaster maura L. Hemiptera: Scutelleridae)’nin neden olduğu ürün kayıpları ve ekonomik zarar eşiğinin belirlenmesi

Süne nimf ve yeni nesil erginlerinin tanede beslenmesi sonucu verimde kayıpların olduğunu bildiren çalışmalar incelendiğinde; zararlı yoğunluğu bazı yıllarda ve lokal olarak küçük alanlarda nadir olarak belirlenebilen çok yüksek yoğunluklarda yürütülen çalışmalardan elde edilen sonuçlarda görülmektedir.

Yüksel (1968), sünenin kurtboğazı zararından dolayı tanede verimine etkisini belirlemek amacıyla yaptığ kafes denemelerinde ${ }^{2}$ 'ye 4, 6, 8, 10 ve 20 çift kışlamış ergin koyduğunu ve hesaplamalarını bu yoğunluklardan yaptığını belirtmektedir. Ancak 1956-1961 yıllarında Adıyaman, Diyarbakır, Elazı̆ğ, Mardin, Şanlıurfa, Siirt, Kahramanmaraş, Gaziantep ve Hatay hububat ekim alanlarında yapılan kışlamış ergin sürvey sonuçlarında da görüleceği gibi $\mathrm{m}^{2}$ 'de; $6,8,10$ ve 20 çift kışlamış ergin yoğunluğunun hiç tespit edilmediği, 4 çift sünenin ise sadece 1956 yılında $\% 0.25$; 1957 y1lında $\% 0.56$ ve 1959 yılında da \%0.07 oranında tespit edildiğini bildirmektedir.

Adıgüzel (1981), Güneydoğu Anadolu Bölgesi'nde sünenin popülasyon dalgalanmaları ile ilgili yaptığı çalışmalar sonucunda; 1956-1978 yıllarında 23 yıl süreyle 6 ilde toplam 600.000 ha buğday ekim alanında kışlamış ergin popülasyon yoğunluğunun yıllara göre bölge ortalamasının salgın yıllarında oldukça yüksek $\left(\mathrm{m}^{2}\right.$ de 2 adet) olduğunu bu periyotlar dişında popülasyonun oldukça düşük seviyelerde $\left(\mathrm{m}^{2}\right.$ 'de 1 'in altında) seyrettiğini bildirmektedir.

Kılıç ve ark. (1973) kışlamış erginler ve bunlardan meydana gelen neslin mevsim başından sonuna kadar yaptığı zararı belirlemek amacıyla doğa koşullarında yaptığı kafes denemelerinde $1 \mathrm{~m}^{2}$ 'lik kafeslere 2, 4, 6, 8 ve 10 adet kışlamış ergin koyarak hesaplamaları yapmıştır. Aynı denemede elde edilen emgi oranları incelendiğinde sırasıyla \%19.0, 16.8, 17.9, 36.6 ve 31.4 olduğu görülecektir. Aynı zararı geniş alan çalışmalarında 3.2 (2 adet), 3.6 ve 4 adet kışlamış ergin yoğunluğu olan tarlalarda yürütmüş ve sırasıyla \%19.0, 28.0, 23 ve 27.9 oranında emgili tane tespit etmiştir. Aynı şekilde Kıvan (1999) süne (Eurygaster integriceps) popülasyon yoğunluğu ile meydana getirdiği zarar oranları arasındaki ilişkiyi belirlemek amacıyla 1996 ve 1998 yıllarında yaptığ çalışmasında $\mathrm{m}^{2}$ 'de 8 ve 16 adet kışlamış ergin yoğunluklarında yaptığı çalışma sonucunda 1996 yılında sırasıyla $\% 7.88$ ve 38.38 ; 1998 yılında ise \%6 ve \%22.83 oranında emgiye sahip taneler elde ederek çalışmasını değerlendirmiştir.

Bahrami et al. (2003) Kermanşah-İran kuru tarımın yapıldığı buğday alanlarında ekonomik zarar eşiğini belirlemek amacıyla $1996-98$ yıllarında 3.3 adet $\mathrm{m}^{-2}$ kışlamıș erginin bulunan buğday tarlalarında çalışmalarını yürütmüş, her nimfin yeni nesil oluncaya kadar buğdayın fizyolojik olum dönemine kadar \%0.5 hasat zamanına kadar da \%0.7 oranında emgiye sebep olduğunu bildirmektedir.

Nouri (2007), Nouri et al. (2012), İran'da süne (E. integriceps)'nin buğdayda oluşturduğu verim kaybını ve ekonomik zarar eşiğini belirlemek amaciyla çalışmalarda, $\mathrm{m}^{2}$ 'de $2,4,6,8,10,12,15,17$ ve 20 adet kışlamış ergin olmak üzere 10 farklı yoğunlukta denemelerini sürdürmüş, zararlı yoğunluğu ile verim kaybı arasında pozitif yönde bir ilişkinin olduğunu bildirmektedirler. 
Süne mücadelesi çerçevesinde kışlamış ergin yoğunluğunu belirlemek amacıyla yapılan kıymetlendirme sürveyleri sonucunda; Orta Anadolu Bölgesi'nde 19972010 yıllarına ait süne kışlamış ergin yoğunlukları, $0.10-0.50$ adet $\mathrm{m}^{-2} \% 85.75 ; 0.10$ 0.70 adet $\mathrm{m}^{-} \% 93.74 ; 0.10-1.00$ adet $\mathrm{m}^{-2} \% 98.79 ; 0.10-1.20$ adet $\mathrm{m}^{-2} \% 99.47$ ve 0.10 1.50 adet $\mathrm{m}^{-2} \% 99.91$ oranında olduğu saptanmıştır. Bu yıllarda en yüksek kışlamış ergin yoğunluğu ise 3.20 adet $\mathrm{m}^{-2}$ olarak belirlenmiştir. Aynı dönemdeki ortalama süne emgi oranlarının yıllara göre değişmekle birlikte \%0.89-2.55 oranında olduğunu görülmektedir (Babaroğlu ve ark. 2013).

Verimi belirleyen öğelerden $\mathrm{m}^{2}$ 'deki başak sayısının yıllara göre değişimi o yılın iklim koşullarına göre özellikle yağış miktarına bağlı olarak değişkenlik gösterdiği Çizelge 8'de görülmektedir. Çalışmanın 1. yılı 1997-1998 üretim sezonunda özellikle ilkbahar aylarında mevsim normallerinin üzerinde alınan yağış (ekilişin aldığı toplam yağış miktarı $327.4 \mathrm{~mm}$ ) sonucu $\mathrm{m}^{2}$ 'deki başak sayısı (401.67 adet) yüksek olmuş aynı durum 1998-1999 üretim sezonunda da yaşanmıştır (ekilişin aldığı toplam yağış miktarı $286.7 \mathrm{~mm}, \mathrm{~m}^{2}$ 'deki başak sayıs1 527.99 adet). Başak sayısının (272.14 adet $\mathrm{m}^{-2}$ ) az olduğu 2000-2001 üretim sezonunda ise ekilişin aldığ toplam yağış miktarının 145.4 mm olduğu dikkati çekmektedir. 2002-2003 üretim sezonunda ise $217.8 \mathrm{~mm}$ yağış olmuş $\mathrm{m}^{2}$ 'de 332.53 adet başak elde edilmiştir. $\mathrm{Bu}$ sonuçlar yağış olmayan ve kurak geçen yıllarda $\mathrm{m}^{2}$ 'de bitki sayısının daha az olduğunu göstermektedir (Çizelge 11).

Tanede ağırlık kaybının oluşmasındaki önemli kriterlerden birisi de tanenin zarar gördüğü fenolojik dönemdir. Erken dönemde yani süt olum, sarı olum döneminde zarar görmeleri durumunda tanedeki ağırlık kaybının daha belirgin olduğu belirtilmektedir (Yüksel 1968). Çalışmaların yürütüldüğü yıllarda (1998-2005) bölgemizde 1. dönem nimflerin buğdayın çiçeklenme sonu-tane oluşum döneminde görüldüğü ve bu dönemde nimflerin yumurtanın bırakıldığı yakın yerlerde bulunduğu belirlenmiştir. Buğdayın süt olum döneminde görülmeye başlayan 2 . dönem nimfler başaklarda beslenmeye başlamaktadırlar. Asıl zararı oluşturan 3. dönem nimflerin süt olum sonu-sarı olum, 4. dönem nimflerin sarı olum, 5. dönem nimflerin sarı olum sonu-sert olum başı ve yeni nesil erginlerin de sert olum dönemlerinde görüldügü belirlenmiştir. Aynı bölgede Memişoğlu (1985)'nun yaptığı çalışmalarda da benzer sonuçlar elde edilmiştir.

Yüksel (1968), Güneydoğu Anadolu Bölgesi’nde Floransa çeşidinde yapılan çalışmalarda ağırlıklı olarak 1. dönem nimfler sapa kalkma-başaklanma; 2. dönem nimfler başaklanma-çiçek; 3. dönem nimfler çiçeklenme-süt olum; 4. dönem nimfler süt olum; 5. dönem nimfler süt olum sonu ve yeni nesil erginler sarı olum-hasat dönemlerinde görülmektedirler. Yine aynı bölgede sert buğday ile yaptıkları çalışmaların sonucunda ise 1. dönem sapa kalkma; 2. dönem başaklanma; 3. dönem çiçeklenme; 4. dönem çiçeklenme sonu; 5. dönem süt olum sonu ve yeni nesil erginler ise süt olum sonu- hasat zamanlarında görülmekte olduğunu bildirmektedir. 
Orta Anadolu Bölgesi'nde buğdayda Avrupa Sünesi (Eurygaster maura L. Hemiptera: Scutelleridae)'nin neden olduğu ürün kayıpları ve ekonomik zarar eşiğinin belirlenmesi

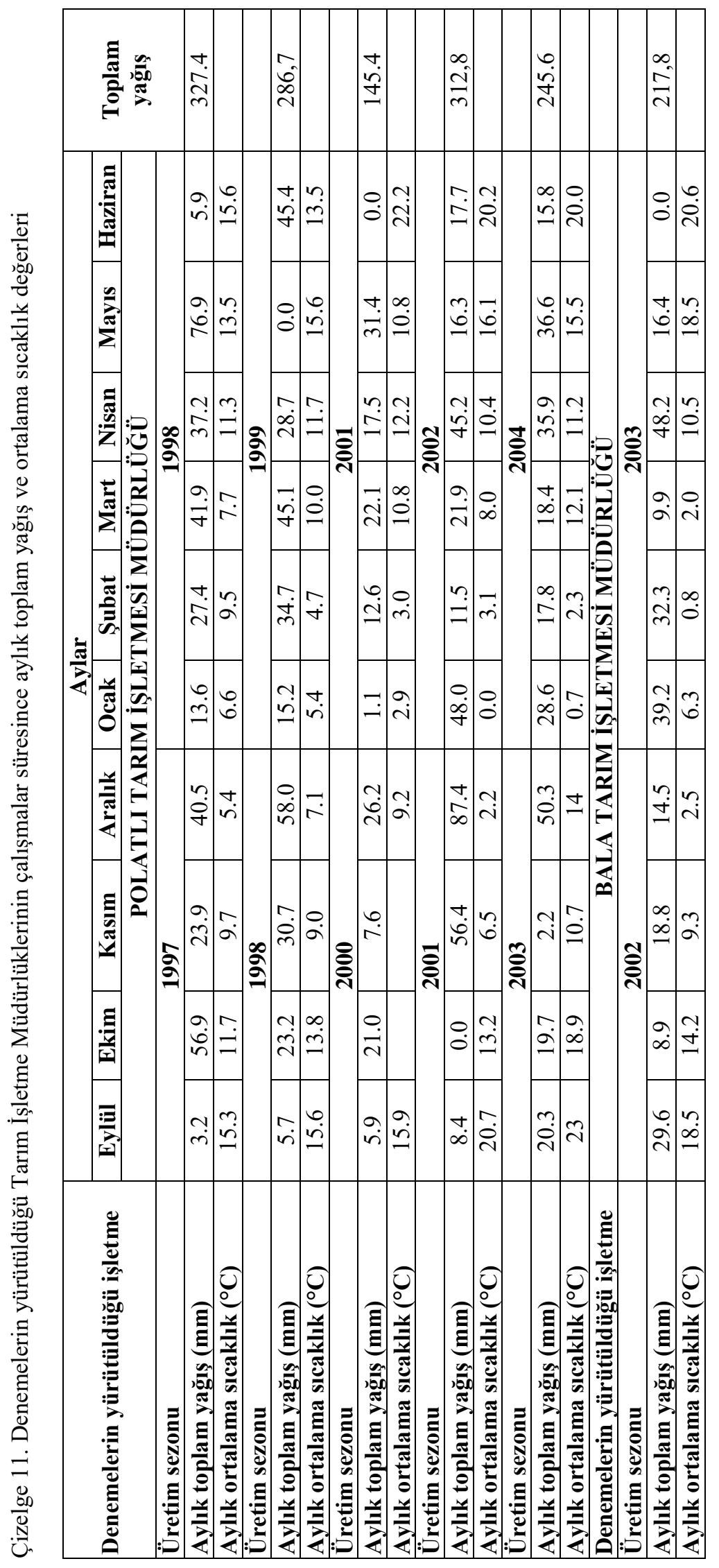




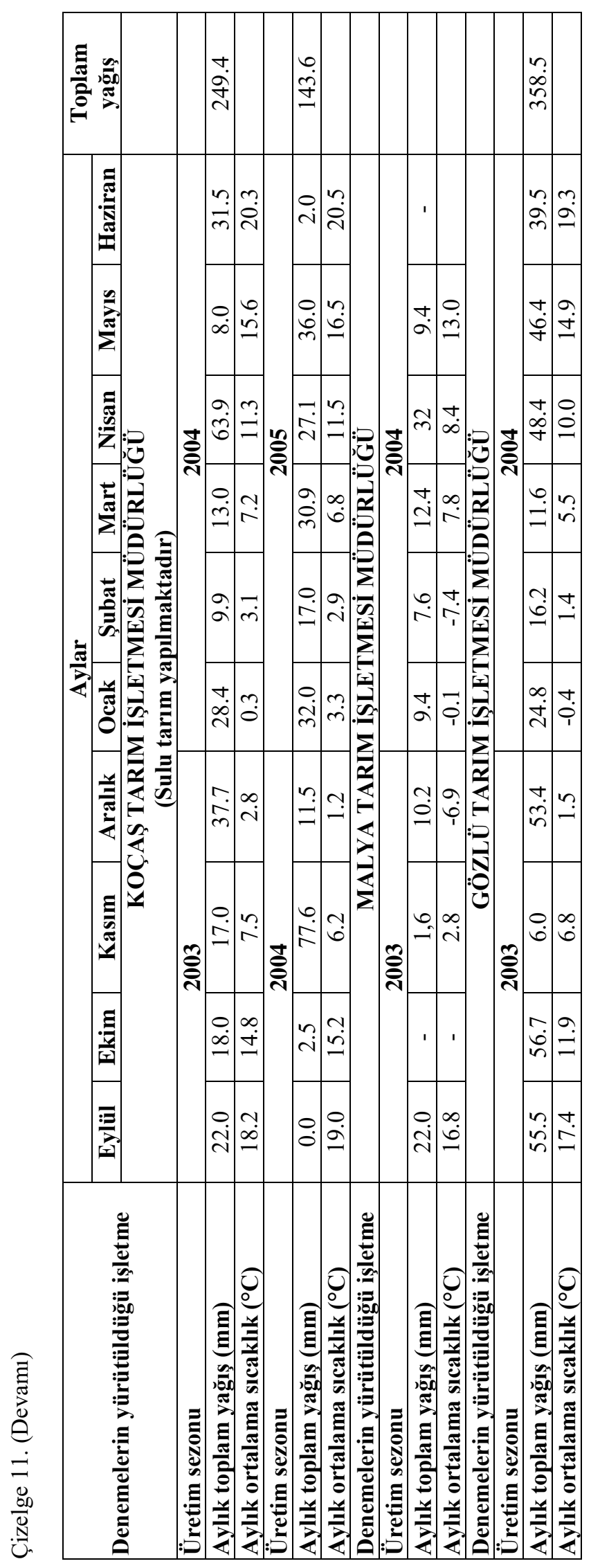


Orta Anadolu Bölgesi’nde buğdayda Avrupa Sünesi (Eurygaster maura L. Hemiptera: Scutelleridae)’nin neden olduğu ürün kayıpları ve ekonomik zarar eşiğinin belirlenmesi

Kılıç ve ark. (1973) Güneydoğu Anadolu Bölgesi’nde E. integriceps’in sadece kışlamış ergin, 4. ve 5. dönem nimfleri ve yeni nesil erginlerinin aktif dönemlerinde zararlı olduklarını, Budak (1976), yine aynı bölgede sünenin 3. dönem nimf devresinden itibaren zararlı olmaya başladığını bildirmektedirler.

Vojdani (1961), Kaliforniya'da E. amerinda, E. minidoka ve E. shoshone türlerinin olduğunu 1. dönem nimflerin beslenmeksizin yumurta kabuğu çevresinde bulunduğunu, 2. dönemin sonu itibariyle bitkinin üst kısımlarına tırmanarak beslenmeye başladıklarını ve yoğun beslenmenin 3. dönemden itibaren başladığını bu dönemde buğdayın süt olum- sarı olum döneminde olduğunu bildirmektedir.

Bölgemizde, sünenin asıl ağırlık kaybını meydana getiren 4.-5. dönem nimfleri ile yeni nesil ergin dönemleri buğdayın fenolojik olarak geç (sarı olum-sert olum) dönemlerinden itibaren görülmeye başladığından, ağırlıkta meydana gelen kayıpların yüksek olduğu buğdayın erken (çiçeklenme-süt olum) dönemlerinde 4.-5. dönem nimfleri ile yeni nesil erginlerin görüldüğü diğer bölgelere göre çok daha düşük olmaktadır.

\subsection{Kalite (nitelik) yönünden meydana gelen zarar}

Sünenin bir diğer zararı ise nimf ve yeni nesil erginlerinin tanede beslenmeleri sonucu buğdayın teknolojik kalitesinde bozulmalara sebep olmasıdır. Kalitede görülen bozulmanın başlıca sebebi tanede beslenirken buğday proteinlerini, özellikle glüten proteinlerini parçalayan proteolitik ve amilolitik enzimler içeren salgının neden olduğu enzimatik faaliyettir.

Fizikokimyasal (teknolojik) buğday özellikleri sadece süne zararından değil çeşidin genetik özellikleri, iklim koşulları, toprak özellikleri, gübreleme ve tarımsal uygulamalar ve tahıl hastalıkları tarafından da önemli ölçüde etkilenmektedir. Farklı araştırmacılar tarafindan değişik çeşitler ile yapılan çalışmalar incelendiğinde; kalitenin bozulduğu kabul edilebilir üst emgi oranındaki farklılıkların yukarıda belirtilen koşullara bağlı olarak değiştiği görülecektir.

Zwöfer (1942), süne emgisinin \%5 ve üzerindeki oranlara sahip olan buğdaylardan elde edilen unlarla yapılan ekmeklerde kendini hissettirdiğini de bildirmektedir.

Yüksel (1969), kımıl ve sünenin glüten oranı yüksek olan (\%41.7) Köse 225/39 yumuşak buğday çeşidinde \%5'lik zararın buğday un ve ekmeklik özelliğini bozarak hemen hemen işe yaramaz bir hale getirdiğini bildirmektedir.

Gospodinov and Atanasova (1975), Bulgaristan'da 63 adet buğday çeşidinde yaptığ1 kalite analizleri sonucunda; $E$. integriceps'in zarar yapması durumunda emgili tane oranı \%4'ü, E. maura, E. austriaca ve A. acuminat'nın zarar yapması durumunda \%6'y1 geçtiğinde teknolojik özelliklerin bozulduğunu bildirmektedirler.

Mikhilova and Shurovenkov (1977), Rusya'da yaptıkları çalışmalarda süne (E. integriceps) nimf+YNE'lerin sert ve yumuşak buğdaylarda beslenmeleri sonucunda 
Özkan M., Babaroğlu N. E., Gökdoğan A., Kan M. ve Koçak E., Bitki Koruma Bülteni, 57 (2), 2017

tanenin glüten içeriğinde azalmaların meydana geldiğini, sert buğdaylarda emgi oranının \%8 ve üzerine çıktığında kalitenin bozulduğunu vurgulamışlardır.

Gotsova and Kontev (1981), 1978-1979 yıllarında Bulgaristan'da, \%3, 6 ve 10 emgi oranına sahip 14 buğday çeşidinden elde ettiği unların ekmek yapım kalitesini incelediği çalışması sonucunda; süne tarafindan zarara uğratılmış tanelerden elde edilen unların ekmek yapım kalitesi çeşitlerin teknolojik kalitesine bağlı olarak değiştiğini, her ne kadar hamurun işlenmesi zor olsa da \%3 emgi oranına kadar yüksek kaliteli çeşitlerden elde edilen un ile karışım yapmadan \%5-6 oranında emgili tanelerden elde edilen orta derecede kaliteye sahip çeşitlerden elde edilen unlar ile iyi kalitede ekmeğin yapılabildiğini bildirmektedir.

Emel'yanov (1982), glütenlerinin fiziksel özellikleri ve zarar derecesi (emgi oranı) aynı olan ekmeklik kışlık buğday çeşitlerinden Saratovskaya 8'in Mironovsky 808'e göre daha iyi glüten kalitesine, un gücüne ve pişirme kalitesine sahip olduğunu bildirmektedir.

Shurovenkov et al. (1984), Rusya'nın farklı bölgelerinde 1973-1983 yılları arasında Süne (E. integriceps)'nin buğdayın verim ve kalitesine olan etkisini belirlemek amacıyla yaptıkları çalışmalar sonucunda; buğdayın verim ve kalitesindeki düşüşlerin ana sebebinin süne olmadığını, emgili tane oranının \%4 olduğunda kalitede herhangi bir değişimin olmadığını bu oranın \%7'nin üzerine çıtığında bozulmanın başladığını bildirmektedirler.

El Haramain et al. (1984), \%2-3 emgili buğdaylarda elde edilen unların ekmek olma özelliğini düştüğünü bildirmektedir.

Atlı (1987), Trakya Bölgesi’nden alınan emgi oranının \%1.90-41.5 arasında değişen 57 adet buğday örneğinde yaptığı çalışma sonucunda kabul edilebilir üst emgi sınırının, protein oran $1 \% 11.4$ 'ten az olan buğday çeşitlerinde $\% 3.00$, protein oranı $\% 11.4$ 'ten fazla olan çeşitlerde ise $\% 5$ olduğunu bildirmektedir.

Josephides (1994), \%5'in üzerinde emgili tanelerden yapılan unların teknolojik özelliklerinin bozulduğunu belirtmektedir.

Karababa and Ozan (1998), emgili tane oranı \%5'in üzerine çıtığında kalitedeki azalmanın önemli olduğunu, yüksek oranda emgili tane içeren buğdaylardan yapılan unların ekmek yapına uygun olmadığını bildirmektedir.

Petrova (2002), makarnalık buğdaylarda kabul edilebilir üst emgi oranı sınır çeşitlere göre değiştiği, zayıf glutenli çeşitlerde $\% 2$ emgili tane kabul edilirken yüksek glüten içeren çeşitlerde bu oranın \%5'e yükseldiğini bildirmektedir.

Saric et al. (2003), sarı olum döneminde zarar görmüş tanelerin buğday kalitesinde önemli düşmeler olduğunu, sağlam tanelere göre özlerinin azaldığını, emgili tane oran $\% 6$ olduğunda 1000 tane ağırlı̆̆ , sedimantasyon değeri ve glüten içeriğinin düştüğünü bildirmektedir. Ağır böcek zararına maruz kalan buğdayların ekmeklik 
Orta Anadolu Bölgesi’nde buğdayda Avrupa Sünesi (Eurygaster maura L. Hemiptera: Scutelleridae)’nin neden olduğu ürün kayıpları ve ekonomik zarar eşiğinin belirlenmesi

kaliteleri ve reolojik özellikleri önemli ölçüde etkilendiğinden bunlardan ekmek yapmanın mümkün olmadığını bildirmektedirler.

Aden et al. (2004), sünenin tane oluşum dönemindeki zararı sonucu $\% 5$ emgi oranında buğdayın ekmek olma özelliğini yitirdiğini belirtmektedir.

Özderen ve ark. (2008), süne zararı sebebiyle gluten kalitesinde bozulma olduğunu, genel olarak makarnalık buğdayların ekmeklik buğdaylara göre daha yüksek süne zararını tolere edebildiğini bildirmektedir.

Şanal (2009), çeşitlerin kalitelerine göre farklı emgi oranlarında farklı toleranslar gösterdiğini, protein kalitesi iyi olan çeşitlerin \%5-6 emgili tane içermeleri durumunda kalitelerini bozmazken, düşük protein kalitesine sahip çeşitlerin \%1-2 emgili tane içermelerinde bile kalitelerinin bozulduğunun ve işlenemediklerini bildirmektedirler.

Atlı ve ark. (2010), makarna sanayinin son yıllarda kullanmaya başladığı yoğurma teknolojisi makarnalık buğdayda daha fazla ve kaliteli glüten yapısını gerektirdiğini, bu yeni teknolojiyi kullanan makarna fabrikalarında \%1.5-2.0 süne emgi zararının bile makarna kalitesini bozduğunu belirtmektedirler.

Dizlek ve İslamoğlu (2010) süne emgili tane oranının unların ekmeklik niteliklerine etkilerini incelediği çalışmasında, Golia buğday çeşidinde ekmek yapımında kritik süne emgi düzeyinin \%4 olduğunu, bu düzeye kadar emgili buğdayların ekmeklik niteliklerinde belirgin bir gerilemenin olmadığı hatta yer yer iyileşme olduğunu bildirmektedir. Aynı araştırıcı Sagittario çeşidinde ise $\% 2$ emgi oranı da dahil olmak üzere ekmeklik niteliklerinde belirgin gerilemelerin ortaya çıktığı, bu sebeple Sagittario çeşidi için kritik emgi düzeyinin \%2 olduğunu bildirmektedir.

Argun ve Elgün (2015), emgili tane seviyeleri \%3'e kadar, enzimatik katkı ile ekmek hacim özelliklerine zarar vermezken, iç özelliklerine özellikle Maillard reaksiyonu sonucu renk esmerleşmesi şeklinde zararlı olmuştur. Yüksek emgi oranlarında ise tüm kalite özelliklerinde hızlı bir düşüş gözlenmiştir. Emgi seviyesi \%3 düzeyindeyken normal düzeyde artan amilaz aktivitesinden dolayı hacim artarken, $\% 5$ ve 10 gibi yüksek emgi seviyelerinde aşırı proteolitik ve amilolitik aktivite artışıyla tüm ekmek özelliklerinin değer kaybettiğini belirtmektedirler.

Blandino et al. (2015), hem makarnalık ve hem de ekmeklik buğday çeşitlerinin kalitesinin \%2.5 emgi oranında etkilendiğini bildirmektedir.

Dizlek and Özer (2016), Golia ve Sagittario buğday çeşitlerinde süne emgili tane oranının, unların ekmeklik niteliklerine etkilerini incelediği çalışmasında emgili tane oranı \% 2'den başlamak üzere unların kalitesinde düşmelerin başladığını, emgili tane oranı \%4'ün üzerine çıttı̆ıında her iki çeşitte de un kalitesinin önemli ölçüde azaldığını bildirmektedir.

Tüm bu çalışmalar incelendiğinde, buğdayın teknolojik kalitesini bozan kabul edilebilir emgili tane oranının çeşitlerin genetik özellikleri, iklim koşulları, toprak 
özellikleri ve tarımsal uygulamalara bağlı olarak değişmekle beraber, \%2-5 oranları arasında olduğu görülecektir. Ayrıca “Süne İzleme ve Yönlendirme Komitesi” kararı gereğince kabul edilebilir süne emgi oranı \%3.5 olarak belirlenmiştir (Anonim 2006). "Toprak Mahsulleri Ofisi Hububat Alım ve Satış Esaslarına İliş̧kin Uygulama Yönetmeliğì”, EK:7'de verilen süne ve kımıl tahribatına uğramış tane oranına göre yapılacak fiyat indirimleri alım yıllarına göre değişmekle birlikte, yukarıda sözü edilen karar gereğince \%3.5'in üzerinde emgi oranına sahip buğdayların fiyatlandırmasında büyük oranda (yaklaşık \%16 oranında) indirim yapmaktadır (Çizelge 12). Ticaret borsaları da "Süne İzleme ve Yönlendirme Komitesi” kararına göre hazırlanan TS 2974 buğday standartı gereğince; kabul edilebilir üst emgi oranını \%3.5 baz alarak buğday alımını gerçekleştirmektedir.

Yukarıda verilen çalışmalar ile "Toprak Mahsulleri Ofisi Hububat Alım ve Satış Esaslarına İlişkin Uygulama Yönetmeliğ̣”" birlikte değerlendirildiğinde kabul edilebilir emgili tane oran $1 \% 2,3,3.5$, 4 ve 5 temel alınarak, bu emgili tane oranlarını oluşturan nimf sayıları ortaya konulmaya çalışılmıştır. Bu amaçla ikili lojistik regresyon analizinden yararlanılmıştır.

Çizelge 10. Süne ve kımıl tahribatına uğramış tane oranına göre yapılacak fiyat indirimleri

\begin{tabular}{|c|c|c|c|}
\hline \multirow{2}{*}{ Ürün } & \multirow{2}{*}{ Tahribat Oranı (\% G) } & \multicolumn{2}{|c|}{ Fiyatta yapılacak indirim (\%) } \\
\hline & & Yönetmelik & 2015-2016 \\
\hline \multirow{7}{*}{$\begin{array}{c}\text { Makarnalik } \\
\text { ve Ekmeklik } \\
\text { Buğday } \\
\text { 2010/11- } \\
\text { 2016/17 }\end{array}$} & $0.0-1.0$ & \multicolumn{2}{|c|}{ İndirim uygulanmaz } \\
\hline & $1.1-1.5$ & 0.5 & 0.5 \\
\hline & $1.6-2.0$ & 1.0 & 1.5 \\
\hline & $2.1-2.5$ & 3.0 & 4.0 \\
\hline & $2.6-3.0$ & 4.0 & 5.5 \\
\hline & $3.1-3.5$ & 5.0 & 7.0 \\
\hline & $\begin{array}{l}\text { \%3.6-10.0 arasında olan makarnalık } \\
\text { buğdaylar; düşük vasıflı makarnalık buğday } \\
\text { fiyatı ile satın alınır. } \\
\% 10.1-14 \text { arasında olan makarnalık } \\
\text { buğdaylar ve \%3.6-14 arasında olan } \\
\text { ekmeklik buğdaylar ise ekmeklik buğdaylar } \\
\text { asgari alım fiyatı ile satın alınır. } \\
\% 14 \text { 'ün üzeri satın alınmaz }\end{array}$ & & \\
\hline
\end{tabular}

İkili lojistik regresyon analizinden yararlanılarak oluşturulan Çizelgeler (13-17) incelendiğinde üç değişkenli $\left(\mathrm{m}^{2}\right.$ 'deki başak ve nimf sayıları ile başaktaki tane sayıs1) modelin kabul edilebilir uyuma sahip olduğu görülecektir (HosmerLemeshow testi). Üç değişkenli modelinin kabul edilebilir üst emgi sınırı \%3, 3.5, 4 ve 5 olarak alındığında kabul edilebilir uyuma sahip olmasına karşın, kabul edilebilir üst emgi sınırı $\% 2$ olarak alındığında başaktaki tane sayısının modele katkısının önemsiz olduğu belirlenmiştir. Her ne kadar başaktaki tane sayısının modele katkısı önemsiz bulunmuş ise de verimini belirleyen temel öğelerden biri olduğundan modele dahil edilmiştir. 
Orta Anadolu Bölgesi’nde buğdayda Avrupa Sünesi (Eurygaster maura L. Hemiptera: Scutelleridae)’nin neden olduğu ürün kayıpları ve ekonomik zarar eşiğinin belirlenmesi

Kabul edilebilir üst emgi sınır \%2 olarak alındığında; bağımsız değişkenler; $\mathrm{m}^{2}$ 'deki başak ve nimf sayısı ile başaktaki tane sayısı, emgi oranındaki değişimi, Cox-Snell'e göre \%58.1; Nagelkerke'ye göre \%78.6 oranında açıklamaktadır. Çizelgede 13'de görüleceği üzere başak ve tane sayılarında meydana gelecek artış sonucunda emgi oranında azalmanın olacağ $\left[\operatorname{Exp}(B)_{\text {başak sayısı }}=0.987\right.$; $\left.\operatorname{Exp}(B)_{\text {tane sayısı }}=0.945\right]$, bunun aksine nimf sayısında oluşacak artışa paralel olarak emgi oranın da artacağı belirlenmiştir [Exp (B) $\left.)_{\text {nimf sayısı }}=2.576\right]$.

Modelin sınıflandırma durumu incelendiğinde; \%2'in altında emgiye sahip olanları $\% 93.50 ; \% 2$ ve üzerinde olanları da $\% 92.80$ oranında doğru tahmin ettiği, genel olarak doğru tahmin yüzdesinin de 93.00 olduğu görülecektir.

Çizelge 11. Kabul edilebilir üst emgi oranı \%2 alındığında lojistik regresyon analiz sonuçları

\begin{tabular}{|c|c|c|c|c|c|c|}
\hline Açıklayıcı değiş̧kenler & B & $\begin{array}{c}\text { Standart } \\
\text { hata }\end{array}$ & Wald & $\begin{array}{c}\text { Serbestlik } \\
\text { derecesi }\end{array}$ & $\begin{array}{c}\text { Önem } \\
\text { seviyesi }\end{array}$ & $\operatorname{Exp}(B)$ \\
\hline Başak sayıs1 (adet m²) & -0.014 & 0.004 & 12.315 & 1 & $0.000 * * *$ & 0.987 \\
\hline Tane sayıs1 (adet başak ${ }^{-1}$ ) & -0.056 & 0.107 & 0.276 & 1 & 0.600 & 0.945 \\
\hline Nimf sayısı (adet $\mathrm{m}^{-2}$ ) & 0.946 & 0.210 & 20.255 & 1 & $0.000 * * *$ & 2.576 \\
\hline Sabit & 3.770 & 2.807 & 1.804 & 1 & 0.179 & 43.393 \\
\hline Gözlem sayıs1 & \multicolumn{6}{|l|}{115} \\
\hline Log-Likelihoodvalue & \multicolumn{6}{|l|}{54.696} \\
\hline Cox\&Snell R ${ }^{2}$ & \multicolumn{6}{|l|}{0.581} \\
\hline Nagelkerke $\mathrm{R}^{2}$ & \multicolumn{6}{|l|}{0.786} \\
\hline Doğru sınıflandırma yüzdesi & \\
\hline Emgi oran $1(\%)<2$ & \multicolumn{6}{|l|}{93.5} \\
\hline Emgi oran1 $(\%) \geq 2$ & \multicolumn{6}{|l|}{92.8} \\
\hline Toplam doğru sınıflandırma yüzdesi & \multicolumn{6}{|l|}{93.0} \\
\hline HosmerandLemeshow Test & \multicolumn{6}{|c|}{$\mathrm{X}^{2}=11.454 ; \mathrm{df}=8 ; \mathrm{p}=0.177$} \\
\hline
\end{tabular}

*** \%99 önem seviyesinde anlamlılı̆̆ belirtmektedir.

** \%95 önem seviyesinde anlamlılığ 1 belirtmektedir.

* \%90 önem seviyesinde anlamlılığı belirtmektedir.

Çizelge 6'daki verilerle oluşturulan olasılık formülü $\left(\boldsymbol{p}_{2}\right)$ yardımıyla hesaplanan; farklı başak ve tane sayılarında $\% 2$ ve üzerinde emgi meydana getirecek nimf sayıları EK 1'de verilmiştir.

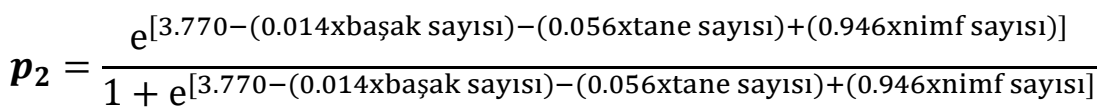

Kabul edilebilir üst emgi sınırı \%3'e çıkarıldı̆̆ında bağımsız değişkenler, emgi oranındaki değişimi, Cox-Snell'e göre \%56.8; Nagelkerke'ye göre \%75.7 oranında açıkladığı görülecektir (Çizelge 14). 
Çizelge 12. Kabul edilebilir üst emgi oranı \%3 alındığında lojistik regresyon analiz sonuçları

\begin{tabular}{|c|c|c|c|c|c|c|}
\hline Açıklayıcı değiş̧kenler & $\mathbf{B}$ & $\begin{array}{c}\text { Standart } \\
\text { hata }\end{array}$ & Wald & $\begin{array}{c}\text { Serbestlik } \\
\text { derecesi }\end{array}$ & $\begin{array}{c}\text { Önem } \\
\text { seviyesi }\end{array}$ & $\operatorname{Exp}(B)$ \\
\hline Başak sayısı (adet m²) & -0.013 & 0.004 & 13.754 & 1 & $0.000 * * *$ & 0.987 \\
\hline Tane sayıs1 (adet başak ${ }^{-1}$ ) & -0.180 & 0.096 & 3.497 & 1 & $0.061^{*}$ & 0.835 \\
\hline Nimf sayıs1 (adet m²) & 0.628 & 0.125 & 25.412 & 1 & $0.000 * * *$ & 1.873 \\
\hline Sabit & 6.874 & 2.628 & 6.840 & 1 & $0.009 * * *$ & 966.781 \\
\hline Gözlem say1s1 & \multicolumn{6}{|l|}{115} \\
\hline Log-Likelihoodvalue & \multicolumn{6}{|l|}{62.923} \\
\hline Cox\&Snell R ${ }^{2}$ & \multicolumn{6}{|l|}{0.568} \\
\hline Nagelkerke $\mathrm{R}^{2}$ & \multicolumn{6}{|l|}{0.757} \\
\hline Doğru sınıflandırma yüzdesi & \\
\hline Emgi oran $1(\%)<3$ & \multicolumn{6}{|l|}{89.5} \\
\hline Emgi oran $1(\%) \geq 3$ & \multicolumn{6}{|l|}{89.7} \\
\hline Toplam doğru sınıflandırma yüzdesi & \multicolumn{6}{|c|}{89.6} \\
\hline HosmerandLemeshow Test & \multicolumn{6}{|c|}{$X^{2}=5.667 ; \mathrm{df}=8 ; \mathrm{p}=0.684$} \\
\hline
\end{tabular}

Çizelge 15-17 incelendiğinde kabul edilebilir emgi oranı \%3,5 olduğunda, CoxSnell'e göre \%56.4; Nagelkerke'ye göre \%75.6 oranında, \%4 olduğunda, CoxSnell'e göre $\% 57.6$; Nagelkerke'ye göre $\% 77.7$ oranında ve $\% 5$ olduğunda da, CoxSnell'e göre \%60.1; Nagelkerke'ye göre \%82.9 oranında açıkladığı belirlenmiştir. Çizelgeler 10-17'da da görüleceği üzere başak ve tane sayılarında meydana gelecek artış sonucunda emgi oranında azalmanın olacağı, nimf sayısında oluşacak artışa paralel olarak emgi oranın da artacağı belirlenmiştir [Exp (B) nimf sayısı]. Modellerin sınıflandırma durumu incelendiğinde; kabul edilebilir üst emgi sınır altında emgiye sahip olanların \%89.50-94.70; ve üzerinde olanların da \%82.50-89.7 oranında doğru tahmin ettiği, genel olarak doğru tahmin yüzdesinin de \%89.6-91.3 olduğu görülecektir. 
Orta Anadolu Bölgesi’nde buğdayda Avrupa Sünesi (Eurygaster maura L. Hemiptera: Scutelleridae)’nin neden olduğu ürün kayıpları ve ekonomik zarar eşiğinin belirlenmesi

Çizelge 13. Kabul edilebilir üst emgi oranı \%3.5 alındığında lojistik regresyon analiz sonuçları

\begin{tabular}{|c|c|c|c|c|c|c|}
\hline Açıklayıcı değişkenler & B & $\begin{array}{l}\text { Standar } \\
\text { t hata }\end{array}$ & Wald & $\begin{array}{c}\text { Serbestli } \\
\mathbf{k} \\
\text { derecesi }\end{array}$ & $\begin{array}{c}\text { Önem } \\
\text { seviyesi }\end{array}$ & $\operatorname{Exp}(B)$ \\
\hline Başak sayısı (adet m²) & $\begin{array}{c}- \\
0.015 \\
\end{array}$ & 0.004 & $\begin{array}{c}15.17 \\
8 \\
\end{array}$ & 1 & $\begin{array}{c}0.000 * * \\
*\end{array}$ & 0.958 \\
\hline Tane sayıs1 (adet başak ${ }^{-1}$ ) & $\begin{array}{c}- \\
0.173\end{array}$ & 0.097 & 3.174 & 1 & $0.075^{*}$ & 0.841 \\
\hline Nimf sayıs1 (adet $\mathrm{m}^{-2}$ ) & 0.558 & 0.119 & $\begin{array}{c}21.89 \\
2\end{array}$ & 1 & $\begin{array}{c}0.000^{* *} \\
*\end{array}$ & 1.747 \\
\hline Sabit & 6.794 & 2.640 & 6.623 & 1 & $\begin{array}{c}0.010^{* *} \\
*\end{array}$ & $\begin{array}{c}892.23 \\
1\end{array}$ \\
\hline Gözlem sayıs1 & & \multicolumn{5}{|l|}{115} \\
\hline Log-Likelihoodvalue & & \multicolumn{5}{|l|}{62.045} \\
\hline Cox\&Snell $\mathrm{R}^{2}$ & & \multicolumn{5}{|l|}{0.564} \\
\hline Nagelkerke $\mathrm{R}^{2}$ & & \multicolumn{5}{|l|}{0.756} \\
\hline \multicolumn{7}{|l|}{ Doğru sınıflandırma yüzdesi } \\
\hline Emgi oran1 $(\%)<3.5$ & & \multicolumn{5}{|l|}{92.39} \\
\hline Emgi oran $1(\%) \geq 3.5$ & & \multicolumn{5}{|l|}{88.00} \\
\hline $\begin{array}{l}\text { Toplam doğru sınıflandırma } \\
\text { yüzdesi }\end{array}$ & & \multicolumn{5}{|l|}{90.40} \\
\hline HosmerandLemeshow Test & & \multicolumn{5}{|c|}{$X^{2}=5.862 ; d f=8 ; p=0.663$} \\
\hline
\end{tabular}

*** \%99 önem seviyesinde anlamlılı̆̆ belirtmektedir.

** \%95 önem seviyesinde anlamlılığ belirtmektedir.

* \%90 önem seviyesinde anlamlılığı belirtmektedir.

Çizelge 14. Kabul edilebilir üst emgi oranı \%4 alındığında lojistik regresyon analiz sonuçları

\begin{tabular}{|c|c|c|c|c|c|c|}
\hline Açıklayıcı değişkenler & B & $\begin{array}{c}\text { Standart } \\
\text { hata }\end{array}$ & Wald & $\begin{array}{c}\text { Serbestlik } \\
\text { derecesi }\end{array}$ & $\begin{array}{c}\text { Önem } \\
\text { seviyesi }\end{array}$ & $\operatorname{Exp}(B)$ \\
\hline Başak sayısı (adet m²) & -0.018 & 0.004 & 16.400 & 1 & $0.000^{* * *}$ & 0.982 \\
\hline Tane sayısı (adet başak ${ }^{-1}$ ) & -0.187 & 0.104 & 3.202 & 1 & $0.074 *$ & 0.830 \\
\hline Nimf sayıs1 (adet $\mathrm{m}^{-2}$ ) & 0.549 & 0.124 & 19.633 & 1 & $0.000 * * *$ & 1.732 \\
\hline Sabit & 8.101 & 2.874 & 7.943 & 1 & $0.005 * * *$ & 3297.743 \\
\hline Gözlem say1s1 & \multicolumn{6}{|l|}{115} \\
\hline Log-Likelihoodvalue & \multicolumn{6}{|l|}{56.858} \\
\hline Cox\&Snell R ${ }^{2}$ & \multicolumn{6}{|l|}{0.576} \\
\hline Nagelkerke $\mathrm{R}^{2}$ & \multicolumn{6}{|l|}{0.777} \\
\hline Doğru sınıflandırma yüzdesi & \multicolumn{6}{|l|}{ 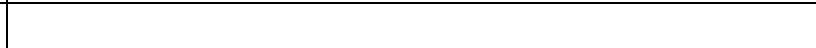 } \\
\hline Emgi oran1 $(\%)<4$ & \multicolumn{6}{|l|}{94.1} \\
\hline Emgi oran1 $(\%) \geq 4$ & \multicolumn{6}{|l|}{87.2} \\
\hline Toplam doğru sınıflandırma yüzdesi & \multicolumn{6}{|l|}{91.3} \\
\hline HosmerandLemeshow Test & \multicolumn{6}{|c|}{$\mathrm{X}^{2}=13.843 ; \mathrm{df}=8 ; \mathrm{p}=0.860$} \\
\hline
\end{tabular}

*** \%99 önem seviyesinde anlamlılığ belirtmektedir.

** \%95 önem seviyesinde anlamlılığ 1 belirtmektedir.

* \%90 önem seviyesinde anlamlılığı belirtmektedir. 
Özkan M., Babaroğlu N. E., Gökdoğan A., Kan M. ve Koçak E., Bitki Koruma Bülteni, 57 (2), 2017

Çizelge 15. Kabul edilebilir üst emgi oranı $\% 5$ alındığında lojistik regresyon analiz sonuçları

\begin{tabular}{|c|c|c|c|c|c|c|}
\hline Açıklayıcı değişkenler & B & $\begin{array}{c}\text { Standart } \\
\text { hata }\end{array}$ & Wald & \begin{tabular}{|c} 
Serbestlik \\
derecesi
\end{tabular} & $\begin{array}{c}\text { Önem } \\
\text { seviyesi }\end{array}$ & $\operatorname{Exp}(B)$ \\
\hline Başak sayısı (adet m²) & -0.023 & 0.006 & 14.369 & 1 & $0.000^{* * *}$ & 0.978 \\
\hline Tane sayısı (adet başak $\left.{ }^{-1}\right)$ & -0.304 & 0.136 & 5.007 & 1 & $0.025^{* *}$ & 0.738 \\
\hline Nimf sayıs1 (adet $\mathrm{m}^{-2}$ ) & 0.634 & 0.157 & 16.275 & 1 & $0.000 * * *$ & 1.885 \\
\hline Sabit & 11.336 & 3.776 & 9.015 & 1 & $0.003 * * *$ & 83824.064 \\
\hline Gözlem sayıs1 & \multicolumn{6}{|l|}{115} \\
\hline Log-Likelihoodvalue & \multicolumn{6}{|l|}{42.846} \\
\hline Cox\&Snell R² & \multicolumn{6}{|l|}{0.601} \\
\hline Nagelkerke $\mathrm{R}^{2}$ & \multicolumn{6}{|l|}{0.829} \\
\hline \multicolumn{7}{|l|}{ Doğru sınıflandırma yüzdesi } \\
\hline Emgi oranı $(\%)<5$ & \multicolumn{6}{|l|}{94.7} \\
\hline Emgi oran $1(\%) \geq 5$ & \multicolumn{6}{|l|}{82.5} \\
\hline Toplam doğru sınıflandırma yüzdesi & \multicolumn{6}{|l|}{90.4} \\
\hline HosmerandLemeshow Test & \multicolumn{6}{|c|}{$\mathrm{X}^{2}=2.332 ; \mathrm{df}=8 ; \mathrm{p}=0.969$} \\
\hline
\end{tabular}

*** \%99 önem seviyesinde anlamlılığ 1 belirtmektedir.

** \%95 önem seviyesinde anlamlılı̆̆ 1 belirtmektedir.

* \%90 önem seviyesinde anlamlılı̆̆ belirtmektedir.

Çizelge 14-17'deki verilerle oluşturulan olasılık formülleri (Çizelge 18) yardımıyla hesaplanan; farklı başak ve tane sayılarında kabul edilebilir üst emgi sınırının üzerinde emgi meydana getirecek nimf sayıları EK 1-5'de verilmiştir.

Çizelge 16. Lojistik regresyon analizi verileri ile oluşturulan formüller

\begin{tabular}{|c|c|}
\hline $\begin{array}{c}\text { Kabul } \\
\text { edilebilir } \\
\text { üst emgi } \\
\text { sinırı (\%) }\end{array}$ & Olasılık formülü \\
\hline 3 & 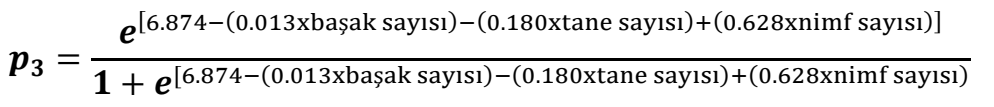 \\
\hline 3.5 & 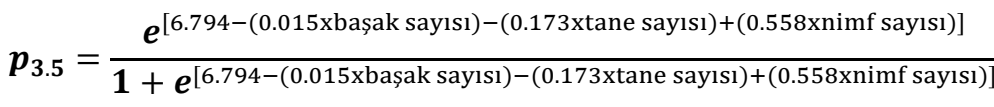 \\
\hline 4 & $\boldsymbol{p}_{\mathbf{4}}=\frac{\boldsymbol{e}^{[8.101-(0.018 \mathrm{xbaşak} \mathrm{sayıs})-(0.187 \mathrm{xtane} \mathrm{sayıs})+(0.549 \mathrm{xnimf} \text { sayıs })]}}{\mathbf{1}+\boldsymbol{e}^{[8.101-(0.018 \text { xbaşak sayısı })-(0.187 \text { xtane sayıs })+(0.549 \mathrm{xnimf} \text { sayısı })]}}$ \\
\hline 5 & $\boldsymbol{p}_{5}=\frac{\boldsymbol{e}^{[11.336-(0.023 \text { xbaşak sayısı })-(0.304 \text { xtane sayısı })+(0.634 \text { xnimf sayısı })]}}{\mathbf{1}+\boldsymbol{e}^{[11.336-(0.023 x b a s ̧ a k ~ s a y ı s ı)-(0.304 \text { xtane sayısı })+(0.634 \text { xnimf sayısı })]}}$ \\
\hline
\end{tabular}

EK 1-5'de görüleceği gibi bitki (başak) sayısının 170-650 adet $\mathrm{m}^{-2}$ ve başaktaki tane sayısının da 17-34 adet arasında değiştiği, kabul edilebilir emgi oranı, $\mathrm{m}^{2}$ 'deki bitki ve başaktaki tane sayısına bağlı olarak zarar oluşturacak nimf sayısının da 1-22 adet $\mathrm{m}^{-2}$ olduğu görülecektir. 
Orta Anadolu Bölgesi’nde buğdayda Avrupa Sünesi (Eurygaster maura L. Hemiptera: Scutelleridae)’nin neden olduğu ürün kayıpları ve ekonomik zarar eşiğinin belirlenmesi

Kafes denemelerinden elde edilen verilerle belirlenen kabul edilebilir üst emgiyi meydana getiren nimf sayılarının tarla koşullarındaki uyum sonuçları incelendiğinde (Çizelge 19); 95 adet tahminden sadece 4 adedinin hatalı olarak tahmin edildiği, yani \%95.79 oranında doğru tahmin yapıldığı görülecektir. Hatalı tahminlerden de sadece 1 adedinde, ilaçlanması gereken tarla ilaçlama dışı bırakılarak zarara neden olunmuştur. Diğer hatalı tahminlerin ise ilaçlanmaması gerek tarlalara ilaçlama kararı alınmış, herhangi bir zarara neden olunmamıştır.

Çizelge 17. Geniş alan çalışma tahmin sonuçları

\begin{tabular}{|c|c|c|c|c|c|c|c|c|}
\hline \multirow{3}{*}{$\begin{array}{c}\text { Başak sayısı } \\
\text { (adet } \mathrm{m}^{-2} \text { ) }\end{array}$} & \multirow{3}{*}{$\begin{array}{c}\text { Tane sayısı } \\
\left(\text { adet başak }^{-1} \text { ) }\right.\end{array}$} & \multirow{3}{*}{$\begin{array}{l}\text { Nimf say1s1 } \\
\left(\text { adet } \mathrm{m}^{-2} \text { ) }\right.\end{array}$} & \multirow{3}{*}{$\begin{array}{c}\text { Emgi } \\
\text { oranı }(\%)\end{array}$} & \multicolumn{5}{|c|}{ Tahmin sonucu } \\
\hline & & & & \multicolumn{5}{|c|}{ Kabul edilebilir üst emgi oranı } \\
\hline & & & & 2 & 3 & 3,5 & 4 & 5 \\
\hline 426.66 & 25.98 & 22.33 & 5.80 & + & + & + & + & + \\
\hline 463.33 & 27.45 & 38.67 & 9.60 & + & + & + & + & + \\
\hline 409.33 & 26.80 & 3.67 & 0.80 & + & + & + & + & + \\
\hline 401.33 & 35.38 & 23.89 & 6.90 & + & + & + & + & + \\
\hline 414.25 & 33.06 & 3.25 & 1.00 & + & + & + & + & + \\
\hline 514.33 & 25.29 & 4.00 & 1.20 & + & + & + & + & + \\
\hline 519.00 & 33.86 & 5.00 & 0.80 & + & + & + & + & + \\
\hline 491.33 & 26.34 & 5.00 & 1.30 & + & + & + & + & + \\
\hline 571.33 & 23.96 & 7.00 & 1.90 & + & + & + & + & + \\
\hline 649.00 & 23.40 & 7.00 & 2.00 & + & + & + & + & + \\
\hline 541.00 & 23.19 & 5.00 & 1.00 & + & + & + & + & + \\
\hline 569.00 & 23.04 & 7.00 & 1.60 & $-{ }^{1}$ & + & + & + & + \\
\hline 532.00 & 26.37 & 14.33 & 3.00 & + & + & -2 & $-^{2}$ & -2 \\
\hline 424.33 & 29.77 & 2.00 & 1.20 & + & + & + & + & + \\
\hline 514.33 & 28.27 & 5.00 & 1.30 & + & + & + & + & + \\
\hline 455.33 & 26.52 & 12.00 & 5.70 & + & + & + & + & + \\
\hline 306.00 & 22.90 & 21.25 & 6.80 & + & + & + & + & + \\
\hline 623.33 & 24.37 & 6.50 & 1.34 & + & + & + & + & + \\
\hline 679.00 & 21.58 & 0.00 & 0.20 & + & + & + & + & + \\
\hline
\end{tabular}

- ${ }^{1}$ İlaçlanması gerekirken ilaçlanmayan alan

${ }_{-2}^{2}$ İlaçlanmaması gerekirken ilaçlanan alan

\section{4. Çimlenmeye Etki}

Çimlendirme ve sürme deneme sonuçları Özkan ve ark. (2014) tarafından yayınlanmıştır. Araştırıcılar, yeni nesil ergin ve nimflerin buğday tanelerinde beslenmesi sonucu ortaya çıkan emgi şiddetinin, diğer bir deyimle zarar görme oranının artması ile birlikte çimlenme hızı, çimlenme gücü, sürme hızı ve sürme gücü değerlerinin azaldığını, tanelerin ağırlığındaki artışa bağlı olarak ta çimlenme ile ilgili tüm parametrelerin aldığı değerlerde artış olduğunu bildirmektedirler. Aynı araştırmacılar emgi şiddetinin artmasına paralel olarak anormal ve ölü tohum sayılarında da artışların olduğunu bildirmektedirler. 


\section{Ekonomik Zarar Eşiğinin Belirlenmesi}

Böcek zararının değerlendirilmesi ve kontrol önlemlerinin başlatılması ilk kez Pierce (1934) tarafından gündeme getirilmiş olup, bugün kullandığımız anlamda ekonomik zarar seviyesi ve ekonomik zarar eşik kavramları Stern et al. (1959) tarafından ortaya atılmıştır. Stern et al. (1959) ekonomik zarar seviyesini "ekonomik kayba neden olabilecek en düşük popülasyon yoğunluğu" olarak ifade etmektedir. Ekonomik zarar eşiği ise "artış eğilimindeki popülasyonun, zarar yapacak düzeye ulaşmadan popülasyonu düşürme girişimlerinin olduğu popülasyon seviyesi" olarak yine aynı araştırmacılar tarafından bildirilmektedir. Böyle popülasyonlar kritik ya da eşik popülasyon olarak adlandırılır. İlaçlama bu eşiği (popülasyonu) aştığında yani, meydana gelecek zararın mücadele masraflarını aşması durumunda önerilmektedir. Ekonomik zarar seviyesinin hesaplanmasında farklı araştırıcılar tarafından değişik yöntemler geliştirilmiş olmakla beraber günümüzde en yaygın olarak Pedigo (1996) tarafından geliştirilmiş aşağıda verilen model kullanılmaktadır. Bu modelde, belirli bir popülasyon yoğunluğunda üründe oluşacak nicel kayıplar ve bu kayıpları önlemek amacıyla harcanan mücadele masrafları arasındaki ilişki açılamaktadır.

$$
\mathrm{EZS}=\mathrm{C} / \mathrm{VxIxDxK}
$$

şeklinde ifade edilen formülde;

$\mathrm{C}=$ Birim alan başına mücadele maliyeti (TL/da)

V=Ürünün pazar değerini (§ $/ \mathrm{kg})$ Ürünün Pazar değeri olarak ürünün beklenen kalitesine bağlı olarak her zaman mümkün olursa ürün için hedeflenen en iyi fiyat değeri kullanılmalıdır (Pedigo 1996)

$\mathrm{I}=$ Her bir böcek tarafından birim alan başına meydana gelen zarar miktarını ( $\%$ yaprak tüketimi/böcek/dekar, oran olarak)

$\mathrm{D}=$ Birim zarar başına kaybı (örn: $\mathrm{kg} / \mathrm{dekar} / \%$ yenilen yaprak)

$\mathrm{K}=$ Zarar veya kayıptaki oransal azalmayı (örn. \%90 için bu katsayı 0.9 olacaktır) ifade etmektedir.

Yukarıda verilen bu tanımlama, verim kaybının (nicelik olarak) kritik faktör olarak değerlendirildiği klasik tanımlamadır. Verime dayalı ekonomik zarar eşikleri zararlının doğrudan üründe beslenmesi sonucu üründe ölçülebilir kayıpların oluşmasına dayanmaktadır. Verim bazlı eşik, zararlı böceklerin büyük bir çoğunluğu için kullanılır. Ancak zarar, verim ve kalite bakımından birlikte ortaya çıkmaktadır. Verim kaybı birim alan başına kütlede bir azalma ( $\mathrm{kg} / \mathrm{ha})$, kalitedeki değişim ise böcek zarar sebebiyle ürünün kalitesinde meydana gelen bozulma şeklinde açıklanmaktadır. Belirli bir kalite eşiği aşıldığında (örn: emgili tane gibi), ürünün değerinde önemli kayıplar meydana geldiğinde yani ürünün fiyatlandırılmasında kalite kritik faktör olarak yer aldığında verim tabanlı eşik yerine kalite tabanlı eşik dikkate alınmalıdır. Kalite tabanlı eşikler verim tabanlı eşiklere göre genellikle çok 
Orta Anadolu Bölgesi’nde buğdayda Avrupa Sünesi (Eurygaster maura L. Hemiptera: Scutelleridae)’nin neden olduğu ürün kayıpları ve ekonomik zarar eşiğinin belirlenmesi

düşük olurlar. Nutter et al. (1993), çoğu meyve ve sebzede olduğu gibi fiyatı belirleyen ana unsurun kalite olması durumunda, zarar eşiğinin sıfıra yakın olduğunu bildirmektedirler. Kalite tabanlı eşiklerde düşük zararlı yoğunluklarında bile önemli zararlar oluşabileceğinden popülasyon yoğunluğunun çok iyi belirlenmesi ve izlenmesi gerekir. Birim alandan elde edilecek ürün yani verim, kalite eşiklerini kullanırken dikkate alınması gereken önemli kriterlerden biridir. Belirli bir böcek yoğunluğunda verimin yüksek olduğu alanda, verimin daha düşük olduğu alana göre zarar oranı da düşük olacaktır.

Sünenin neden olduğu ürün kayıpları ve ekonomik zarar eşiğini belirlemek amacıyla Orta Anadolu Bölgesi doğa koşullarında kafes ve geniş alan denemeleri şeklinde yürütülen bu çalışma sonuçları aşağıda özet olarak verilmektedir.

1. Nicelik yönünden

1.1. Kışlamış erginlerin henüz kardeşlenme döneminde olan buğdayların saplarını emerek sapların kurumaları şeklinde görülen Kurtboğazı zararı buğday kardeşlenme dönemini tamamladığından oluşmamaktadır.

1.2. Kışlamış erginler, başaklar henüz yaprak kılıfı içerisindeyken, çiçek döneminde veya tane bağlarken sapta beslenmeleri nedeniyle başakların kurumaları, beyaz bir renk almaları şeklinde görülen Akbaşak zararı yaklaşık ortalama $\% 0.9$ oranında meydana gelmektedir.

1.3. Nimf ve yeni nesil erginlerin tanede beslenmesi sonucu verimde kayda değer herhangi bir kayıp oluşmamaktadır.

2. Nitelik yönünden

2.1. Nimf ve yeni nesil erginlerin tanede beslenmesi sonucu tanelerin zarar görme oranlarına bağlı olarak çimlenme güçleri yaklaşık \%65 oranında kaybolmaktadır (Özkan ve ark. 2014).

2.2. Nimf ve yeni nesil erginlerin tanede beslenmesi sonucu ekmeklik ve makarnalık özellikleri düşmektedir.

Bu sonuçlardan da anlaşılacağı üzere, Bölgemiz koşullarında süne nedeniyle nitelik yönüyle oluşan kayıpların nicelik yönüyle oluşan kayıplara göre daha yüksek olduğu, yani nitelik yönüyle oluşacak kaybın nicelik yönüyle oluşacak kayba göre çok daha düşük yoğunluktaki popülasyonlarda meydana geleceği, bu nedenle zarar eşiğini tespitte nitelik yönüyle oluşan kayıpların dikkate alınması gerekliliği ortaya çıkmıştır. Stejskal (2001), Hagstrum et al. (1996)'a atfen, depolanmış ürün zararlılarının bulaştıkları ürünlerde beslenmeleri sonucu teknolojik değer, tohumluk kayıpları, gömlek kalıntıları, pislikleri ve salgıladıkları ağ maddeleri nedeniyle meydana getirdikleri nitelik kayıplarının ağırlık kayıplarına göre daha yüksek olduğunu bu sebeple ekonomik zarar eşiği hesaplamalarında her iki zararın da dikkate alınması gerektiğini vurgulamaktadırlar. Aynı şekilde Lahana yaprakbitinin (Brevicoryne brassicae L.) kolzada beslenmesi sonucu verimde meydana gelen 
Özkan M., Babaroğlu N. E., Gökdoğan A., Kan M. ve Koçak E., Bitki Koruma Bülteni, 57 (2), 2017

azalmanın yanında, tanelerin glucosinolate oranını arttırarak kalitesini de düşürmektedir. Bu neden kolzada Lahana yaprakbiti mücadelesinde tespit edilecek ekonomik zarar eşiği hesaplamalarında hem verimdeki hem de tane kalitesinde meydana gelen kayıpların birlikte dikkate alınması gerektiği Ellis et al. (1999) tarafindan bildirilmektedir. Nutter et al. (1993), Cochliobolus sativus'un arpada dekardan elde edilen ürün miktarını azaltması yanında, tanenin protein oranını artırarak (tanenin protein oranı \% 13.5 'in üzerine çıkması durumunda fermantasyon süresi uzamakta, çimlenme süresini ve tekdüzeliğini bozmakta) kalitesini bozduğunu, bu sebeple ekonomik zarar eşiği hesaplamalarında nitel ve nicel kayıpların birlikte dikkate alınması gerektiğini bildirmektedir. Stejskal (2001) üründe her iki tip zararda meydana geliyorsa zararı kantitede oluşan zarar ve kalitede oluşan zarar olamak ikiye ayırmakta buna bağlı olarakta ekonomik zarar eşiği hesaplamalarının yapılması gerektiğini bildirmektedir.

Süne nimf ve yeni nesil erginlerinin tanede beslenmeleri sonucunda oluşan nitelik yönüyle kayıplar incelendiğinde; tanenin ekmeklik ve makarnalık özelliklerinin zarar görme oranı, çimlenme yönüyle meydana gelen zarara göre çok düşük olduğu, bu sebeple, ekonomik zarar eşiğini belirlemede tanenin ekmeklik ve makarnalık özelliklerinin zarar görme oranının temel alınmasının daha doğru olduğu görülecektir. Buğdayın kalite özelliklerinden çimlenme oranının, sertifikasyonda \%85 olmasının yeterli olduğu (Anonim 2011), bu oranın ise ekmeklik ve makarnalık özelliklerinin bozulması için yeterli olan \%2-5 emgi oranından yüksek olduğu görülecektir.

Süne zararı sebebiyle buğdayın fiyatlandırılmasında temel kriter olarak alınan emgili tane oranı sadece zararlı yoğunluğuna göre değil aynı zamanda verime, yani $\mathrm{m}^{2}$ 'deki başak ve başaktaki tane sayısına göre değişiklik göstermesi, ayrıca alıcıların süne zararına uğramış tane oranına göre buğday fiyatlarında yapacağı indirimlerinde yıllara göre değişiklik göstermesi sebebiyle birim alanda belirli bir böcek yoğunluğunun verilmesi doğru olmayacağından, emgili tane oranını etkileyen tüm faktörlerin Bölgemiz koşullarındaki varyasyonları dikkate alınarak EK 1-5’te sunulan çizelgeler hazırlanmıştır.

Bugüne kadar yapılan çalışmalar incelendiğinde ekonomik zarar eşiğinin, zararlının biyolojik dönemlerine, buğdayın çeşit, kullanma amacı (tohumluk, ekmeklik), fenolojik dönemine, iklim koşullarına ve verime göre farklılık gösterdiği görülecektir.

Yüksel (1968), Güneydoğu Anadolu Bölgesi'nde ilkbaharda m²'de 2 adet KE tespit edilmesi durumunda; bunlardan meydana gelecek nimflere karşı mücadele yapılması gerektiğini bildirmektedir.

Lazarov et al. (1969), $\mathrm{m}^{2}$ 'de 2 adet KE olmas1 durumunda ve bunlardan meydana gelen bireylerin meydana getireceği zararın önemli olduğunu vurgulamaktadır. Araştırmacılar 4.5 dönem nimf + YNE dönemlerinde zararın ciddi boyutlara 
Orta Anadolu Bölgesi’nde buğdayda Avrupa Sünesi (Eurygaster maura L. Hemiptera: Scutelleridae)’nin neden olduğu ürün kayıpları ve ekonomik zarar eşiğinin belirlenmesi

ulaştığını da belirterek bu durumda $\mathrm{m}^{2}$ 'de 2 ve daha fazla 4.5 dönem nimf+YNE saptanması durumunda kimyasal mücadele yapılmasını önermektedir.

Tanskii (1973), Rusya'da yaptığı çalışmalar sonucunda ekmeklik buğdaylarda eşiğin kurak yıllarda 0.5 adet $\mathrm{m}^{-2}$, yağışlı yıllarda 1.5 adet $\mathrm{m}^{-2}$ kışlamış ergin, makarnalık buğdaylarda ise kurak yıllarda 0.3 adet $\mathrm{m}^{-2}$, yağışlı yıllarda 1 adet $\mathrm{m}^{-2}$ kışlamış ergin olarak uygulanması gerektiğini bildirmektedir.

Pavlo (1975), Rusya'da yaptı̆̆ çalışmada, buğdayda $\mathrm{m}^{2}$ 'de bitki sayısının 600-700 adet olması durumunda; nimf sürveyleri sonucunda $\mathrm{m}^{2}$ 'de 20 adet üzerinde nimf tespit edilirse kimyasal mücadele yapılması önerilmektedir.

Starostin and Galkine (1976), yaptıkları çalışmaların sonucunda, süne (E. integriceps) için uygulanması gereken ekonomik zarar eşiği değerlerini, 3. dönem nimf 10 adet $\mathrm{m}^{-2}$ ve 1.-2. dönemde ise 15 adet $\mathrm{m}^{-2}$ olarak belirlemişlerdir.

Mustatea (1976), Romanya'da 1969-1974 yılları arasında tahıllarda Eurygaster ve Aelia türleri üzerinde yaptığı çalışmalar sonucunda $\mathrm{m}^{2}$ 'de 10 adet ve üzerinde nimf tespit edilirse kimyasal mücadelenin uygulanmasının gerekli olduğunu belirtmektedir.

Areshnikov (1979), 1972-1973 yılları arasında yaptığı çalışmada kimyasal mücadelede kullanılacak EZE'nin buğdayın çiçeklenme döneminde 10 adet $\mathrm{m}^{-2}$ ve üzeri, süt olum döneminde ise 2-5 adet $\mathrm{m}^{-2}$ nimf olarak dikkate alınması gerektiğini belirtmektedir.

Tilmenbaev et al. (1981), Kazakistan'da yaptıkları çalışma sonucunda; $\mathrm{m}^{2}$ ' de 10 adet ve daha fazla 2. dönem nimf saptanması durumunda kimyasal mücadele yapılmasının gerekli olduğunu vurgulamaktadırlar.

Stavraki (1982), Yunanistan'da yaptığ çalı̧̧ma sonucunda ise; $\mathrm{m}^{2}$ 'de 10 adet ve üzerinde nimf bulunan alanlarda 3. dönem nimflere karşı mücadele yapılma zorunluluğu olduğunu belirtmektedir.

Areshnikov (1984), Ukrayna'da E. integriceps ile yaptığı çalışma sonucunda; EZE değeri olarak $\mathrm{m}^{2}$ 'de 10 ve üzerinde nimf yoğunluğunun dikkate alınması gerektiğini vurgulamaktadır.

Areshnikov and Starostin (1986), tahıllardaki zararlı pentatomidlerle kimyasal mücadele yapmak amaciyla, somut örneklerden yararlanarak Rusya'da yaptığ 1 çalışmalar sonucunda; çiçeklenme ve tane oluşumunun başlangıcında $\mathrm{m}^{2}$ ' $\mathrm{de} 10-15$ nimf, tane oluşum sonu-sarı olum başında ise kaliteli yüksek verim için $\mathrm{m}^{2}$ 'de 2 , tohumluk için de 4-6 adet nimf bulunması durumunda kimyasal mücadele yapılmasını önermektedir.

Areshnikov et al. (1987), Ukrayna'da süne (E. integriceps) mücadelesinde kışlamış erginlere karşı yapılan kimyasal mücadelenin tek başına yeterli olmadığını, ekonomik zarar eşiğini geçtiği takdirde çiçeklenme ve tane oluşumu başlangıcında mutlaka genç nimflere karşı mücadele yapılması gerektiğini bildirmektedir. Daha 
ileri yaştaki nimflerin tane oluşum dönemi sonu-tam oluşum dönemlerindeki hububatın tanelerinde beslenmesi sonucu gluten kalitesini düşürerek hububatın kalitesini etkilediğini belirterek ekonomik zarar eşiğinin istenilen ürünün kalitesine göre değiştiğini $\mathrm{m}^{2}$ 'de 4-6 adet nimf olduğunda mücadele yapılmas1 gerektiğini yüksek kalitede ürün istenildiğinde zararlı sayısının $1-2$ adet $\mathrm{m}^{-2}$ ye düşürülmesi gerektiğini bildirmektedir.

Sheikh and Rahbi (1996), Suriye'de süne (E. integriceps) mücadelesinde EZE değeri olarak; çiçeklenme döneminden tane oluşumuna kadar 5-10 adet $\mathrm{m}^{-2}$ ve süt olum dönemiyle ileriki dönemlerde 5-6 adet $\mathrm{m}^{-2}$ nimf değerlerinin kullanılması gerektiğini bildirmektedir.

Kılıç (1988), Türkiye'de süne mücadelesinin genel olarak 1.-3. dönem nimflere karş1 uygulandığını ve $\mathrm{m}^{2}$ 'de 0.8 adet $\mathrm{KE}$ ve üzerindeki yoğunlukların bulunduğu alanların nimf mücadele programına alınması gerektiğini belirtmekte ve 1.-3. dönem nimflere karşı mücadele bitirilemediği durumlarda $\mathrm{m}^{2}$ 'de 10 adet ve üzerinde nimf + YNE yoğunluğu bulunan tarlalarda kimyasal mücadele yapilmasının gerektiğini de vurgulamaktadır.

Popov (1998), Romanya'da yaptığı çalışmalar sonucunda kimyasal mücadelede uygulanan EZE değerlerinin ürünün vegetatif durumuna, iklim koşullarına, zararlı yoğunluğuna ve ürünün kullanılma amacına göre değişkenlik göstereceğini vurgulamaktadır. EZE değeri olarak ekmeklik buğday yetiştirilen bölgelerde $\mathrm{m}^{2}$ 'de ortalama 5 nimf (3.-4. dönem) ve tohumluk yetiştirilen bölgelerde ise ortalama 3 nimf (3.-4. dönem) değerlerinin uygulanması gerektiğini önermektedir.

Şimşek (1998), Türkiye’de süne mücadelesinin esas olarak 1.-3. dönem nimflere karşı uygulandığını mücadelenin tamamlanamaması durumunda 4.-5. dönemde nimf mücadelesinin yapılması gerektiğini vurgulayarak; nimf sürveyleri sonucunda mücadele eşiği (10 adet $\mathrm{m}^{-2}$ nimf) ve üzerinde belirlenen alanlarda kimyasal mücadele yapılması gerektiğini belirtmektedir.

Bahrami et al. (2003) Kermanşah-İran kuru tarımın yapıldığı buğday alanlarında ekonomik zarar eşiğini belirlemek amacıyla 1996-98 yıllarında buğday tarlalarında çalışmalarını yürütmüş, ekonomik zarar eşiğini buğdayın fizyolojik olum dönemine kadar 4 adet $\mathrm{m}^{-2}$ hasat zamanına kadar da 2.8 adet $\mathrm{m}^{-2}$ nimf oldugunu bildirmektedir.

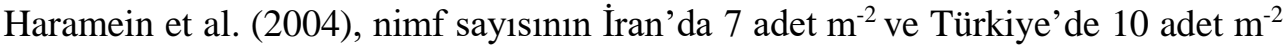
altındaki tarlalardan alınan buğday örneklerinin glüten değerleri ile sağlam tanelerin glüten değerleri karşılaştırıldığında bir farklılığın olmadığını ortaya koymuşlardır. Araştırıcılar bu durumun EZE'lerinin belirlenmesinde dikkate alınması gerektiğini de vurgulamışlardır.

Canhilal ve ark. (2007), Güney ve Güneydoğu bölgesinde yaptığı çalışmalar sonucunda süne (E. integriceps) için EZE değerinin; ekmeklik buğday çeşitleri için 8.1 adet $\mathrm{m}^{-2}$, makarnalık buğday çeşitleri için ise $9.2 \operatorname{adet~}^{-2} \mathrm{nimf}$ olması gerektiğgini bildirmektedirler. 
Orta Anadolu Bölgesi’nde buğdayda Avrupa Sünesi (Eurygaster maura L. Hemiptera: Scutelleridae)’nin neden olduğu ürün kayıpları ve ekonomik zarar eşiğinin belirlenmesi

Popov et al. (2007), Romanya'da süne mücadelesinde uygulanan ekonomik zarar eşiğinin koşullara göre değiştiğini belirterek kışlamış ergin mücadelesinde; bitki siklığının ve gelişimini normal, ilkbaharı yağışlı ve soğuk geçen yıllarda $\mathrm{m}^{2}$ de 7 adet, ilkbaharda yüksek sıcaklıkların olduğu yıllarda 5 adet, bitki sıklığının az, kötü kışlama koşullarında, yağışlı ve 1lık ilkbaharın olduğu yıllarda 3 adet, bitki gelişimi için uygun olmayan (sonbahar-kışın geç bitki çıkışı, kalıcı kar tabakasının olduğu uzun süren kış ile geç ilkbaharın aşırı kurak) yıllarda 1-2 adet kışlamış erginin ekonomik zarar eşiği olarak uygulandığını bildirmektedir. Nimflere (3. dönem) karşı yapılacak mücadelede ise $\mathrm{m}^{2}$ de 5 adet, tohumluk üretiminde ise 3 adet nimfin ekonomik zarar eşiği olarak uygulandığını belirtmektedir.

Kabul edilebilir emgili tane oranının \%3.5 olarak alındığında ekonomik zarar eşiğinin Ege, Akdeniz ve Trakya Bölgeleri için 10 adet $\mathrm{m}^{-2}$ nimf olarak alınmasının uygun olduğu farklı araştırmacılar tarafindan bildirilmektedir (Kaya ve ark. 2009, Akın ve ark. 2009, Güllü ve Kanat 2010, Mutlu ve ark. 2010)

Salis et al. (2013), İtalya'da (Sardinia) baskın türün Eurygaster austriaca olduğunu, zararlı yoğunluğunun bölgeden bölgeye değiştiğini, genellikle düşük yoğunlukta (1.1 adet $\mathrm{m}^{-2}$ ) olmakla beraber bazı alanlarda ekonomik zarar eşiği olan 4 adet $\mathrm{m}^{-}$ 2'nin üzerine çıktığını bildirmektedirler.

Mutlu et al. (2014), Güneydoğu Anadolu Bölgesi'ne özgün ekonomik zarar eşiği, $\mathrm{m}^{2}$ 'de ortalama 350-460 bitki, 26 adet tane ve kabul edilebilir \%3.5 emgi oranında $\mathrm{m}^{2}$ 'de $8,10,12$ aralığında belirlendiğini bildirmektedir.

Kostyukovsky et al. (2014), süneye karşı yapılacak kimyasal mücadelede geçici eşik olarak kışlamış erginlerde 1-2 adet $\mathrm{m}^{-2}$, nimflerde (3.-5. dönem) ise 2-4 adet $\mathrm{m}^{-2}$ olduğunu bildirmektedir.

Çalışma sonuçlarından anlaşılacağı üzere kışlamış erginlere karşı yapılacak kimyasal mücadele uygulamalarında 2-7 adet $\mathrm{m}^{-2}$ ergin, nimflere karşı yapılacak uygulamalarda ise çoğunlukla 10 adet $\mathrm{m}^{-2} \mathrm{nimf}$ olmakla beraber 3-20 adet $\mathrm{m}^{-2} \mathrm{nimf}$ arasında ekonomik zarar eşiği olarak alınmaktadır.

Orta Anadolu Bölgesi'nde süne mücadelesinde uygulanacak ekonomik zarar eşiğini belirlemek amacıyla doğa koşullarında yaptığımız çalışmalar sonucunda; kışlamış erginlerin oluşturduğu kurtboğazı zararının görülmediği, akbaşak zararının ise mücadeleye gerek duyulmayacak oranda (0.09) olduğu tespit edilmiştir. Nimf ve yeni nesil erginlerin tanede beslenmesi nedeniyle kalite yönüyle oluşan kayıpların kantite yönüyle oluşan kayıplara göre çok daha düşük popülasyon yoğunluklarında meydana geldiği ortaya konulmuştur. Aynı şekilde tanenin kalite özelliklerinden ekmeklik ve makarnalık özellikleri bir diğer kalite özelliği olan çimlenme oranına göre çok daha düşük zararlı yoğunluklarında ortaya çıktığından ekonomik zarar eşiği belirlemede tanenin ekmeklik ve makarnalık özelliklerinin zarar görme oranı temel alınmıştır. 
Özkan M., Babaroğlu N. E., Gökdoğan A., Kan M. ve Koçak E., Bitki Koruma Bülteni, 57 (2), 2017

Tanenin ekmeklik ve makarnalık özellikleri çeşitlere göre farklılık göstermekle beraber emgi oranının \%2-8'i geçtiğinde ortaya çıktığı farklı araştırıcıların yaptığ 1 çalışmalarla ortaya konulmuştur. Ekonomik zarar eşiği belirleme amaciyla yaptığımız bu çalışmada kabul edilebilir üst emgi oranı olarak kamu otoritesi tarafindan belirlenen $\% 3.5$ emgi oranı ile birlikte $\% 2,3,4$ ve 5 emgi oranları da dikkate alınarak çizelgeler (EK 1-5) hazırlanmıştır.

Süne zararı sebebiyle buğdayın fiyatlandırılmasında temel kriter olarak alınan emgili tane oranı sadece zararlı yoğunluğuna göre değil aynı zamanda verime, yani $\mathrm{m}^{2}$ 'deki başak ve başaktaki tane sayısına göre değişlik göstermesi, ayrıca alıcıların süne zararına uğramış tane oranına göre buğday fiyatlarında yapacağı indirimlerinde y1llara göre değişiklik göstermesi sebebiyle birim alanda belirli bir böcek yoğunluğunun verilmesi doğru olmayacağından, emgili tane oranını etkileyen tüm faktörlerin Bölgemiz koşullarındaki varyasyonları dikkate alınarak her yıl koşulları kendi içerisinde değerlendirilerek o yıla özgü kararın verilmesinin daha doğru olacağı kanısındayız. Ancak İç Anadolu Bölgesi uzun yıllar ortalama iklim koşullarında, başak sayısının ortalama 407 adet $\mathrm{m}^{-2}$, başaktaki tane sayısının da 26

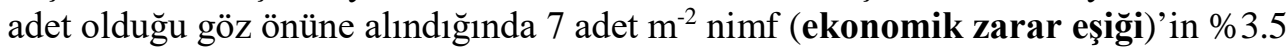
ve üzerinde emgi oluşturacağ 1 ortaya konulmuştur. Buğday ekim alanlarında yapılacak süne nimf sürveyi sonucu $\mathrm{m}^{2}$ 'de 7 adet ve üzerinde nimf tespit edilen alanlarda söz konusu zararlı ile kimyasal mücadele yapılmasının uygun olacağı, süne mücadele zamanına kadar buğday verimini olumsuz yönde etkileyen kuraklık ve benzeri şartların yaşanması durumunda eşik değerinin o yıl için skalalara göre revize edilmesinin uygun olacağı kanısına varılmıştır.

\section{TEŞEKKÜR}

$\mathrm{Bu}$ çalışmanın yürütülmesi aşamasında büyük desteklerini gördüğümüz Tarım İşletmesi Genel Müdürlüğüne teşekkürlerimizi sunarız.

Çalışmanın yürütücüleri arasında bulunan Sn. Atilla GÖKDOĞAN'ın ebediyete intikali nedeniyle, kendini bir kez daha rahmet ve saygıyla anıyoruz. 
Orta Anadolu Bölgesi’nde buğdayda Avrupa Sünesi (Eurygaster maura L. Hemiptera: Scutelleridae)’nin neden olduğu ürün kayıpları ve ekonomik zarar eşiğinin belirlenmesi

\section{KAYNAKLAR}

Aden A. H., Mazid A., Gül A., Majid H.M. and Bouhssini M. 2004. Analysis of Policies on Integrated Pest Management on Sunn pest in Iran, Syria and Turkey. Second International Conference of Sunn Pest, ICARDA, Aleppo, Syria, July 19-22, 2004. 74 p. .

Adıgüzel N. 1981. Fluctuations in Sunn-pest Populations in South-Eastern Anatolia. EPPO Bull., 11(2):19-22.

Agrios N. G. 2005. Plant Pathology (Fifth Edition). Department of Plant Pathology University of Florida.

Akın K., Tülek A., Hekimhan H. ve Kahraman T. 2009. Trakya Bölgesi’nde Süne (Eurygaster spp., Heteroptera: Scutelleridae)'nin Neden Olduğu Ürün Kayıpları ve Ekonomik Zarar Eşiği Üzerinde Araştırmalar. Edirne TTAE. TAGEM. BS-04/01-05164 (5) ve DPT-2004 K 120160 No’lu proje sonuç raporu, 18 s.

Altınayar G. 1981. Orta Anadolu Bölgesi Tahıl Tarlalarındaki Böcek Faunasının Saptanması Üzerinde Çalışmalar. Bitki Koruma Bülteni, 21(2):53-88.

Anonim 2006. Süne Mücadelesi İzleme ve Yönlendirme Komisyonu Toplantı Kararları. 26.12.2006, Ankara.

Anonim 2011. Tahıl Tohumu Sertifikasyonu ve Pazarlaması Yönetmeliğinde Değişiklik Yapılmasına Dair Yönetmelik. 21.02.2011 tarih ve 27853 sayılı Resmi gazete, http//www.resmigazete.gov.tr (erişim tarihi 22.07.2016)

Anonim 2016. Y1llara göre nüfus istatistikleri. http//www.tuik.gov.tr. (erişim tarihi: 3.7.2016).

Anonymous 2004. International Rules for Seed Testing. Edition 2004. Chapter 5. 150 pp.

Anonymous 2014. http//www.fao.org/statistics (erişim tarihi: 25.5.2016)

Areshnikov B. A. 1979. Strategy and Tactics of Protection of Winter Wheat From The Pentatomid. Journal Zashchita Rastenii, 2: 29-30.

Areshnikov B. A. 1984. Problems of Controlling The Sunn Pest in Ukranie. Zashchita Rastenii, 7: 6-9 (Abstr in: Rev. Appl. Ent., 72(12): 7770).

Areshnikov B. A. and Starostin S.P. 1986. Taking Account of Economic Thresholds. Zashchita Rastenii, 2:14-16.

Areshnikov B. A., Kostyukiovski M.G. and Feshchin D.M. 1987. How to Optimize Control of The Sunn Pest. Zashchita Rastenii-Moskva, 5: 22-25.

Argun Ş. M. ve Elgün A. 2015. Süne-Kımıl Zararına Uğramış Buğday Unlarının Ekmekçilik Kalitesinin Tahmininde Kullanılan Uzatmalı Zeleny Sedimantasyon Testinin Optimizasyonu ve Diğer Kalite Parametreleri ile Karşılaştırılması Üzerine Bir Araştırma. GIDA, 40(1), 23-30.

Atlı A. 1987. Trakya Bölgesi Buğdaylarında Görülen Süne Emgi Şikayeti Üzerine Toplanan Numunelerde Yapılan Kalite Çalışmaları Raporu.1. Teknik Rapor,19 s. 
Atlı A., Koçak N., Köksel H., Ozan A. N., Aktan B., Karababa E., Dağ A., Tuncer T., Dimen B. ve Özkan Ş. 1988. Süne (Eurygaster spp.) ve Kımıl (Aelia spp.) Zararı Görmüş Tanelerin Ekmeklik Buğday Kalitesine Etkileri. Tarla Bitkileri Merkez Araştırma Enstitüsü Yayınları, Genel Yayın No: 1988/2, TARM Matbaası, Ankara, 23 s.

Atlı A., Aktan B., Şanal T., Kaplan Evlice A., Ünsal S., Dönmez E., Köten M., Pehlivan A. ve Özderen T. 2010. Makarnalık Buğdayın Kalite Özellikleri ve Kalite Değerlendirme. Makarnalık Buğday ve Mamulleri Konferansı, 7-18 Mayıs 2010, 91109, Şanlıurfa.

Babaroglu N.E., Özkan M. ve Gökdoğan A. 2013. Orta Anadolu Bölgesi Süne (Eurygaster spp.) Mücadele sStratejindeki Değişikliklerin Emgi Oranlarına Etkisi. I. Bitki Koruma Ürünleri ve Makineleri Kongresi Bildirileri, 2-5 Nisan 2013, Antalya, 3:253-264.

Bahrami N., Radjabi G.H., Rezabeygi M. and Kamalı K. 2003. Study on Economic Injury Level of Sunn Pest (Eurygaster integriceps Put.) on Wheat in Rainfed Regions of Kermanshah Province. Applied Entomology and Phytopathology. 70(2):29-45.

Barbulescu A.L. 1973. Observations on The Attack Induced in Wheat by The Overwintering Adults of Eurygaster sp. Analele Institutulu1 De Cercetarı Fundulea. Vol XXXIX. Seri AC. 43-50 p.

Bhatt G.M. 1972. Significance of Path Coefficient Analysis In Determining The Nature of Character Association. Euphytica, 22:338-343.

Bilgic H., Hakki E.E., Pandey A., Khan M.K., Akkaya M.S. 2016. Ancient DNA from 8400 Year Old Çatalhöyük Wheat: Implications For The Origin of Neolithic Agriculture. PLOS ONE 11(3): e0151974.

Blandino M., Marinaccio F., Ingegno B.L., Pansa M.G., Vaccino P., Tavelle L. and Reyneri A. 2015. Evaluation of Common and Durum Wheat Rheological Quality Through Mixolab Analysis After Field Damage By Cereal Bugs. Field Crops Research, 179: 95-102.

Briggle L.W. 1980. Origin and Botany of Wheat. In: Häfliger E. (ed.). Wheat Documenta Cibageigy, p. 6-13. Basle, Switzerland.

Brown E. S., and Eralp M. 1962. The Distribution of the Species of Eurygaster Lap. (Hemiptera, Scutelleridae) in Middle East Countries. Ann. Mag. Nat. Hist., 13(5):6581.

Budak T. 1976. Diyarbakır ve Çevresinde Süne Türlerinin Tespiti, Sünenin (Eurygaster Sp.) Yerli ve Yabancı Orijinli Bazı Buğdayların Değişik Fenolojik Devrelerindeki Zarar Durumu Üzerinde Araştırmalar. Diyarbakır Üniversitesi Tıp Fakültesi Dergisi, 4(4):639-656.

Canhilal R., Kütük H., Kanat A. D., İslamoğlu M., Haramein J.F. and Bouhssini. M. 2005. Economic Threshold for the Sunnpest (Eurygaster integriceps Put) (Hem: Scutelleridae) on Wheat in Southeastern Turkey. J. Agric. Urban Entomol., 22(34):191-204.

Canhilal R., Kutuk H., Islamoglu M., Kanat A. and Gul, A. 2007. Damage Loss Assessment of Sunn Pest on Wheat in Turkey. Arab Society for Plant Protection. 1:187-190. 
Orta Anadolu Bölgesi'nde buğdayda Avrupa Sünesi (Eurygaster maura L. Hemiptera: Scutelleridae)'nin neden olduğu ürün kayıpları ve ekonomik zarar eşiğinin belirlenmesi

Cordain L. 1999. Cereal Grains: Humanity's Double-Edged Sword. In: Simopoulos A.P., Editor. Evolutionary Aspects of Nutrition and Health. Diet, Exercise, Genetics and Chronic Disease. World Rev. Nutr. Diet, vol. 84. Basel: Karger, 19-73 p.

Demir İ. ve Tosun M. 1991. Ekmeklik ve Makarnalık Buğdaylarda Verim ve Bazı Verim Komponentlerinin Korelasyonu ve Path Analizi. Ege Üniversitesi, Ziraat Fakültesi Dergisi, 28(1):41-47.

Dizlek H. ve İslamoğlu M. 2010. Buğday Kitlesindeki Süne Emgi Oranının Belirlenmesinde Ülkemizde Kullanılan Yöntemlerin Karşılaştırılması. Uludağ Üniversitesi Ziraat Fakültesi Dergisi, 24(1), 81-90.

Dizlek H. and Özer M.S. 2016. Effects of Sunn Pest (Eurygaster integriceps) Damage Ratio on Physical, Chemical, and Technological Characteristics of Wheat. Quality Assurance and Safety Of Crops and Foods, 8(1),145-156.

Dörtbudak Y. ve Koyuncu N. 1979. Orta Anadolu'da Süne (Eurygaster spp.) türleri ve yoğunlukları üzerinde ön çalışmalar. Zirai Mücadele Araştırma Y1llı̆̆ı, 2-3.

Dörtbudak Y. Memişoğlu H. Özkan M. Melan K. Kılıç A. U. 1991. Orta Anadolu Bölgesinde (Aelia rostrata Boh.)'in popülasyon yoğunluğunu etkileyen faktörle, neden olduğu ürün kayıpları ve kimyasal mücadelesi üzerinde araştırmalar. Proje KKGA-B-U3,U/A Nihai Raporu 93s.

El-Haramain F.J., Williams P. and Rashawani A. 1984. A Simple Test For The Degree of Damaged Caused in Wheat By Suni Bug (Eurygasterspp.) Infestation. Rachis, 3:1117.

Ellis S.A., Oakley J.N., Parker W.A. and Raw K. 1999. The Development of an Action Threshold for Cabbage Aphid (Brevicoryne brassicae) in Oil Seed Rape in UK. Ann. Appl. Biol., 134: 153-162.

Emel'yanov N. A. 1982. Effect of Differences in Amount of Grain Damage by Eurygaster integriceps on the Baking Quality of Winter Wheats. Doklady Vsesoyuznoî Ordena Leninai Ordena Trudovogo Krasnogo Znameni Akademii Sel'skokhozyaǐstvennykh NaukImeni V. I. Lenina.11:9-11.

Fonseca S. and Patterson F.L. 1968. Yield Component Heritabilities and Interrelationships of Grain Winter Wheat (Triticum austivum L.). CropScience, 8:614-617.

Gebeyehou G., Knott D.R. and Baker R.J. 1982. Relationships Among Durations of Vegetative and Grain Filling Phases, Yield Components, and Grain Yield in Durum Wheat Cultivars. CropScience, 22:287-290.

Gospodinov G.T. and Atanasova I. 1975. Investigations on the Technological Qualities of Wheat Damaged by Sunn pests. Rasteniv'dni-Nauki, 1975, 12:5, 109-117.

Gotsova, V. and Kontev K.H. 1981. Effect of Damage by Eurygaster integriceps on the Baking Quality of Flour of Recommended Wheat Varieties. Rasteniev"dniNauki, 18(4), 33-43.

Güllü M. ve Kanat A. D. 2010. Güney Anadolu Bölgesinde Süne (Eurygaster spp., Heteroptera: Scutelleridae)'nin Neden Olduğu Ürün Kayıları ve Ekonomik Zarar 
Eşiği Üzerinde Araştırmalar. Adana ZMAE TAGEM. BS-04/01-05-164(2) ve DPT2004 K 120160 No’lu proje sonuç raporu, 35s.

Haramein J.F., Bouhssini M., Mafi M. A., Canhilal R. and Kütük H. 2004. The Impact of Sunn pest Density in Wheat Fields on Grain and Flour Quality. Second International Conference of Sunn pest, ICARDA, Aleppo, Syria, July 19-22 2004. 74 p.

Heun M., Schafer-Pregl R., Klawan D., Castagna R., Accerbi M., Borghi B. and Salamini F. 1997. Site of Einkorn Wheat Domestication Identified by DNA Fingerprinting. Science, 278: 1312-14.

Josephides C. M. 1994. Infestation of Cyprus Durum Wheat by Suni Bug and Its Effect Physical Dough Properties. Technical-Bulletin Agricultural Research Institute, No:156: 8 p.

Karababa E. and Ozan A.N. 1998. Effect of Wheat Bug (Eurygaster integriceps) Damage on Quality of a Wheat Variety Grown in Turkey. Journal of the Science of Food and Agriculture, 77:399-403.

Karkodi F. 2004. Investigation on Damage of Overwintered Sunn pest (Eurygaster integriceps Put.) and Their Nymphs in Rainfed Wheat Fields of Kermanshah Province, Iran. Second International Conference of Sunnpest, ICARDA, Aleppo, Syria, July 19-22, 2004. 74 p.

Kaya E., Yılmaz E., Caner Ö. K. 2009. Ege Bölgesinde Süne (Eurygaster spp. , Heteroptera: Scutelleridae)'nin Neden Olduğu Ürün Kayıpları ve Ekonomik Zarar Eşiği Üzerinde Araştırmalar. Bornova ZMAE. TAGEM BS-04/01-05-164(3) ve DPT-2004 K 120160 No'lu proje sonuç raporu, $37 \mathrm{~s}$.

Kılıç A. U., Çatalpınar A., Adıgüzel N., Dörtbudak Y. ve Çavdaroğlu S. 1973. Güneydoğu Anadolu Bölgesinde Süne (Eurygaster integriceps Put.)' nin yayılışı, biyolojisi, ekolojisi, epidemiolojisi ile daha uygun kimyevi mücadele yöntemlerinin araştırılması. A- 106.602 no'lu proje nihai rapor. $121 \mathrm{~s}$.

Kılıç A.U. 1988. Türkiye'de Süne (Eurygaster integriceps Put ) mücadelesinin esasları. 1. Uluslararası Süne Simpozyumu, 13-17 Haziran, Tekirdağ.

Kırtok Y. ve Çölkesen M. 1985. Çukurova Koşullarında Denemeye Alınan Arpa Çeşitlerinde Önemli Bazı Verim Unsurları Üzerinde Path Katsayısı Analizi. Doğa Bilim Dergisi, 9(1):40-49.

Kıvan M. 1999. Buğdayda Eurygaster integriceps Put. ve Eurygaster austriaca Schrk. (Heteroptera: Scutelleridae) Türlerinin Popülasyon Yoğunluğu ile Meydana Getirdiği Zarar Oranı Arasındaki İlişkiler. Türk. Entomol. Derg., 23(4):269-275.

Koçak E. ve Babaroğlu N. 2005. Orta Anadolu Bölgesi Kışlaklarındaki Eurygaster (Heteroptera: Scutelleridae) Türleri. Türk. Entomol. Derg. 29(4):301-307.

Koçak E., Çetin G. ve Hantaş C. 2007. Güney Marmara İlleri Hububat Alanlarındaki Süne (Eurygaster spp., Heteroptera, Scutelleridae) Türleri ve Mücadele Durumu. Uludağ Üniversitesi, Ziraat Fakültesi Dergisi. 21(1):43-50.

Kostyukovsky M., Trostanetsky A., Menasherov A., Yasinov M., Naftaliyahy G., Zohar U., Kitain D. and Melamed S. 2014. Management of Sunn Pest for Better Wheat Quality 
Orta Anadolu Bölgesi’nde buğdayda Avrupa Sünesi (Eurygaster maura L. Hemiptera: Scutelleridae)’nin neden olduğu ürün kayıpları ve ekonomik zarar eşiğinin belirlenmesi and Stable Profitability. Israel Agriculture International Portal (erişim tarihi 14.04.2016).

Lazarov A., Grigorov S., Popov V., Bogdanov V., Abaciev D., Kontev H., Kayzatov H., Gospodinov H., Fitanov H., Duçevski D. 1969. Bulgaristan'da Buğdaygillerde Zarar Yapan Scutelleridae ve Pentatomidae (Hem) Familyalarına Bağlı Türlerin Biyoekolojisi ve Mücadelesi Üzerine Çalışmalar (Çeviri: Musa ALTAY). 144 s.

Lodos N. 1961. Türkiye, Irak, İran ve Suriye'de Süne (Eurygaster integriceps Put.) problemi üzerinde incelemeler. Ege Üniversitesi Ziraat Fakültesi Yayınları, No:51, $115 \mathrm{~s}$.

Lodos N., Önder F., Pehlivan E., Atalay R., Erkin E., Karsavuran Y., Tezcan S., Aksoy S. 1998. Faunistic Studies on Pentatomoidea (Plataspidae, Acanthosomatidae, Cydnidae, Scutelleridae, Pentatomidae) of Western Black Sea, Central Anatolia and Mediterranean regions of Turkey. Ege Üniversitesi Basımevi, Bornova-İzmir, $75 \mathrm{~s}$

Luo M. C., Yang Z. l., You F. M., Kawahara T., Waines J. G., Dvorak J. 2007. The Structure of Wild and Domesticated Emmer Wheat Populations, Gene Flow Between Them, and the Site of Emmer Domestication. Theoretical and Applied Genetics, 114 (6):947959.

Madenoğlu R. Z. 1929. Süne Böceği Hakkında Rapor. İktisat Vekâleti Mecmuası, Numara 2, Hüsnitabiat Matbaas1. 3-36.

Mangelsdorf P.C. 1966. Genetic Potentials For Increasing Yields of Food Crops and Animals. Proc. Natl. Acad. Sci., 56:370-375.

Memişoğlu H. 1985. Ankara İlinde Süne Türlerinin (Eurygaster spp.) (Hemiptera: Pentatomidae) Yayılışları ve E .maura L.’nin Biyo-Ekolojisi ile Savaş Yöntemleri Üzerinde Araştırmalar. 194 s. (Yayınlanmamış doktora tezi)

Haramein N. A. and Shurovenkov Y.U.B. 1977. Insects and the Quality of Hard Wheat Grain. Zashchita Rastenii, No:7:46

Mustatea D. 1976. The Cereal Bugs (Eurygaster spp. and Aelia spp.) in Romania. The Papers of the 5th Interbalcanic Plant Protection Conference Probleme de Protectia Plantelor, 4:175-184.

Mutlu Ç., Karaca M., Duman M., Gözüaçık C., Şanal T. ve Kan M. 2010. Güneydoğu Anadolu Bölgesinde Süne (Eurygaster integriceps Put)'nin Neden Olduğu Ürün Kayıpları ve Ekonomik Zarar Eşiği Üzerinde Araştırmalar. TAGEM/BS-04/01-05164 (4) nolu proje sonuç raporu.

Mutlu Ç., Canhilal R., Karaca V., Duman M., Gözüaçık C. and Kan M. 2014. Economic Threshold Revision of the Sun Pest (Eurygaster integriceps Put.) (Hemiptera:Scutelleridae) on Wheat in Southeastern Anatolia Region. Türk. Entomol. Bült., 4(3):157-169.

Najafi-Mireak T. 2012. Evaluation of Resistance to Sunn pest (Eurygaster integriceps Put.) in Wheat and Triticale Genotypes. Crop Breeding Journal, 2(1): 43-48

Nutter F.W., Teng P.S. and Matthew H.R. 1993. Terms and Concepts for Yield, Crop Loss, and Disease Threshold. Plant. Dis., 77, 211-215. 
Özkan M., Babaroğlu N. E., Gökdoğan A., Kan M. ve Koçak E., Bitki Koruma Bülteni, 57 (2), 2017

Nuttonson M.Y. 1955. Wheat Climatic Relationships and the Use of Phenology in Ascertaining the Thermal and Photothermal Requirements of Wheat. Washington, DC, American Institute of Crop Ecology.

Nouri H. 2007. Loss Assessment and Economic Levels for Sunn pest in Qazvin Province, Iran. A Decade of Progress, 1994-2004, 349-354 p.

Nouri H. and Shahrokhi S. 2012. Economic Levels for Sunn pest Eurygaster integriceps Put. (Het.: Scutelleridae) on Wheat in Iran. International Journal of Agronomy and Plant Production, 3(11): 483-488.

Özderen T., Olanca B., Sanal T., Ozay D.S. and Koksel H. 2008. Effects of Suni-bug (Eurygaster spp.) Damage on Semolina Properties and Spaghetti Quality Characteristics of Durum Wheats (Triticum durum L.). Journal of Cereal Science, 48:464-470.

Özkan M., Babaroğlu N. E., Gökdoğan A. 2014. Avrupa Sünesi (Eurygaster maura L.)’nin Emgi Zararının Buğdayda Çimlenme ve Sürmeye Etkisi. Bitki Koruma Bülteni, 54(2):191-200.

Özkan M. ve Babaroğlu N. E. 2015. Süne. Gıda ve Kontrol Genel Müdürlüğü Yayınları, Ses Reklam İletişim ve Basım Hizmetleri, Ankara, 208 s.

Pavlo V.I.F. 1975. Agrotechinical Plant Protection Methods. VIII. International Plant Protection Congrees, Moscow, 1975, Vol III. 121-125.

Pedigo L. P. 1996. Entomology and Pest Management. Second Edition. 1996. Prentice-Hall Pub., Englewood Cliffs, NJ. 679 pp.

Petrova I. 2002. Effect of Bug Damage on Cooking Potential of Bulgarian Durum Wheat Cultivars Depending on Their Gluten Strength. Bulg. J. Agric. Sci., 8:245-250.

Pierce W.D. 1934. At What Point Does Insect Attack Become Damage? Entomologi, calnews 45:1-4.

Popov C. 1998. Romanya’da Sünenin Yönetimi. Entegre Süne Mücadelesi, I. Workshop Raporu, 6-9 Ocak Ankara, 165 s, (35-45 s.)

Popov C., Barbulescu A.L., Muresonu F., Vasilescu S., Gogu F. and Dobrin F. 2007. Sunnpest in Romania. SunnPest Management, A Decade of Progress, 1994-2004.

Puri Y.P., Qualset C.O. and Williams W.A. 1982. Evaluation of Yield Components as Selection Criteria in Barley Breeding. Crop Science, 22:927-931.

Salis L., Goula M., Izquierdo J., Gordun E. 2013. Population Density and Distribution of Wheat Bugs Infesting Durum Wheat in Sardinia, Italy. Journal of Insect Science, 13(50):1-15.

Saric M., Psodorov D., Zivancev D. and Kosutic M. 2003. Deviation of Processing Quality of Wheat Caused by Wheat Bug (Eurygaster) Infestation. Flour-Bread '03: Proceedings of International Congress, 4th Croatian Congress of Cereal Technologists, Opatija, Croatia, 19-22 November 2003.

Sheikh K. and Rahbi M. A. 1996. The Syrian Arab Republic. Sunn Pest and Their Control in the Near East. FAO Plan Production and Protection Paper. 165 p. 
Orta Anadolu Bölgesi'nde buğdayda Avrupa Sünesi (Eurygaster maura L. Hemiptera: Scutelleridae)'nin neden olduğu ürün kayıpları ve ekonomik zarar eşiğinin belirlenmesi

Shurovenkov Y. B., Ermakov A. V., Boiko N. I., Mikhailova N. A. and Volodichev M. A. 1984. Grain Condition and the Sunn pest. Zashchita Rastenii, No. 8 pp. 8-9

Sidwell R.J., Smith E.L. and Mc New R.W. 1976. Inheritance and Interrelationships of Grain Yield and Selected Yield-Related Traits in A Hard Red Winter Wheat Cross. Crop Science, 16(5):650-654.

Starostin S.P. and Galkina R. G. 1976. Effects of Dates Control of Nymphs of the Noxius Pentatomid on Its Dynamics of Numbers and Injuriousness the Wheat Grains. Zashchity Rastenii, 45:30-34.

Stavraki H. G. 1982. Study on the Biology and Ecology of Wheat Pests of the Family Pentatomidae in The Central Greece. Annales-de-I'Institut-PhytopathologiqueBenaki, 13(2): 213-232.

Stejskal V. 2001. A New Concept of Economic Injury Level That Include Speciaalization of Damage to Quality and Safety of Agricultural Products. Plant Protect. Sci., 37: 151156.

Stern V.M., Smitth R.R., Van den Bosch R. and Hagen K.S. 1959. The Integrated Control Consept. Hilgardia, 29: 81-101.

Stoskopf N.C. 1985. Cereal Grain Crops. Reston, Reston Publishing Company, 1985.

Şanal T. 2009. Gıda Teknolojileri Araştırmaları. Ülkesel Süne Projesi Sonuç Raporu, 20042009. $217 \mathrm{~s}$.

Şimşek Z. 1998. Türkiye’de Süne (Eurygaster spp.) Mücadelesinin Genel Durumu, Dünü, Bugünü. Entegre Süne Mücadelesi, I. Workshop Raporu, 6-9 Ocak 1998, Ankara, 165 s.

Tanskii V.I. 1973. Studies on Insect Damage and Economic Thresholds in the Soviet Union. OEPP/EPPO Bull. 3(3): 101-104.

Tayakısı İ., Teoman A., Kavgacı A. 1973. Adana İlinde Süne (Eurygaster integriceps Put.) Biyolojisi ile Buğday Fenolojisi Arasında İlgi ve Danede Zarar Derecesinin Tesbiti Üzerinde Ön Çalışmalar. Zirai Mücadele Araştırma Yıllı̆̆ı, Tarım Bakanlığı Zirai Mücadele ve Karantina Genel Müdürlüğü Araştırma Serisi, Sayı 7, Ankara, 2-3 s.

Tilmenbeav A.T., Beksultanov S.T. and Sarboev A.T. 1981. The Main Elements of Integrated Control of the Sunn pest in Kazakhstan. Noveishie-dostizhenyasel'skokhozyaistvennoi-entomologii-po-materialam-Ush-s"'ezda-VEO, Vil'nyus-913-oktyabrya-1979. recd. 1983, 184-186.

Vojdani S. 1961. Bio-ecology of Some Eurygaster species in Central California (Pentatomidae-Scutellerinae). Annals Entomological Society of America, 54(4): 567578.

Wagner E. 1959. Beitragzur Heteropteren Fauna Anatoliens. Z. Ang. Ent., 44(1):102-113.

Yüksel M. 1968. Güney ve Güneydoğu Anadolu'da Süne (Eurygaster integriceps Put.)'nin Yayılışı, Biyolojisi, Ekolojisi, Epidemiolojisi ve Zararı Üzerinde Araştırmalar. T.C. Tarım Bakanlığı, Zirai Müc. ve Kar. Gn. Md. Yayınları, No:46, Teknik Bülten, Yenidesen Matbaası, Ankara, 255 s. 
Özkan M., Babaroğlu N. E., Gökdoğan A., Kan M. ve Koçak E., Bitki Koruma Bülteni, 57 (2), 2017

Yüksel M. 1969. Süne (Eurygaster integriceps Put.) Zararı ve Kımıl (Aelia rostrata Boh.) Zararıyla Mukayesesi Üzerinde Araştırmalar. Diyarbakır Bölge Zirai Mücadele Araş. Ens., Yenidesen Matbaas1, 70 s.

Zwölfer W. 1942. Anadolu Böcek Direyi Üzerine Etüt II. Süne’nin (Eurygaster integriceps Put.) Kendisinin Muhit Hayatı Faktörler Karşı Münasebetleri. (Çeviren Prof. Dr. Mithat Ali Tolunay). T.C. Ziraat Vekaleti Neşriyatı, Sayı: 543, Nebat Hastalıkları serisi:10, 35-66 s. 
Orta Anadolu Bölgesi’nde buğdayda Avrupa Sünesi (Eurygaster maura L. Hemiptera: Scutelleridae)’nin neden olduğu ürün kayıpları ve ekonomik zarar eşiğinin belirlenmesi

\section{EK 1}

Kabul edilebilir üst emgi oranı \%2'ye göre dikkate alınması gereken ekonomik zarar eşiği değerleri

\begin{tabular}{|c|c|c|c|c|c|c|c|c|c|c|c|c|c|c|c|c|c|c|}
\hline \multirow{2}{*}{$\begin{array}{l}\text { Bitki sayısı } \\
{\text { (adet } \mathbf{m}^{-2} \text { ) }}^{\text {ade }}\end{array}$} & \multicolumn{18}{|c|}{ Tane sayısı (adet başak ${ }^{-1}$ ) } \\
\hline & 17 & 18 & 19 & 20 & 21 & 22 & 23 & 24 & 25 & 26 & 27 & 28 & 29 & 30 & 31 & 32 & 33 & 34 \\
\hline 170 & 1 & 1 & 1 & 1 & 1 & 1 & 1 & 1 & 1 & 1 & 1 & 1 & 1 & 1 & 1 & 1 & 1 & 1 \\
\hline 175 & 1 & 1 & 1 & 1 & 1 & 1 & 1 & 1 & 1 & 1 & 1 & 1 & 1 & 1 & 1 & 1 & 1 & 1 \\
\hline 180 & 1 & 1 & 1 & 1 & 1 & 1 & 1 & 1 & 1 & 1 & 1 & 1 & 1 & 1 & 1 & 1 & 1 & 1 \\
\hline 185 & 1 & 1 & 1 & 1 & 1 & 1 & 1 & 1 & 1 & 1 & 1 & 1 & 1 & 1 & 1 & 1 & 1 & 1 \\
\hline 190 & 1 & 1 & 1 & 1 & 1 & 1 & 1 & 1 & 1 & 1 & 1 & 1 & 1 & 1 & 1 & 1 & 1 & 1 \\
\hline 195 & 1 & 1 & 1 & 1 & 1 & 1 & 1 & 1 & 1 & 1 & 1 & 1 & 1 & 1 & 1 & 1 & 1 & 1 \\
\hline 200 & 1 & 1 & 1 & 1 & 1 & 1 & 1 & 1 & 1 & 1 & 1 & 1 & 1 & 1 & 1 & 1 & 1 & 1 \\
\hline 205 & 1 & 1 & 1 & 1 & 1 & 1 & 1 & 1 & 1 & 1 & 1 & 1 & 1 & 1 & 1 & 1 & 1 & 2 \\
\hline 210 & 1 & 1 & 1 & 1 & 1 & 1 & 1 & 1 & 1 & 1 & 1 & 1 & 1 & 1 & 1 & 2 & 2 & 2 \\
\hline 215 & 1 & 1 & 1 & 1 & 1 & 1 & 1 & 1 & 1 & 1 & 1 & 1 & 1 & 1 & 2 & 2 & 2 & 2 \\
\hline 220 & 1 & 1 & 1 & 1 & 1 & 1 & 1 & 1 & 1 & 1 & 1 & 1 & 1 & 2 & 2 & 2 & 2 & 2 \\
\hline 225 & 1 & 1 & 1 & 1 & 1 & 1 & 1 & 1 & 1 & 1 & 1 & 1 & 2 & 2 & 2 & 2 & 2 & 2 \\
\hline 230 & 1 & 1 & 1 & 1 & 1 & 1 & 1 & 1 & 1 & 1 & 2 & 2 & 2 & 2 & 2 & 2 & 2 & 2 \\
\hline 235 & 1 & 1 & 1 & 1 & 1 & 1 & 1 & 1 & 1 & 2 & 2 & 2 & 2 & 2 & 2 & 2 & 2 & 2 \\
\hline 240 & 1 & 1 & 1 & 1 & 1 & 1 & 1 & 1 & 2 & 2 & 2 & 2 & 2 & 2 & 2 & 2 & 2 & 2 \\
\hline 245 & 1 & 1 & 1 & 1 & 1 & 1 & 1 & 2 & 2 & 2 & 2 & 2 & 2 & 2 & 2 & 2 & 2 & 2 \\
\hline 250 & 1 & 1 & 1 & 1 & 1 & 2 & 2 & 2 & 2 & 2 & 2 & 2 & 2 & 2 & 2 & 2 & 2 & 2 \\
\hline 255 & 1 & 1 & 1 & 1 & 2 & 2 & 2 & 2 & 2 & 2 & 2 & 2 & 2 & 2 & 2 & 2 & 2 & 2 \\
\hline 260 & 1 & 1 & 1 & 2 & 2 & 2 & 2 & 2 & 2 & 2 & 2 & 2 & 2 & 2 & 2 & 2 & 2 & 2 \\
\hline 265 & 1 & 1 & 2 & 2 & 2 & 2 & 2 & 2 & 2 & 2 & 2 & 2 & 2 & 2 & 2 & 2 & 2 & 2 \\
\hline 270 & 2 & 2 & 2 & 2 & 2 & 2 & 2 & 2 & 2 & 2 & 2 & 2 & 2 & 2 & 2 & 2 & 2 & 3 \\
\hline 275 & 2 & 2 & 2 & 2 & 2 & 2 & 2 & 2 & 2 & 2 & 2 & 2 & 2 & 2 & 2 & 2 & 3 & 3 \\
\hline 280 & 2 & 2 & 2 & 2 & 2 & 2 & 2 & 2 & 2 & 2 & 2 & 2 & 2 & 2 & 2 & 3 & 3 & 3 \\
\hline 285 & 2 & 2 & 2 & 2 & 2 & 2 & 2 & 2 & 2 & 2 & 2 & 2 & 2 & 3 & 3 & 3 & 3 & 3 \\
\hline 290 & 2 & 2 & 2 & 2 & 2 & 2 & 2 & 2 & 2 & 2 & 2 & 2 & 3 & 3 & 3 & 3 & 3 & 3 \\
\hline 295 & 2 & 2 & 2 & 2 & 2 & 2 & 2 & 2 & 2 & 2 & 2 & 3 & 3 & 3 & 3 & 3 & 3 & 3 \\
\hline 300 & 2 & 2 & 2 & 2 & 2 & 2 & 2 & 2 & 2 & 2 & 3 & 3 & 3 & 3 & 3 & 3 & 3 & 3 \\
\hline 305 & 2 & 2 & 2 & 2 & 2 & 2 & 2 & 2 & 3 & 3 & 3 & 3 & 3 & 3 & 3 & 3 & 3 & 3 \\
\hline 310 & 2 & 2 & 2 & 2 & 2 & 2 & 2 & 3 & 3 & 3 & 3 & 3 & 3 & 3 & 3 & 3 & 3 & 3 \\
\hline 315 & 2 & 2 & 2 & 2 & 2 & 2 & 3 & 3 & 3 & 3 & 3 & 3 & 3 & 3 & 3 & 3 & 3 & 3 \\
\hline 320 & 2 & 2 & 2 & 2 & 2 & 3 & 3 & 3 & 3 & 3 & 3 & 3 & 3 & 3 & 3 & 3 & 3 & 3 \\
\hline 325 & 2 & 2 & 2 & 3 & 3 & 3 & 3 & 3 & 3 & 3 & 3 & 3 & 3 & 3 & 3 & 3 & 3 & 3 \\
\hline 330 & 2 & 2 & 3 & 3 & 3 & 3 & 3 & 3 & 3 & 3 & 3 & 3 & 3 & 3 & 3 & 3 & 3 & 3 \\
\hline 335 & 2 & 3 & 3 & 3 & 3 & 3 & 3 & 3 & 3 & 3 & 3 & 3 & 3 & 3 & 3 & 3 & 3 & 3 \\
\hline 340 & 3 & 3 & 3 & 3 & 3 & 3 & 3 & 3 & 3 & 3 & 3 & 3 & 3 & 3 & 3 & 3 & 3 & 4 \\
\hline 345 & 3 & 3 & 3 & 3 & 3 & 3 & 3 & 3 & 3 & 3 & 3 & 3 & 3 & 3 & 3 & 4 & 4 & 4 \\
\hline 350 & 3 & 3 & 3 & 3 & 3 & 3 & 3 & 3 & 3 & 3 & 3 & 3 & 3 & 3 & 4 & 4 & 4 & 4 \\
\hline 355 & 3 & 3 & 3 & 3 & 3 & 3 & 3 & 3 & 3 & 3 & 3 & 3 & 3 & 4 & 4 & 4 & 4 & 4 \\
\hline 360 & 3 & 3 & 3 & 3 & 3 & 3 & 3 & 3 & 3 & 3 & 3 & 3 & 4 & 4 & 4 & 4 & 4 & 4 \\
\hline 365 & 3 & 3 & 3 & 3 & 3 & 3 & 3 & 3 & 3 & 3 & 4 & 4 & 4 & 4 & 4 & 4 & 4 & 4 \\
\hline 370 & 3 & 3 & 3 & 3 & 3 & 3 & 3 & 3 & 3 & 4 & 4 & 4 & 4 & 4 & 4 & 4 & 4 & 4 \\
\hline 375 & 3 & 3 & 3 & 3 & 3 & 3 & 3 & 3 & 4 & 4 & 4 & 4 & 4 & 4 & 4 & 4 & 4 & 4 \\
\hline 380 & 3 & 3 & 3 & 3 & 3 & 3 & 3 & 4 & 4 & 4 & 4 & 4 & 4 & 4 & 4 & 4 & 4 & 4 \\
\hline 385 & 3 & 3 & 3 & 3 & 3 & 4 & 4 & 4 & 4 & 4 & 4 & 4 & 4 & 4 & 4 & 4 & 4 & 4 \\
\hline 390 & 3 & 3 & 3 & 3 & 4 & 4 & 4 & 4 & 4 & 4 & 4 & 4 & 4 & 4 & 4 & 4 & 4 & 4 \\
\hline 395 & 3 & 3 & 3 & 4 & 4 & 4 & 4 & 4 & 4 & 4 & 4 & 4 & 4 & 4 & 4 & 4 & 4 & 4 \\
\hline 400 & 3 & 3 & 4 & 4 & 4 & 4 & 4 & 4 & 4 & 4 & 4 & 4 & 4 & 4 & 4 & 4 & 4 & 4 \\
\hline 405 & 4 & 4 & 4 & 4 & 4 & 4 & 4 & 4 & 4 & 4 & 4 & 4 & 4 & 4 & 4 & 4 & 4 & 5 \\
\hline 410 & 4 & 4 & 4 & 4 & 4 & 4 & 4 & 4 & 4 & 4 & 4 & 4 & 4 & 4 & 4 & 4 & 5 & 5 \\
\hline
\end{tabular}




\section{EK 1 Devam}

Kabul edilebilir üst emgi oranı \%2'ye göre dikkate alınması gereken ekonomik zarar eşiği değerleri

\begin{tabular}{|c|c|c|c|c|c|c|c|c|c|c|c|c|c|c|c|c|c|c|}
\hline \multirow{2}{*}{ 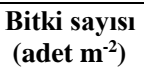 } & \multicolumn{18}{|c|}{ Tane sayısı (adet başak ${ }^{-1)}$} \\
\hline & 17 & 18 & 19 & 20 & 21 & 22 & 23 & 24 & 25 & 26 & 27 & 28 & 29 & 30 & 31 & 32 & 33 & 34 \\
\hline 415 & 4 & 4 & 4 & 4 & 4 & 4 & 4 & 4 & 4 & 4 & 4 & 4 & 4 & 4 & 4 & 5 & 5 & 5 \\
\hline 420 & 4 & 4 & 4 & 4 & 4 & 4 & 4 & 4 & 4 & 4 & 4 & 4 & 4 & 5 & 5 & 5 & 5 & 5 \\
\hline 425 & 4 & 4 & 4 & 4 & 4 & 4 & 4 & 4 & 4 & 4 & 4 & 4 & 5 & 5 & 5 & 5 & 5 & 5 \\
\hline 430 & 4 & 4 & 4 & 4 & 4 & 4 & 4 & 4 & 4 & 4 & 4 & 5 & 5 & 5 & 5 & 5 & 5 & 5 \\
\hline 435 & 4 & 4 & 4 & 4 & 4 & 4 & 4 & 4 & 4 & 4 & 5 & 5 & 5 & 5 & 5 & 5 & 5 & 5 \\
\hline 440 & 4 & 4 & 4 & 4 & 4 & 4 & 4 & 4 & 5 & 5 & 5 & 5 & 5 & 5 & 5 & 5 & 5 & 5 \\
\hline 445 & 4 & 4 & 4 & 4 & 4 & 4 & 4 & 5 & 5 & 5 & 5 & 5 & 5 & 5 & 5 & 5 & 5 & 5 \\
\hline 450 & 4 & 4 & 4 & 4 & 4 & 4 & 5 & 5 & 5 & 5 & 5 & 5 & 5 & 5 & 5 & 5 & 5 & 5 \\
\hline 455 & 4 & 4 & 4 & 4 & 4 & 5 & 5 & 5 & 5 & 5 & 5 & 5 & 5 & 5 & 5 & 5 & 5 & 5 \\
\hline 460 & 4 & 4 & 4 & 5 & 5 & 5 & 5 & 5 & 5 & 5 & 5 & 5 & 5 & 5 & 5 & 5 & 5 & 5 \\
\hline 465 & 4 & 4 & 5 & 5 & 5 & 5 & 5 & 5 & 5 & 5 & 5 & 5 & 5 & 5 & 5 & 5 & 5 & 5 \\
\hline 470 & 4 & 5 & 5 & 5 & 5 & 5 & 5 & 5 & 5 & 5 & 5 & 5 & 5 & 5 & 5 & 5 & 5 & 5 \\
\hline 475 & 5 & 5 & 5 & 5 & 5 & 5 & 5 & 5 & 5 & 5 & 5 & 5 & 5 & 5 & 5 & 5 & 5 & 6 \\
\hline 480 & 5 & 5 & 5 & 5 & 5 & 5 & 5 & 5 & 5 & 5 & 5 & 5 & 5 & 5 & 5 & 6 & 6 & 6 \\
\hline 485 & 5 & 5 & 5 & 5 & 5 & 5 & 5 & 5 & 5 & 5 & 5 & 5 & 5 & 5 & 6 & 6 & 6 & 6 \\
\hline 490 & 5 & 5 & 5 & 5 & 5 & 5 & 5 & 5 & 5 & 5 & 5 & 5 & 5 & 6 & 6 & 6 & 6 & 6 \\
\hline 495 & 5 & 5 & 5 & 5 & 5 & 5 & 5 & 5 & 5 & 5 & 5 & 5 & 6 & 6 & 6 & 6 & 6 & 6 \\
\hline 500 & 5 & 5 & 5 & 5 & 5 & 5 & 5 & 5 & 5 & 5 & 6 & 6 & 6 & 6 & 6 & 6 & 6 & 6 \\
\hline 505 & 5 & 5 & 5 & 5 & 5 & 5 & 5 & 5 & 5 & 6 & 6 & 6 & 6 & 6 & 6 & 6 & 6 & 6 \\
\hline 510 & 5 & 5 & 5 & 5 & 5 & 5 & 5 & 5 & 6 & 6 & 6 & 6 & 6 & 6 & 6 & 6 & 6 & 6 \\
\hline 515 & 5 & 5 & 5 & 5 & 5 & 5 & 5 & 6 & 6 & 6 & 6 & 6 & 6 & 6 & 6 & 6 & 6 & 6 \\
\hline 520 & 5 & 5 & 5 & 5 & 5 & 6 & 6 & 6 & 6 & 6 & 6 & 6 & 6 & 6 & 6 & 6 & 6 & 6 \\
\hline 525 & 5 & 5 & 5 & 5 & 6 & 6 & 6 & 6 & 6 & 6 & 6 & 6 & 6 & 6 & 6 & 6 & 6 & 6 \\
\hline 530 & 5 & 5 & 5 & 6 & 6 & 6 & 6 & 6 & 6 & 6 & 6 & 6 & 6 & 6 & 6 & 6 & 6 & 6 \\
\hline 535 & 5 & 5 & 6 & 6 & 6 & 6 & 6 & 6 & 6 & 6 & 6 & 6 & 6 & 6 & 6 & 6 & 6 & 6 \\
\hline 540 & 6 & 6 & 6 & 6 & 6 & 6 & 6 & 6 & 6 & 6 & 6 & 6 & 6 & 6 & 6 & 6 & 6 & 7 \\
\hline 545 & 6 & 6 & 6 & 6 & 6 & 6 & 6 & 6 & 6 & 6 & 6 & 6 & 6 & 6 & 6 & 6 & 7 & 7 \\
\hline 550 & 6 & 6 & 6 & 6 & 6 & 6 & 6 & 6 & 6 & 6 & 6 & 6 & 6 & 6 & 6 & 7 & 7 & 7 \\
\hline 555 & 6 & 6 & 6 & 6 & 6 & 6 & 6 & 6 & 6 & 6 & 6 & 6 & 6 & 7 & 7 & 7 & 7 & 7 \\
\hline 560 & 6 & 6 & 6 & 6 & 6 & 6 & 6 & 6 & 6 & 6 & 6 & 6 & 7 & 7 & 7 & 7 & 7 & 7 \\
\hline 565 & 6 & 6 & 6 & 6 & 6 & 6 & 6 & 6 & 6 & 6 & 6 & 7 & 7 & 7 & 7 & 7 & 7 & 7 \\
\hline 570 & 6 & 6 & 6 & 6 & 6 & 6 & 6 & 6 & 6 & 6 & 7 & 7 & 7 & 7 & 7 & 7 & 7 & 7 \\
\hline 575 & 6 & 6 & 6 & 6 & 6 & 6 & 6 & 6 & 7 & 7 & 7 & 7 & 7 & 7 & 7 & 7 & 7 & 7 \\
\hline 580 & 6 & 6 & 6 & 6 & 6 & 6 & 6 & 7 & 7 & 7 & 7 & 7 & 7 & 7 & 7 & 7 & 7 & 7 \\
\hline 585 & 6 & 6 & 6 & 6 & 6 & 6 & 7 & 7 & 7 & 7 & 7 & 7 & 7 & 7 & 7 & 7 & 7 & 7 \\
\hline 590 & 6 & 6 & 6 & 6 & 6 & 7 & 7 & 7 & 7 & 7 & 7 & 7 & 7 & 7 & 7 & 7 & 7 & 7 \\
\hline 595 & 6 & 6 & 6 & 7 & 7 & 7 & 7 & 7 & 7 & 7 & 7 & 7 & 7 & 7 & 7 & 7 & 7 & 7 \\
\hline 600 & 6 & 6 & 7 & 7 & 7 & 7 & 7 & 7 & 7 & 7 & 7 & 7 & 7 & 7 & 7 & 7 & 7 & 7 \\
\hline 605 & 6 & 7 & 7 & 7 & 7 & 7 & 7 & 7 & 7 & 7 & 7 & 7 & 7 & 7 & 7 & 7 & 7 & 7 \\
\hline 610 & 7 & 7 & 7 & 7 & 7 & 7 & 7 & 7 & 7 & 7 & 7 & 7 & 7 & 7 & 7 & 7 & 7 & 8 \\
\hline 615 & 7 & 7 & 7 & 7 & 7 & 7 & 7 & 7 & 7 & 7 & 7 & 7 & 7 & 7 & 7 & 8 & 8 & 8 \\
\hline 620 & 7 & 7 & 7 & 7 & 7 & 7 & 7 & 7 & 7 & 7 & 7 & 7 & 7 & 7 & 8 & 8 & 8 & 8 \\
\hline 625 & 7 & 7 & 7 & 7 & 7 & 7 & 7 & 7 & 7 & 7 & 7 & 7 & 7 & 8 & 8 & 8 & 8 & 8 \\
\hline 630 & 7 & 7 & 7 & 7 & 7 & 7 & 7 & 7 & 7 & 7 & 7 & 7 & 8 & 8 & 8 & 8 & 8 & 8 \\
\hline 635 & 7 & 7 & 7 & 7 & 7 & 7 & 7 & 7 & 7 & 7 & 8 & 8 & 8 & 8 & 8 & 8 & 8 & 8 \\
\hline 640 & 7 & 7 & 7 & 7 & 7 & 7 & 7 & 7 & 7 & 8 & 8 & 8 & 8 & 8 & 8 & 8 & 8 & 8 \\
\hline 645 & 7 & 7 & 7 & 7 & 7 & 7 & 7 & 7 & 8 & 8 & 8 & 8 & 8 & 8 & 8 & 8 & 8 & 8 \\
\hline 650 & 7 & 7 & 7 & 7 & 7 & 7 & 7 & 8 & 8 & 8 & 8 & 8 & 8 & 8 & 8 & 8 & 8 & 8 \\
\hline
\end{tabular}


Orta Anadolu Bölgesi’nde buğdayda Avrupa Sünesi (Eurygaster maura L. Hemiptera: Scutelleridae)’nin neden olduğu ürün kayıpları ve ekonomik zarar eşiğinin belirlenmesi

\section{EK 2}

Kabul edilebilir üst emgi oranı \%3'e göre dikkate alınması gereken ekonomik zarar eşiği değerleri

\begin{tabular}{|c|c|c|c|c|c|c|c|c|c|c|c|c|c|c|c|c|c|c|}
\hline \multirow{2}{*}{$\begin{array}{c}\text { Bitki sayısı } \\
\left(\text { adet } \mathbf{m}^{-2}\right)\end{array}$} & \multicolumn{18}{|c|}{ Tane sayısı (adet bașak ${ }^{-1}$ ) } \\
\hline & 17 & 18 & 19 & 20 & 21 & 22 & 23 & 24 & 25 & 26 & 27 & 28 & 29 & 30 & 31 & 32 & 33 & 34 \\
\hline 170 & 1 & 1 & 1 & 1 & 1 & 1 & 1 & 1 & 1 & 1 & 1 & 1 & 1 & 1 & 1 & 1 & 1 & 1 \\
\hline 175 & 1 & 1 & 1 & 1 & 1 & 1 & 1 & 1 & 1 & 1 & 1 & 1 & 1 & 2 & 2 & 2 & 2 & 2 \\
\hline 180 & 1 & 1 & 1 & 1 & 1 & 1 & 1 & 1 & 1 & 1 & 1 & 1 & 2 & 2 & 2 & 2 & 3 & 3 \\
\hline 185 & 1 & 1 & 1 & 1 & 1 & 1 & 1 & 1 & 1 & 1 & 1 & 1 & 2 & 2 & 2 & 3 & 3 & 3 \\
\hline 190 & 1 & 1 & 1 & 1 & 1 & 1 & 1 & 1 & 1 & 1 & 1 & 2 & 2 & 2 & 2 & 3 & 3 & 3 \\
\hline 195 & 1 & 1 & 1 & 1 & 1 & 1 & 1 & 1 & 1 & 1 & 1 & 2 & 2 & 2 & 2 & 3 & 3 & 3 \\
\hline 200 & 1 & 1 & 1 & 1 & 1 & 1 & 1 & 1 & 1 & 1 & 1 & 2 & 2 & 2 & 3 & 3 & 3 & 3 \\
\hline 205 & 1 & 1 & 1 & 1 & 1 & 1 & 1 & 1 & 1 & 1 & 2 & 2 & 2 & 2 & 3 & 3 & 3 & 3 \\
\hline 210 & 1 & 1 & 1 & 1 & 1 & 1 & 1 & 1 & 1 & 1 & 2 & 2 & 2 & 2 & 3 & 3 & 3 & 3 \\
\hline 215 & 1 & 1 & 1 & 1 & 1 & 1 & 1 & 1 & 1 & 1 & 2 & 2 & 2 & 3 & 3 & 3 & 3 & 3 \\
\hline 220 & 1 & 1 & 1 & 1 & 1 & 1 & 1 & 1 & 1 & 2 & 2 & 2 & 2 & 3 & 3 & 3 & 3 & 3 \\
\hline 225 & 1 & 1 & 1 & 1 & 1 & 1 & 1 & 1 & 1 & 2 & 2 & 2 & 3 & 3 & 3 & 3 & 3 & 3 \\
\hline 230 & 1 & 1 & 1 & 1 & 1 & 1 & 1 & 1 & 1 & 2 & 2 & 2 & 3 & 3 & 3 & 3 & 3 & 3 \\
\hline 235 & 1 & 1 & 1 & 1 & 1 & 1 & 1 & 1 & 2 & 2 & 2 & 2 & 3 & 3 & 3 & 3 & 3 & 3 \\
\hline 240 & 1 & 1 & 1 & 1 & 1 & 1 & 1 & 1 & 2 & 2 & 2 & 3 & 3 & 3 & 3 & 3 & 3 & 3 \\
\hline 245 & 1 & 1 & 1 & 1 & 1 & 1 & 1 & 2 & 2 & 2 & 2 & 3 & 3 & 3 & 3 & 3 & 3 & 3 \\
\hline 250 & 1 & 1 & 1 & 1 & 1 & 1 & 1 & 2 & 2 & 2 & 2 & 3 & 3 & 3 & 3 & 3 & 3 & 4 \\
\hline 255 & 1 & 1 & 1 & 1 & 1 & 1 & 1 & 2 & 2 & 2 & 3 & 3 & 3 & 3 & 3 & 3 & 3 & 5 \\
\hline 260 & 1 & 1 & 1 & 1 & 1 & 1 & 2 & 2 & 2 & 2 & 3 & 3 & 3 & 3 & 3 & 3 & 3 & 5 \\
\hline 265 & 1 & 1 & 1 & 1 & 1 & 1 & 2 & 2 & 2 & 2 & 3 & 3 & 3 & 3 & 3 & 3 & 4 & 5 \\
\hline 270 & 1 & 1 & 1 & 1 & 1 & 1 & 2 & 2 & 2 & 3 & 3 & 3 & 3 & 3 & 3 & 3 & 4 & 5 \\
\hline 275 & 1 & 1 & 1 & 1 & 1 & 2 & 2 & 2 & 2 & 3 & 3 & 3 & 3 & 3 & 4 & 4 & 5 & 5 \\
\hline 280 & 1 & 1 & 1 & 1 & 1 & 2 & 2 & 2 & 3 & 3 & 3 & 3 & 3 & 3 & 4 & 5 & 5 & 5 \\
\hline 285 & 1 & 1 & 1 & 1 & 1 & 2 & 2 & 2 & 3 & 3 & 3 & 3 & 3 & 3 & 4 & 5 & 5 & 5 \\
\hline 290 & 1 & 1 & 1 & 1 & 2 & 2 & 2 & 2 & 3 & 3 & 3 & 3 & 3 & 4 & 4 & 5 & 5 & 5 \\
\hline 295 & 1 & 1 & 1 & 1 & 2 & 2 & 2 & 3 & 3 & 3 & 3 & 3 & 3 & 4 & 5 & 5 & 5 & 5 \\
\hline 300 & 1 & 1 & 1 & 1 & 2 & 2 & 2 & 3 & 3 & 3 & 3 & 3 & 3 & 4 & 5 & 5 & 5 & 6 \\
\hline 305 & 1 & 1 & 1 & 2 & 2 & 2 & 2 & 3 & 3 & 3 & 3 & 3 & 4 & 4 & 5 & 5 & 5 & 6 \\
\hline 310 & 1 & 1 & 1 & 2 & 2 & 2 & 3 & 3 & 3 & 3 & 3 & 3 & 4 & 5 & 5 & 5 & 5 & 6 \\
\hline 315 & 1 & 1 & 2 & 2 & 2 & 2 & 3 & 3 & 3 & 3 & 3 & 3 & 4 & 5 & 5 & 5 & 6 & 6 \\
\hline 320 & 1 & 1 & 2 & 2 & 2 & 2 & 3 & 3 & 3 & 3 & 3 & 4 & 4 & 5 & 5 & 5 & 6 & 6 \\
\hline 325 & 1 & 1 & 2 & 2 & 2 & 3 & 3 & 3 & 3 & 3 & 3 & 4 & 5 & 5 & 5 & 5 & 6 & 6 \\
\hline 330 & 1 & 2 & 2 & 2 & 2 & 3 & 3 & 3 & 3 & 3 & 3 & 4 & 5 & 5 & 5 & 6 & 6 & 6 \\
\hline 335 & 1 & 2 & 2 & 2 & 3 & 3 & 3 & 3 & 3 & 3 & 4 & 4 & 5 & 5 & 5 & 6 & 6 & 6 \\
\hline 340 & 1 & 2 & 2 & 2 & 3 & 3 & 3 & 3 & 3 & 3 & 4 & 5 & 5 & 5 & 5 & 6 & 6 & 6 \\
\hline 345 & 2 & 2 & 2 & 2 & 3 & 3 & 3 & 3 & 3 & 3 & 4 & 5 & 5 & 5 & 6 & 6 & 6 & 6 \\
\hline 350 & 2 & 2 & 2 & 3 & 3 & 3 & 3 & 3 & 3 & 4 & 5 & 5 & 5 & 5 & 6 & 6 & 6 & 7 \\
\hline 355 & 2 & 2 & 2 & 3 & 3 & 3 & 3 & 3 & 3 & 4 & 5 & 5 & 5 & 5 & 6 & 6 & 6 & 7 \\
\hline 360 & 2 & 2 & 2 & 3 & 3 & 3 & 3 & 3 & 3 & 4 & 5 & 5 & 5 & 6 & 6 & 6 & 6 & 7 \\
\hline 365 & 2 & 2 & 3 & 3 & 3 & 3 & 3 & 3 & 3 & 4 & 5 & 5 & 5 & 6 & 6 & 6 & 7 & 7 \\
\hline 370 & 2 & 2 & 3 & 3 & 3 & 3 & 3 & 3 & 4 & 5 & 5 & 5 & 6 & 6 & 6 & 6 & 7 & 7 \\
\hline 375 & 2 & 2 & 3 & 3 & 3 & 3 & 3 & 3 & 4 & 5 & 5 & 5 & 6 & 6 & 6 & 6 & 7 & 7 \\
\hline 380 & 2 & 3 & 3 & 3 & 3 & 3 & 3 & 4 & 5 & 5 & 5 & 5 & 6 & 6 & 6 & 7 & 7 & 7 \\
\hline 385 & 2 & 3 & 3 & 3 & 3 & 3 & 4 & 4 & 5 & 5 & 5 & 6 & 6 & 6 & 6 & 7 & 7 & 7 \\
\hline 390 & 2 & 3 & 3 & 3 & 3 & 4 & 4 & 5 & 5 & 5 & 5 & 6 & 6 & 6 & 7 & 7 & 7 & 7 \\
\hline 395 & 3 & 3 & 3 & 3 & 3 & 4 & 4 & 5 & 5 & 5 & 5 & 6 & 6 & 6 & 7 & 7 & 7 & 7 \\
\hline 400 & 3 & 3 & 3 & 3 & 3 & 4 & 4 & 5 & 5 & 5 & 6 & 6 & 6 & 6 & 7 & 7 & 7 & 7 \\
\hline 405 & 3 & 3 & 3 & 3 & 4 & 4 & 5 & 5 & 5 & 5 & 6 & 6 & 6 & 7 & 7 & 7 & 7 & 8 \\
\hline 410 & 3 & 3 & 3 & 3 & 4 & 4 & 5 & 5 & 5 & 5 & 6 & 6 & 6 & 7 & 7 & 7 & 7 & 8 \\
\hline
\end{tabular}




\section{EK 2 Devam}

Kabul edilebilir üst emgi oranı \%3'e göre dikkate alınması gereken ekonomik zarar eşiği değerleri

\begin{tabular}{|c|c|c|c|c|c|c|c|c|c|c|c|c|c|c|c|c|c|c|}
\hline \multirow{2}{*}{$\begin{array}{l}\text { Bitki sayısı } \\
\left(\text { adet } \mathbf{m}^{-2}\right)\end{array}$} & \multicolumn{18}{|c|}{ Tane sayısı (adet başak ${ }^{-1}$ ) } \\
\hline & 17 & 18 & 19 & 20 & 21 & 22 & 23 & 24 & 25 & 26 & 27 & 28 & 29 & 30 & 31 & 32 & 33 & 34 \\
\hline 415 & 3 & 3 & 3 & 3 & 4 & 4 & 5 & 5 & 5 & 6 & 6 & 6 & 6 & 7 & 7 & 7 & 8 & 8 \\
\hline 420 & 3 & 3 & 3 & 3 & 4 & 5 & 5 & 5 & 5 & 6 & 6 & 6 & 7 & 7 & 7 & 7 & 8 & 8 \\
\hline 425 & 3 & 3 & 3 & 4 & 4 & 5 & 5 & 5 & 6 & 6 & 6 & 6 & 7 & 7 & 7 & 8 & 8 & 8 \\
\hline 430 & 3 & 3 & 3 & 4 & 4 & 5 & 5 & 5 & 6 & 6 & 6 & 6 & 7 & 7 & 7 & 8 & 8 & 8 \\
\hline 435 & 3 & 3 & 3 & 4 & 5 & 5 & 5 & 5 & 6 & 6 & 6 & 7 & 7 & 7 & 7 & 8 & 8 & 8 \\
\hline 440 & 3 & 3 & 3 & 4 & 5 & 5 & 5 & 6 & 6 & 6 & 6 & 7 & 7 & 7 & 8 & 8 & 8 & 8 \\
\hline 445 & 3 & 3 & 3 & 4 & 5 & 5 & 5 & 6 & 6 & 6 & 7 & 7 & 7 & 7 & 8 & 8 & 8 & 9 \\
\hline 450 & 3 & 3 & 4 & 5 & 5 & 5 & 5 & 6 & 6 & 6 & 7 & 7 & 7 & 7 & 8 & 8 & 8 & 9 \\
\hline 455 & 3 & 3 & 4 & 5 & 5 & 5 & 6 & 6 & 6 & 6 & 7 & 7 & 7 & 8 & 8 & 8 & 9 & 9 \\
\hline 460 & 3 & 4 & 5 & 5 & 5 & 5 & 6 & 6 & 6 & 7 & 7 & 7 & 7 & 8 & 8 & 8 & 9 & 9 \\
\hline 465 & 3 & 4 & 5 & 5 & 5 & 5 & 6 & 6 & 6 & 7 & 7 & 7 & 7 & 8 & 8 & 8 & 9 & 9 \\
\hline 470 & 3 & 4 & 5 & 5 & 5 & 6 & 6 & 6 & 6 & 7 & 7 & 7 & 8 & 8 & 8 & 8 & 9 & 9 \\
\hline 475 & 4 & 5 & 5 & 5 & 5 & 6 & 6 & 6 & 7 & 7 & 7 & 7 & 8 & 8 & 8 & 9 & 9 & 9 \\
\hline 480 & 4 & 5 & 5 & 5 & 6 & 6 & 6 & 6 & 7 & 7 & 7 & 8 & 8 & 8 & 8 & 9 & 9 & 9 \\
\hline 485 & 4 & 5 & 5 & 5 & 6 & 6 & 6 & 6 & 7 & 7 & 7 & 8 & 8 & 8 & 8 & 9 & 9 & 9 \\
\hline 490 & 5 & 5 & 5 & 5 & 6 & 6 & 6 & 7 & 7 & 7 & 7 & 8 & 8 & 8 & 9 & 9 & 9 & 9 \\
\hline 495 & 5 & 5 & 5 & 6 & 6 & 6 & 6 & 7 & 7 & 7 & 8 & 8 & 8 & 8 & 9 & 9 & 9 & 10 \\
\hline 500 & 5 & 5 & 5 & 6 & 6 & 6 & 6 & 7 & 7 & 7 & 8 & 8 & 8 & 8 & 9 & 9 & 9 & 10 \\
\hline 505 & 5 & 5 & 5 & 6 & 6 & 6 & 7 & 7 & 7 & 7 & 8 & 8 & 8 & 9 & 9 & 9 & 9 & 10 \\
\hline 510 & 5 & 5 & 6 & 6 & 6 & 6 & 7 & 7 & 7 & 8 & 8 & 8 & 8 & 9 & 9 & 9 & 10 & 10 \\
\hline 515 & 5 & 5 & 6 & 6 & 6 & 7 & 7 & 7 & 7 & 8 & 8 & 8 & 9 & 9 & 9 & 9 & 10 & 10 \\
\hline 520 & 5 & 5 & 6 & 6 & 6 & 7 & 7 & 7 & 7 & 8 & 8 & 8 & 9 & 9 & 9 & 9 & 10 & 10 \\
\hline 525 & 5 & 6 & 6 & 6 & 6 & 7 & 7 & 7 & 8 & 8 & 8 & 9 & 9 & 9 & 9 & 10 & 10 & 10 \\
\hline 530 & 5 & 6 & 6 & 6 & 7 & 7 & 7 & 7 & 8 & 8 & 8 & 9 & 9 & 9 & 9 & 10 & 10 & 10 \\
\hline 535 & 5 & 6 & 6 & 6 & 7 & 7 & 7 & 8 & 8 & 8 & 8 & 9 & 9 & 9 & 10 & 10 & 10 & 10 \\
\hline 540 & 6 & 6 & 6 & 6 & 7 & 7 & 7 & 8 & 8 & 8 & 8 & 9 & 9 & 9 & 10 & 10 & 10 & 10 \\
\hline 545 & 6 & 6 & 6 & 7 & 7 & 7 & 7 & 8 & 8 & 8 & 9 & 9 & 9 & 9 & 10 & 10 & 10 & 11 \\
\hline 550 & 6 & 6 & 6 & 7 & 7 & 7 & 8 & 8 & 8 & 8 & 9 & 9 & 9 & 10 & 10 & 10 & 10 & 11 \\
\hline 555 & 6 & 6 & 6 & 7 & 7 & 7 & 8 & 8 & 8 & 8 & 9 & 9 & 9 & 10 & 10 & 10 & 10 & 11 \\
\hline 560 & 6 & 6 & 7 & 7 & 7 & 7 & 8 & 8 & 8 & 9 & 9 & 9 & 9 & 10 & 10 & 10 & 11 & 11 \\
\hline 565 & 6 & 6 & 7 & 7 & 7 & 8 & 8 & 8 & 8 & 9 & 9 & 9 & 10 & 10 & 10 & 10 & 11 & 11 \\
\hline 570 & 6 & 7 & 7 & 7 & 7 & 8 & 8 & 8 & 9 & 9 & 9 & 9 & 10 & 10 & 10 & 11 & 11 & 11 \\
\hline 575 & 6 & 7 & 7 & 7 & 7 & 8 & 8 & 8 & 9 & 9 & 9 & 9 & 10 & 10 & 10 & 11 & 11 & 11 \\
\hline 580 & 6 & 7 & 7 & 7 & 8 & 8 & 8 & 8 & 9 & 9 & 9 & 10 & 10 & 10 & 10 & 11 & 11 & 11 \\
\hline 585 & 7 & 7 & 7 & 7 & 8 & 8 & 8 & 9 & 9 & 9 & 9 & 10 & 10 & 10 & 11 & 11 & 11 & 11 \\
\hline 590 & 7 & 7 & 7 & 7 & 8 & 8 & 8 & 9 & 9 & 9 & 10 & 10 & 10 & 10 & 11 & 11 & 11 & 12 \\
\hline 595 & 7 & 7 & 7 & 8 & 8 & 8 & 8 & 9 & 9 & 9 & 10 & 10 & 10 & 10 & 11 & 11 & 11 & 12 \\
\hline 600 & 7 & 7 & 7 & 8 & 8 & 8 & 9 & 9 & 9 & 9 & 10 & 10 & 10 & 11 & 11 & 11 & 11 & 12 \\
\hline 605 & 7 & 7 & 8 & 8 & 8 & 8 & 9 & 9 & 9 & 10 & 10 & 10 & 10 & 11 & 11 & 11 & 12 & 12 \\
\hline 610 & 7 & 7 & 8 & 8 & 8 & 8 & 9 & 9 & 9 & 10 & 10 & 10 & 10 & 11 & 11 & 11 & 12 & 12 \\
\hline 615 & 7 & 7 & 8 & 8 & 8 & 9 & 9 & 9 & 9 & 10 & 10 & 10 & 11 & 11 & 11 & 11 & 12 & 12 \\
\hline 620 & 7 & 8 & 8 & 8 & 8 & 9 & 9 & 9 & 10 & 10 & 10 & 10 & 11 & 11 & 11 & 12 & 12 & 12 \\
\hline 625 & 7 & 8 & 8 & 8 & 9 & 9 & 9 & 9 & 10 & 10 & 10 & 11 & 11 & 11 & 11 & 12 & 12 & 12 \\
\hline 630 & 7 & 8 & 8 & 8 & 9 & 9 & 9 & 9 & 10 & 10 & 10 & 11 & 11 & 11 & 11 & 12 & 12 & 12 \\
\hline 635 & 8 & 8 & 8 & 8 & 9 & 9 & 9 & 10 & 10 & 10 & 10 & 11 & 11 & 11 & 12 & 12 & 12 & 12 \\
\hline 640 & 8 & 8 & 8 & 9 & 9 & 9 & 9 & 10 & 10 & 10 & 11 & 11 & 11 & 11 & 12 & 12 & 12 & 13 \\
\hline 645 & 8 & 8 & 8 & 9 & 9 & 9 & 9 & 10 & 10 & 10 & 11 & 11 & 11 & 12 & 12 & 12 & 12 & 13 \\
\hline 650 & 8 & 8 & 8 & 9 & 9 & 9 & 10 & 10 & 10 & 10 & 11 & 11 & 11 & 12 & 12 & 12 & 12 & 13 \\
\hline
\end{tabular}


Orta Anadolu Bölgesi’nde buğdayda Avrupa Sünesi (Eurygaster maura L. Hemiptera: Scutelleridae)’nin neden olduğu ürün kayıpları ve ekonomik zarar eşiğinin belirlenmesi

\section{EK 3}

Kabul edilebilir üst emgi oranı $\% 3,5$ 'e göre dikkate alınması gereken ekonomik zarar eşiği değerleri

\begin{tabular}{|c|c|c|c|c|c|c|c|c|c|c|c|c|c|c|c|c|c|c|}
\hline \multirow{2}{*}{$\begin{array}{l}\text { Bitki sayısı } \\
\text { (adet } \mathbf{m}^{-2} \text { ) }\end{array}$} & \multicolumn{18}{|c|}{ Tane sayısı (adet başak ${ }^{-1}$ ) } \\
\hline & 17 & 18 & 19 & 20 & 21 & 22 & 23 & 24 & 25 & 26 & 27 & 28 & 29 & 30 & 31 & 32 & 33 & 34 \\
\hline 170 & 1 & 1 & 1 & 1 & 1 & 1 & 1 & 1 & 1 & 1 & 1 & 2 & 2 & 2 & 2 & 3 & 3 & 3 \\
\hline 175 & 1 & 1 & 1 & 1 & 1 & 1 & 1 & 1 & 1 & 1 & 1 & 2 & 2 & 2 & 3 & 3 & 3 & 4 \\
\hline 180 & 1 & 1 & 1 & 1 & 1 & 1 & 1 & 1 & 1 & 1 & 2 & 2 & 2 & 2 & 3 & 3 & 3 & 4 \\
\hline 185 & 1 & 1 & 1 & 1 & 1 & 1 & 1 & 1 & 1 & 1 & 2 & 2 & 2 & 3 & 3 & 3 & 4 & 4 \\
\hline 190 & 1 & 1 & 1 & 1 & 1 & 1 & 1 & 1 & 1 & 1 & 2 & 2 & 2 & 3 & 3 & 3 & 4 & 4 \\
\hline 195 & 1 & 1 & 1 & 1 & 1 & 1 & 1 & 1 & 1 & 2 & 2 & 2 & 3 & 3 & 3 & 3 & 4 & 4 \\
\hline 200 & 1 & 1 & 1 & 1 & 1 & 1 & 1 & 1 & 1 & 2 & 2 & 2 & 3 & 3 & 3 & 4 & 4 & 4 \\
\hline 205 & 1 & 1 & 1 & 1 & 1 & 1 & 1 & 1 & 2 & 2 & 2 & 3 & 3 & 3 & 3 & 4 & 4 & 4 \\
\hline 210 & 1 & 1 & 1 & 1 & 1 & 1 & 1 & 1 & 2 & 2 & 2 & 3 & 3 & 3 & 4 & 4 & 4 & 5 \\
\hline 215 & 1 & 1 & 1 & 1 & 1 & 1 & 1 & 2 & 2 & 2 & 2 & 3 & 3 & 3 & 4 & 4 & 4 & 5 \\
\hline 220 & 1 & 1 & 1 & 1 & 1 & 1 & 1 & 2 & 2 & 2 & 3 & 3 & 3 & 4 & 4 & 4 & 4 & 5 \\
\hline 225 & 1 & 1 & 1 & 1 & 1 & 1 & 1 & 2 & 2 & 2 & 3 & 3 & 3 & 4 & 4 & 4 & 5 & 5 \\
\hline 230 & 1 & 1 & 1 & 1 & 1 & 1 & 2 & 2 & 2 & 3 & 3 & 3 & 3 & 4 & 4 & 4 & 5 & 5 \\
\hline 235 & 1 & 1 & 1 & 1 & 1 & 1 & 2 & 2 & 2 & 3 & 3 & 3 & 4 & 4 & 4 & 5 & 5 & 5 \\
\hline 240 & 1 & 1 & 1 & 1 & 1 & 2 & 2 & 2 & 3 & 3 & 3 & 3 & 4 & 4 & 4 & 5 & 5 & 5 \\
\hline 245 & 1 & 1 & 1 & 1 & 1 & 2 & 2 & 2 & 3 & 3 & 3 & 4 & 4 & 4 & 5 & 5 & 5 & 5 \\
\hline 250 & 1 & 1 & 1 & 1 & 2 & 2 & 2 & 2 & 3 & 3 & 3 & 4 & 4 & 4 & 5 & 5 & 5 & 6 \\
\hline 255 & 1 & 1 & 1 & 1 & 2 & 2 & 2 & 3 & 3 & 3 & 4 & 4 & 4 & 4 & 5 & 5 & 5 & 6 \\
\hline 260 & 1 & 1 & 1 & 2 & 2 & 2 & 2 & 3 & 3 & 3 & 4 & 4 & 4 & 5 & 5 & 5 & 6 & 6 \\
\hline 265 & 1 & 1 & 1 & 2 & 2 & 2 & 3 & 3 & 3 & 4 & 4 & 4 & 4 & 5 & 5 & 5 & 6 & 6 \\
\hline 270 & 1 & 1 & 1 & 2 & 2 & 2 & 3 & 3 & 3 & 4 & 4 & 4 & 5 & 5 & 5 & 5 & 6 & 6 \\
\hline 275 & 1 & 1 & 2 & 2 & 2 & 3 & 3 & 3 & 3 & 4 & 4 & 4 & 5 & 5 & 5 & 6 & 6 & 6 \\
\hline 280 & 1 & 1 & 2 & 2 & 2 & 3 & 3 & 3 & 4 & 4 & 4 & 5 & 5 & 5 & 5 & 6 & 6 & 6 \\
\hline 285 & 1 & 2 & 2 & 2 & 2 & 3 & 3 & 3 & 4 & 4 & 4 & 5 & 5 & 5 & 6 & 6 & 6 & 7 \\
\hline 290 & 1 & 2 & 2 & 2 & 3 & 3 & 3 & 4 & 4 & 4 & 4 & 5 & 5 & 5 & 6 & 6 & 6 & 7 \\
\hline 295 & 2 & 2 & 2 & 2 & 3 & 3 & 3 & 4 & 4 & 4 & 5 & 5 & 5 & 6 & 6 & 6 & 6 & 7 \\
\hline 300 & 2 & 2 & 2 & 3 & 3 & 3 & 4 & 4 & 4 & 4 & 5 & 5 & 5 & 6 & 6 & 6 & 7 & 7 \\
\hline 305 & 2 & 2 & 2 & 3 & 3 & 3 & 4 & 4 & 4 & 5 & 5 & 5 & 6 & 6 & 6 & 6 & 7 & 7 \\
\hline 310 & 2 & 2 & 3 & 3 & 3 & 3 & 4 & 4 & 4 & 5 & 5 & 5 & 6 & 6 & 6 & 7 & 7 & 7 \\
\hline 315 & 2 & 2 & 3 & 3 & 3 & 4 & 4 & 4 & 5 & 5 & 5 & 5 & 6 & 6 & 6 & 7 & 7 & 7 \\
\hline 320 & 2 & 3 & 3 & 3 & 3 & 4 & 4 & 4 & 5 & 5 & 5 & 6 & 6 & 6 & 7 & 7 & 7 & 7 \\
\hline 325 & 2 & 3 & 3 & 3 & 4 & 4 & 4 & 4 & 5 & 5 & 5 & 6 & 6 & 6 & 7 & 7 & 7 & 8 \\
\hline 330 & 3 & 3 & 3 & 3 & 4 & 4 & 4 & 5 & 5 & 5 & 6 & 6 & 6 & 6 & 7 & 7 & 7 & 8 \\
\hline 335 & 3 & 3 & 3 & 4 & 4 & 4 & 4 & 5 & 5 & 5 & 6 & 6 & 6 & 7 & 7 & 7 & 8 & 8 \\
\hline 340 & 3 & 3 & 3 & 4 & 4 & 4 & 5 & 5 & 5 & 6 & 6 & 6 & 6 & 7 & 7 & 7 & 8 & 8 \\
\hline 345 & 3 & 3 & 3 & 4 & 4 & 4 & 5 & 5 & 5 & 6 & 6 & 6 & 7 & 7 & 7 & 8 & 8 & 8 \\
\hline 350 & 3 & 3 & 4 & 4 & 4 & 5 & 5 & 5 & 5 & 6 & 6 & 6 & 7 & 7 & 7 & 8 & 8 & 8 \\
\hline 355 & 3 & 3 & 4 & 4 & 4 & 5 & 5 & 5 & 6 & 6 & 6 & 7 & 7 & 7 & 7 & 8 & 8 & 8 \\
\hline 360 & 3 & 4 & 4 & 4 & 5 & 5 & 5 & 5 & 6 & 6 & 6 & 7 & 7 & 7 & 8 & 8 & 8 & 9 \\
\hline 365 & 3 & 4 & 4 & 4 & 5 & 5 & 5 & 6 & 6 & 6 & 7 & 7 & 7 & 7 & 8 & 8 & 8 & 9 \\
\hline 370 & 4 & 4 & 4 & 4 & 5 & 5 & 5 & 6 & 6 & 6 & 7 & 7 & 7 & 8 & 8 & 8 & 8 & 9 \\
\hline 375 & 4 & 4 & 4 & 5 & 5 & 5 & 6 & 6 & 6 & 6 & 7 & 7 & 7 & 8 & 8 & 8 & 9 & 9 \\
\hline 380 & 4 & 4 & 4 & 5 & 5 & 5 & 6 & 6 & 6 & 7 & 7 & 7 & 8 & 8 & 8 & 8 & 9 & 9 \\
\hline 385 & 4 & 4 & 5 & 5 & 5 & 5 & 6 & 6 & 6 & 7 & 7 & 7 & 8 & 8 & 8 & 9 & 9 & 9 \\
\hline 390 & 4 & 4 & 5 & 5 & 5 & 6 & 6 & 6 & 7 & 7 & 7 & 7 & 8 & 8 & 8 & 9 & 9 & 9 \\
\hline 395 & 4 & 5 & 5 & 5 & 5 & 6 & 6 & 6 & 7 & 7 & 7 & 8 & 8 & 8 & 9 & 9 & 9 & 9 \\
\hline 400 & 4 & 5 & 5 & 5 & 6 & 6 & 6 & 7 & 7 & 7 & 7 & 8 & 8 & 8 & 9 & 9 & 9 & 10 \\
\hline 405 & 4 & 5 & 5 & 5 & 6 & 6 & 6 & 7 & 7 & 7 & 8 & 8 & 8 & 9 & 9 & 9 & 9 & 10 \\
\hline 410 & 5 & 5 & 5 & 6 & 6 & 6 & 6 & 7 & 7 & 7 & 8 & 8 & 8 & 9 & 9 & 9 & 10 & 10 \\
\hline
\end{tabular}




\section{EK 3 Devam}

Kabul edilebilir üst emgi oranı $\% 3,5$ 'e göre dikkate alınması gereken ekonomik zarar eşiği değerleri

\begin{tabular}{|c|c|c|c|c|c|c|c|c|c|c|c|c|c|c|c|c|c|c|}
\hline \multirow{2}{*}{ 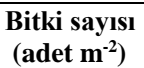 } & \multicolumn{18}{|c|}{ Tane sayısı (adet başak ${ }^{-1}$ ) } \\
\hline & 17 & 18 & 19 & 20 & 21 & 22 & 23 & 24 & 25 & 26 & 27 & 28 & 29 & 30 & 31 & 32 & 33 & 34 \\
\hline 415 & 5 & 5 & 5 & 6 & 6 & 6 & 7 & 7 & 7 & 8 & 8 & 8 & 8 & 9 & 9 & 9 & 10 & 10 \\
\hline 420 & 5 & 5 & 6 & 6 & 6 & 6 & 7 & 7 & 7 & 8 & 8 & 8 & 9 & 9 & 9 & 10 & 10 & 10 \\
\hline 425 & 5 & 5 & 6 & 6 & 6 & 7 & 7 & 7 & 7 & 8 & 8 & 8 & 9 & 9 & 9 & 10 & 10 & 10 \\
\hline 430 & 5 & 5 & 6 & 6 & 6 & 7 & 7 & 7 & 8 & 8 & 8 & 9 & 9 & 9 & 9 & 10 & 10 & 10 \\
\hline 435 & 5 & 6 & 6 & 6 & 7 & 7 & 7 & 7 & 8 & 8 & 8 & 9 & 9 & 9 & 10 & 10 & 10 & 11 \\
\hline 440 & 5 & 6 & 6 & 6 & 7 & 7 & 7 & 8 & 8 & 8 & 9 & 9 & 9 & 9 & 10 & 10 & 10 & 11 \\
\hline 445 & 6 & 6 & 6 & 6 & 7 & 7 & 7 & 8 & 8 & 8 & 9 & 9 & 9 & 10 & 10 & 10 & 11 & 11 \\
\hline 450 & 6 & 6 & 6 & 7 & 7 & 7 & 8 & 8 & 8 & 8 & 9 & 9 & 9 & 10 & 10 & 10 & 11 & 11 \\
\hline 455 & 6 & 6 & 6 & 7 & 7 & 7 & 8 & 8 & 8 & 9 & 9 & 9 & 10 & 10 & 10 & 10 & 11 & 11 \\
\hline 460 & 6 & 6 & 7 & 7 & 7 & 8 & 8 & 8 & 8 & 9 & 9 & 9 & 10 & 10 & 10 & 11 & 11 & 11 \\
\hline 465 & 6 & 6 & 7 & 7 & 7 & 8 & 8 & 8 & 9 & 9 & 9 & 10 & 10 & 10 & 10 & 11 & 11 & 11 \\
\hline 470 & 6 & 7 & 7 & 7 & 7 & 8 & 8 & 8 & 9 & 9 & 9 & 10 & 10 & 10 & 11 & 11 & 11 & 11 \\
\hline 475 & 6 & 7 & 7 & 7 & 8 & 8 & 8 & 9 & 9 & 9 & 9 & 10 & 10 & 10 & 11 & 11 & 11 & 12 \\
\hline 480 & 6 & 7 & 7 & 7 & 8 & 8 & 8 & 9 & 9 & 9 & 10 & 10 & 10 & 11 & 11 & 11 & 11 & 12 \\
\hline 485 & 7 & 7 & 7 & 8 & 8 & 8 & 8 & 9 & 9 & 9 & 10 & 10 & 10 & 11 & 11 & 11 & 12 & 12 \\
\hline 490 & 7 & 7 & 7 & 8 & 8 & 8 & 9 & 9 & 9 & 10 & 10 & 10 & 10 & 11 & 11 & 11 & 12 & 12 \\
\hline 495 & 7 & 7 & 8 & 8 & 8 & 8 & 9 & 9 & 9 & 10 & 10 & 10 & 11 & 11 & 11 & 12 & 12 & 12 \\
\hline 500 & 7 & 7 & 8 & 8 & 8 & 9 & 9 & 9 & 10 & 10 & 10 & 10 & 11 & 11 & 11 & 12 & 12 & 12 \\
\hline 505 & 7 & 7 & 8 & 8 & 8 & 9 & 9 & 9 & 10 & 10 & 10 & 11 & 11 & 11 & 12 & 12 & 12 & 12 \\
\hline 510 & 7 & 8 & 8 & 8 & 9 & 9 & 9 & 9 & 10 & 10 & 10 & 11 & 11 & 11 & 12 & 12 & 12 & 13 \\
\hline 515 & 7 & 8 & 8 & 8 & 9 & 9 & 9 & 10 & 10 & 10 & 11 & 11 & 11 & 11 & 12 & 12 & 12 & 13 \\
\hline 520 & 8 & 8 & 8 & 8 & 9 & 9 & 9 & 10 & 10 & 10 & 11 & 11 & 11 & 12 & 12 & 12 & 13 & 13 \\
\hline 525 & 8 & 8 & 8 & 9 & 9 & 9 & 10 & 10 & 10 & 10 & 11 & 11 & 11 & 12 & 12 & 12 & 13 & 13 \\
\hline 530 & 8 & 8 & 8 & 9 & 9 & 9 & 10 & 10 & 10 & 11 & 11 & 11 & 12 & 12 & 12 & 12 & 13 & 13 \\
\hline 535 & 8 & 8 & 9 & 9 & 9 & 10 & 10 & 10 & 10 & 11 & 11 & 11 & 12 & 12 & 12 & 13 & 13 & 13 \\
\hline 540 & 8 & 8 & 9 & 9 & 9 & 10 & 10 & 10 & 11 & 11 & 11 & 12 & 12 & 12 & 12 & 13 & 13 & 13 \\
\hline 545 & 8 & 9 & 9 & 9 & 9 & 10 & 10 & 10 & 11 & 11 & 11 & 12 & 12 & 12 & 13 & 13 & 13 & 14 \\
\hline 550 & 8 & 9 & 9 & 9 & 10 & 10 & 10 & 11 & 11 & 11 & 11 & 12 & 12 & 12 & 13 & 13 & 13 & 14 \\
\hline 555 & 9 & 9 & 9 & 9 & 10 & 10 & 10 & 11 & 11 & 11 & 12 & 12 & 12 & 13 & 13 & 13 & 13 & 14 \\
\hline 560 & 9 & 9 & 9 & 10 & 10 & 10 & 11 & 11 & 11 & 11 & 12 & 12 & 12 & 13 & 13 & 13 & 14 & 14 \\
\hline 565 & 9 & 9 & 9 & 10 & 10 & 10 & 11 & 11 & 11 & 12 & 12 & 12 & 12 & 13 & 13 & 13 & 14 & 14 \\
\hline 570 & 9 & 9 & 10 & 10 & 10 & 10 & 11 & 11 & 11 & 12 & 12 & 12 & 13 & 13 & 13 & 14 & 14 & 14 \\
\hline 575 & 9 & 9 & 10 & 10 & 10 & 11 & 11 & 11 & 12 & 12 & 12 & 12 & 13 & 13 & 13 & 14 & 14 & 14 \\
\hline 580 & 9 & 9 & 10 & 10 & 10 & 11 & 11 & 11 & 12 & 12 & 12 & 13 & 13 & 13 & 14 & 14 & 14 & 14 \\
\hline 585 & 9 & 10 & 10 & 10 & 11 & 11 & 11 & 11 & 12 & 12 & 12 & 13 & 13 & 13 & 14 & 14 & 14 & 15 \\
\hline 590 & 9 & 10 & 10 & 10 & 11 & 11 & 11 & 12 & 12 & 12 & 13 & 13 & 13 & 13 & 14 & 14 & 14 & 15 \\
\hline 595 & 10 & 10 & 10 & 11 & 11 & 11 & 11 & 12 & 12 & 12 & 13 & 13 & 13 & 14 & 14 & 14 & 15 & 15 \\
\hline 600 & 10 & 10 & 10 & 11 & 11 & 11 & 12 & 12 & 12 & 13 & 13 & 13 & 13 & 14 & 14 & 14 & 15 & 15 \\
\hline 605 & 10 & 10 & 10 & 11 & 11 & 11 & 12 & 12 & 12 & 13 & 13 & 13 & 14 & 14 & 14 & 15 & 15 & 15 \\
\hline 610 & 10 & 10 & 11 & 11 & 11 & 12 & 12 & 12 & 12 & 13 & 13 & 13 & 14 & 14 & 14 & 15 & 15 & 15 \\
\hline 615 & 10 & 10 & 11 & 11 & 11 & 12 & 12 & 12 & 13 & 13 & 13 & 14 & 14 & 14 & 14 & 15 & 15 & 15 \\
\hline 620 & 10 & 11 & 11 & 11 & 11 & 12 & 12 & 12 & 13 & 13 & 13 & 14 & 14 & 14 & 15 & 15 & 15 & 16 \\
\hline 625 & 10 & 11 & 11 & 11 & 12 & 12 & 12 & 13 & 13 & 13 & 13 & 14 & 14 & 14 & 15 & 15 & 15 & 16 \\
\hline 630 & 11 & 11 & 11 & 11 & 12 & 12 & 12 & 13 & 13 & 13 & 14 & 14 & 14 & 15 & 15 & 15 & 15 & 16 \\
\hline 635 & 11 & 11 & 11 & 12 & 12 & 12 & 13 & 13 & 13 & 13 & 14 & 14 & 14 & 15 & 15 & 15 & 16 & 16 \\
\hline 640 & 11 & 11 & 11 & 12 & 12 & 12 & 13 & 13 & 13 & 14 & 14 & 14 & 15 & 15 & 15 & 15 & 16 & 16 \\
\hline 645 & 11 & 11 & 12 & 12 & 12 & 12 & 13 & 13 & 13 & 14 & 14 & 14 & 15 & 15 & 15 & 16 & 16 & 16 \\
\hline 650 & 11 & 11 & 12 & 12 & 12 & 13 & 13 & 13 & 14 & 14 & 14 & 14 & 15 & 15 & 15 & 16 & 16 & 16 \\
\hline
\end{tabular}


Orta Anadolu Bölgesi’nde buğdayda Avrupa Sünesi (Eurygaster maura L. Hemiptera: Scutelleridae)’nin neden olduğu ürün kayıpları ve ekonomik zarar eşiğinin belirlenmesi

\section{EK 4}

Kabul edilebilir üst emgi oranı \%4'e göre dikkate alınması gereken ekonomik zarar eşiği değerleri

\begin{tabular}{|c|c|c|c|c|c|c|c|c|c|c|c|c|c|c|c|c|c|c|}
\hline \multirow{2}{*}{ 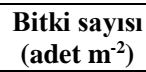 } & \multicolumn{18}{|c|}{ Tane sayısı (adet başak ${ }^{-1}$ ) } \\
\hline & 17 & 18 & 19 & 20 & 21 & 22 & 23 & 24 & 25 & 26 & 27 & 28 & 29 & 30 & 31 & 32 & 33 & 34 \\
\hline 170 & 1 & 1 & 1 & 1 & 1 & 1 & 1 & 1 & 1 & 1 & 1 & 1 & 1 & 2 & 2 & 2 & 3 & 3 \\
\hline 175 & 1 & 1 & 1 & 1 & 1 & 1 & 1 & 1 & 1 & 1 & 1 & 1 & 1 & 2 & 2 & 2 & 3 & 3 \\
\hline 180 & 1 & 1 & 1 & 1 & 1 & 1 & 1 & 1 & 1 & 1 & 1 & 1 & 2 & 2 & 2 & 3 & 3 & 3 \\
\hline 185 & 1 & 1 & 1 & 1 & 1 & 1 & 1 & 1 & 1 & 1 & 1 & 1 & 2 & 2 & 2 & 3 & 3 & 3 \\
\hline 190 & 1 & 1 & 1 & 1 & 1 & 1 & 1 & 1 & 1 & 1 & 1 & 2 & 2 & 2 & 3 & 3 & 3 & 4 \\
\hline 195 & 1 & 1 & 1 & 1 & 1 & 1 & 1 & 1 & 1 & 1 & 1 & 2 & 2 & 2 & 3 & 3 & 3 & 4 \\
\hline 200 & 1 & 1 & 1 & 1 & 1 & 1 & 1 & 1 & 1 & 1 & 1 & 2 & 2 & 3 & 3 & 3 & 4 & 4 \\
\hline 205 & 1 & 1 & 1 & 1 & 1 & 1 & 1 & 1 & 1 & 1 & 2 & 2 & 2 & 3 & 3 & 3 & 4 & 4 \\
\hline 210 & 1 & 1 & 1 & 1 & 1 & 1 & 1 & 1 & 1 & 1 & 2 & 2 & 3 & 3 & 3 & 4 & 4 & 4 \\
\hline 215 & 1 & 1 & 1 & 1 & 1 & 1 & 1 & 1 & 1 & 2 & 2 & 2 & 3 & 3 & 3 & 4 & 4 & 4 \\
\hline 220 & 1 & 1 & 1 & 1 & 1 & 1 & 1 & 1 & 1 & 2 & 2 & 2 & 3 & 3 & 4 & 4 & 4 & 5 \\
\hline 225 & 1 & 1 & 1 & 1 & 1 & 1 & 1 & 1 & 1 & 2 & 2 & 3 & 3 & 3 & 4 & 4 & 4 & 5 \\
\hline 230 & 1 & 1 & 1 & 1 & 1 & 1 & 1 & 1 & 2 & 2 & 2 & 3 & 3 & 3 & 4 & 4 & 5 & 5 \\
\hline 235 & 1 & 1 & 1 & 1 & 1 & 1 & 1 & 2 & 2 & 2 & 3 & 3 & 3 & 4 & 4 & 4 & 5 & 5 \\
\hline 240 & 1 & 1 & 1 & 1 & 1 & 1 & 1 & 2 & 2 & 2 & 3 & 3 & 3 & 4 & 4 & 5 & 5 & 5 \\
\hline 245 & 1 & 1 & 1 & 1 & 1 & 1 & 2 & 2 & 2 & 3 & 3 & 3 & 4 & 4 & 4 & 5 & 5 & 6 \\
\hline 250 & 1 & 1 & 1 & 1 & 1 & 1 & 2 & 2 & 2 & 3 & 3 & 3 & 4 & 4 & 4 & 5 & 5 & 6 \\
\hline 255 & 1 & 1 & 1 & 1 & 1 & 2 & 2 & 2 & 3 & 3 & 3 & 4 & 4 & 4 & 5 & 5 & 5 & 6 \\
\hline 260 & 1 & 1 & 1 & 1 & 1 & 2 & 2 & 2 & 3 & 3 & 3 & 4 & 4 & 4 & 5 & 5 & 6 & 6 \\
\hline 265 & 1 & 1 & 1 & 1 & 2 & 2 & 2 & 3 & 3 & 3 & 4 & 4 & 4 & 5 & 5 & 5 & 6 & 6 \\
\hline 270 & 1 & 1 & 1 & 1 & 2 & 2 & 2 & 3 & 3 & 3 & 4 & 4 & 4 & 5 & 5 & 5 & 6 & 6 \\
\hline 275 & 1 & 1 & 1 & 2 & 2 & 2 & 3 & 3 & 3 & 4 & 4 & 4 & 5 & 5 & 5 & 6 & 6 & 6 \\
\hline 280 & 1 & 1 & 1 & 2 & 2 & 2 & 3 & 3 & 3 & 4 & 4 & 4 & 5 & 5 & 5 & 6 & 6 & 6 \\
\hline 285 & 1 & 1 & 2 & 2 & 2 & 3 & 3 & 3 & 4 & 4 & 4 & 5 & 5 & 5 & 6 & 6 & 6 & 7 \\
\hline 290 & 1 & 1 & 2 & 2 & 3 & 3 & 3 & 3 & 4 & 4 & 4 & 5 & 5 & 5 & 6 & 6 & 6 & 7 \\
\hline 295 & 1 & 2 & 2 & 2 & 3 & 3 & 3 & 4 & 4 & 4 & 5 & 5 & 5 & 6 & 6 & 6 & 7 & 7 \\
\hline 300 & 1 & 2 & 2 & 2 & 3 & 3 & 3 & 4 & 4 & 4 & 5 & 5 & 5 & 6 & 6 & 6 & 7 & 7 \\
\hline 305 & 2 & 2 & 2 & 3 & 3 & 3 & 4 & 4 & 4 & 5 & 5 & 5 & 6 & 6 & 6 & 7 & 7 & 7 \\
\hline 310 & 2 & 2 & 2 & 3 & 3 & 3 & 4 & 4 & 4 & 5 & 5 & 5 & 6 & 6 & 6 & 7 & 7 & 7 \\
\hline 315 & 2 & 2 & 3 & 3 & 3 & 4 & 4 & 4 & 5 & 5 & 5 & 6 & 6 & 6 & 7 & 7 & 7 & 8 \\
\hline 320 & 2 & 2 & 3 & 3 & 3 & 4 & 4 & 4 & 5 & 5 & 5 & 6 & 6 & 6 & 7 & 7 & 7 & 8 \\
\hline 325 & 2 & 3 & 3 & 3 & 4 & 4 & 4 & 5 & 5 & 5 & 6 & 6 & 6 & 7 & 7 & 7 & 8 & 8 \\
\hline 330 & 2 & 3 & 3 & 3 & 4 & 4 & 4 & 5 & 5 & 5 & 6 & 6 & 6 & 7 & 7 & 7 & 8 & 8 \\
\hline 335 & 3 & 3 & 3 & 4 & 4 & 4 & 5 & 5 & 5 & 6 & 6 & 6 & 7 & 7 & 7 & 8 & 8 & 8 \\
\hline 340 & 3 & 3 & 3 & 4 & 4 & 4 & 5 & 5 & 5 & 6 & 6 & 6 & 7 & 7 & 7 & 8 & 8 & 8 \\
\hline 345 & 3 & 3 & 4 & 4 & 4 & 5 & 5 & 5 & 6 & 6 & 6 & 7 & 7 & 7 & 8 & 8 & 8 & 9 \\
\hline 350 & 3 & 3 & 4 & 4 & 4 & 5 & 5 & 5 & 6 & 6 & 6 & 7 & 7 & 7 & 8 & 8 & 8 & 9 \\
\hline 355 & 3 & 4 & 4 & 4 & 5 & 5 & 5 & 6 & 6 & 6 & 7 & 7 & 7 & 8 & 8 & 8 & 9 & 9 \\
\hline 360 & 3 & 4 & 4 & 4 & 5 & 5 & 5 & 6 & 6 & 6 & 7 & 7 & 7 & 8 & 8 & 8 & 9 & 9 \\
\hline 365 & 3 & 4 & 4 & 5 & 5 & 5 & 6 & 6 & 6 & 7 & 7 & 7 & 8 & 8 & 8 & 9 & 9 & 9 \\
\hline 370 & 4 & 4 & 4 & 5 & 5 & 5 & 6 & 6 & 6 & 7 & 7 & 7 & 8 & 8 & 8 & 9 & 9 & 9 \\
\hline 375 & 4 & 4 & 5 & 5 & 5 & 6 & 6 & 6 & 7 & 7 & 7 & 8 & 8 & 8 & 9 & 9 & 9 & 10 \\
\hline 380 & 4 & 4 & 5 & 5 & 5 & 6 & 6 & 6 & 7 & 7 & 7 & 8 & 8 & 8 & 9 & 9 & 9 & 10 \\
\hline 385 & 4 & 4 & 5 & 5 & 6 & 6 & 6 & 7 & 7 & 7 & 8 & 8 & 8 & 9 & 9 & 9 & 10 & 10 \\
\hline 390 & 4 & 5 & 5 & 5 & 6 & 6 & 6 & 7 & 7 & 7 & 8 & 8 & 8 & 9 & 9 & 9 & 10 & 10 \\
\hline 395 & 4 & 5 & 5 & 6 & 6 & 6 & 7 & 7 & 7 & 8 & 8 & 8 & 9 & 9 & 9 & 10 & 10 & 10 \\
\hline 400 & 5 & 5 & 5 & 6 & 6 & 6 & 7 & 7 & 7 & 8 & 8 & 8 & 9 & 9 & 9 & 10 & 10 & 10 \\
\hline 405 & 5 & 5 & 5 & 6 & 6 & 7 & 7 & 7 & 8 & 8 & 8 & 9 & 9 & 9 & 10 & 10 & 10 & 11 \\
\hline 410 & 5 & 5 & 6 & 6 & 6 & 7 & 7 & 7 & 8 & 8 & 8 & 9 & 9 & 9 & 10 & 10 & 10 & 11 \\
\hline
\end{tabular}




\section{EK 4 Devam}

Kabul edilebilir üst emgi oranı \%4'e göre dikkate alınması gereken ekonomik zarar eşiği değerleri

\begin{tabular}{|c|c|c|c|c|c|c|c|c|c|c|c|c|c|c|c|c|c|c|}
\hline \multirow{2}{*}{ 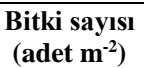 } & \multicolumn{18}{|c|}{ Tane sayısı (adet başak ${ }^{-1}$ ) } \\
\hline & 17 & 18 & 19 & 20 & 21 & 22 & 23 & 24 & 25 & 26 & 27 & 28 & 29 & 30 & 31 & 32 & 33 & 34 \\
\hline 415 & 5 & 5 & 6 & 6 & 6 & 7 & 7 & 7 & 8 & 8 & 9 & 9 & 9 & 10 & 10 & 10 & 11 & 11 \\
\hline 420 & 5 & 6 & 6 & 6 & 7 & 7 & 7 & 8 & 8 & 8 & 9 & 9 & 9 & 10 & 10 & 10 & 11 & 11 \\
\hline 425 & 5 & 6 & 6 & 6 & 7 & 7 & 7 & 8 & 8 & 9 & 9 & 9 & 10 & 10 & 10 & 11 & 11 & 11 \\
\hline 430 & 6 & 6 & 6 & 7 & 7 & 7 & 8 & 8 & 8 & 9 & 9 & 9 & 10 & 10 & 10 & 11 & 11 & 11 \\
\hline 435 & 6 & 6 & 6 & 7 & 7 & 7 & 8 & 8 & 9 & 9 & 9 & 10 & 10 & 10 & 11 & 11 & 11 & 12 \\
\hline 440 & 6 & 6 & 7 & 7 & 7 & 8 & 8 & 8 & 9 & 9 & 9 & 10 & 10 & 10 & 11 & 11 & 11 & 12 \\
\hline 445 & 6 & 6 & 7 & 7 & 7 & 8 & 8 & 9 & 9 & 9 & 10 & 10 & 10 & 11 & 11 & 11 & 12 & 12 \\
\hline 450 & 6 & 7 & 7 & 7 & 8 & 8 & 8 & 9 & 9 & 9 & 10 & 10 & 10 & 11 & 11 & 11 & 12 & 12 \\
\hline 455 & 6 & 7 & 7 & 7 & 8 & 8 & 8 & 9 & 9 & 10 & 10 & 10 & 11 & 11 & 11 & 12 & 12 & 12 \\
\hline 460 & 7 & 7 & 7 & 8 & 8 & 8 & 9 & 9 & 9 & 10 & 10 & 10 & 11 & 11 & 11 & 12 & 12 & 12 \\
\hline 465 & 7 & 7 & 7 & 8 & 8 & 8 & 9 & 9 & 10 & 10 & 10 & 11 & 11 & 11 & 12 & 12 & 12 & 13 \\
\hline 470 & 7 & 7 & 8 & 8 & 8 & 9 & 9 & 9 & 10 & 10 & 10 & 11 & 11 & 11 & 12 & 12 & 12 & 13 \\
\hline 475 & 7 & 7 & 8 & 8 & 8 & 9 & 9 & 9 & 10 & 10 & 11 & 11 & 11 & 11 & 12 & 12 & 13 & 13 \\
\hline 480 & 7 & 8 & 8 & 8 & 9 & 9 & 9 & 10 & 10 & 10 & 11 & 11 & 11 & 12 & 12 & 12 & 13 & 13 \\
\hline 485 & 7 & 8 & 8 & 8 & 9 & 9 & 9 & 10 & 10 & 10 & 11 & 11 & 11 & 12 & 12 & 13 & 13 & 13 \\
\hline 490 & 8 & 8 & 8 & 9 & 9 & 9 & 10 & 10 & 10 & 11 & 11 & 11 & 12 & 12 & 12 & 13 & 13 & 13 \\
\hline 495 & 8 & 8 & 8 & 9 & 9 & 9 & 10 & 10 & 10 & 11 & 11 & 11 & 12 & 12 & 13 & 13 & 13 & 14 \\
\hline 500 & 8 & 8 & 9 & 9 & 9 & 10 & 10 & 10 & 11 & 11 & 11 & 12 & 12 & 12 & 13 & 13 & 13 & 14 \\
\hline 505 & 8 & 8 & 9 & 9 & 9 & 10 & 10 & 10 & 11 & 11 & 11 & 12 & 12 & 13 & 13 & 13 & 14 & 14 \\
\hline 510 & 8 & 9 & 9 & 9 & 10 & 10 & 10 & 11 & 11 & 11 & 12 & 12 & 12 & 13 & 13 & 13 & 14 & 14 \\
\hline 515 & 8 & 9 & 9 & 9 & 10 & 10 & 10 & 11 & 11 & 11 & 12 & 12 & 13 & 13 & 13 & 14 & 14 & 14 \\
\hline 520 & 9 & 9 & 9 & 10 & 10 & 10 & 11 & 11 & 11 & 12 & 12 & 12 & 13 & 13 & 13 & 14 & 14 & 14 \\
\hline 525 & 9 & 9 & 9 & 10 & 10 & 10 & 11 & 11 & 11 & 12 & 12 & 12 & 13 & 13 & 14 & 14 & 14 & 15 \\
\hline 530 & 9 & 9 & 10 & 10 & 10 & 11 & 11 & 11 & 12 & 12 & 12 & 13 & 13 & 13 & 14 & 14 & 14 & 15 \\
\hline 535 & 9 & 9 & 10 & 10 & 10 & 11 & 11 & 11 & 12 & 12 & 12 & 13 & 13 & 13 & 14 & 14 & 15 & 15 \\
\hline 540 & 9 & 10 & 10 & 10 & 11 & 11 & 11 & 12 & 12 & 12 & 13 & 13 & 13 & 14 & 14 & 14 & 15 & 15 \\
\hline 545 & 9 & 10 & 10 & 10 & 11 & 11 & 11 & 12 & 12 & 12 & 13 & 13 & 13 & 14 & 14 & 15 & 15 & 15 \\
\hline 50 & 10 & 10 & 10 & 11 & 11 & 11 & 12 & 12 & 12 & 13 & 13 & 13 & 14 & 14 & 14 & 15 & 15 & 15 \\
\hline 555 & 10 & 10 & 10 & 11 & 11 & 11 & 12 & 12 & 12 & 13 & 13 & 13 & 14 & 14 & 14 & 15 & 15 & 16 \\
\hline 560 & 10 & 10 & 11 & 11 & 11 & 12 & 12 & 12 & 13 & 13 & 13 & 14 & 14 & 14 & 15 & 15 & 15 & 16 \\
\hline 565 & 10 & 10 & 11 & 11 & 11 & 12 & 12 & 12 & 13 & 13 & 13 & 14 & 14 & 14 & 15 & 15 & 16 & 16 \\
\hline 570 & 10 & 11 & 11 & 11 & 12 & 12 & 12 & 13 & 13 & 13 & 14 & 14 & 14 & 15 & 15 & 15 & 16 & 16 \\
\hline 575 & 10 & 11 & 11 & 11 & 12 & 12 & 12 & 13 & 13 & 13 & 14 & 14 & 14 & 15 & 15 & 15 & 16 & 16 \\
\hline 580 & 11 & 11 & 11 & 12 & 12 & 12 & 13 & 13 & 13 & 14 & 14 & 14 & 15 & 15 & 15 & 16 & 16 & 16 \\
\hline 585 & 11 & 11 & 11 & 12 & 12 & 12 & 13 & 13 & 13 & 14 & 14 & 14 & 15 & 15 & 15 & 16 & 16 & 17 \\
\hline 590 & 11 & 11 & 12 & 12 & 12 & 13 & 13 & 13 & 14 & 14 & 14 & 15 & 15 & 15 & 16 & 16 & 16 & 17 \\
\hline 595 & 11 & 11 & 12 & 12 & 12 & 13 & 13 & 13 & 14 & 14 & 14 & 15 & 15 & 15 & 16 & 16 & 16 & 17 \\
\hline 600 & 11 & 12 & 12 & 12 & 13 & 13 & 13 & 14 & 14 & 14 & 15 & 15 & 15 & 16 & 16 & 16 & 17 & 17 \\
\hline 605 & 11 & 12 & 12 & 12 & 13 & 13 & 13 & 14 & 14 & 14 & 15 & 15 & 15 & 16 & 16 & 16 & 17 & 17 \\
\hline 610 & 12 & 12 & 12 & 13 & 13 & 13 & 14 & 14 & 14 & 15 & 15 & 15 & 16 & 16 & 16 & 17 & 17 & 17 \\
\hline 615 & 12 & 12 & 12 & 13 & 13 & 13 & 14 & 14 & 14 & 15 & 15 & 15 & 16 & 16 & 16 & 17 & 17 & 17 \\
\hline 620 & 12 & 12 & 13 & 13 & 13 & 14 & 14 & 14 & 15 & 15 & 15 & 16 & 16 & 16 & 17 & 17 & 17 & 18 \\
\hline 625 & 12 & 12 & 13 & 13 & 13 & 14 & 14 & 14 & 15 & 15 & 15 & 16 & 16 & 16 & 17 & 17 & 17 & 18 \\
\hline 630 & 12 & 13 & 13 & 13 & 14 & 14 & 14 & 15 & 15 & 15 & 16 & 16 & 16 & 17 & 17 & 17 & 18 & 18 \\
\hline 635 & 12 & 13 & 13 & 13 & 14 & 14 & 14 & 15 & 15 & 15 & 16 & 16 & 16 & 17 & 17 & 17 & 18 & 18 \\
\hline 640 & 13 & 13 & 13 & 14 & 14 & 14 & 15 & 15 & 15 & 16 & 16 & 16 & 17 & 17 & 17 & 18 & 18 & 18 \\
\hline 645 & 13 & 13 & 13 & 14 & 14 & 14 & 15 & 15 & 15 & 16 & 16 & 16 & 17 & 17 & 17 & 18 & 18 & 18 \\
\hline 650 & 13 & 13 & 13 & 14 & 14 & 15 & 15 & 15 & 16 & 16 & 16 & 17 & 17 & 17 & 18 & 18 & 18 & 19 \\
\hline
\end{tabular}


Orta Anadolu Bölgesi’nde buğdayda Avrupa Sünesi (Eurygaster maura L. Hemiptera: Scutelleridae)’nin neden olduğu ürün kayıpları ve ekonomik zarar eşiğinin belirlenmesi

\section{EK 5}

Kabul edilebilir üst emgi oranı \%4'e göre dikkate alınması gereken ekonomik zarar eşiği değerleri

\begin{tabular}{|c|c|c|c|c|c|c|c|c|c|c|c|c|c|c|c|c|c|c|}
\hline \multirow{2}{*}{$\begin{array}{c}\text { Bitki sayısı } \\
{\text { (adet } \mathrm{m}^{-2} \text { ) }}^{\text {and }}\end{array}$} & \multicolumn{18}{|c|}{ Tane sayısı (adet başak ${ }^{-1}$ ) } \\
\hline & 17 & 18 & 19 & 20 & 21 & 22 & 23 & 24 & 25 & 26 & 27 & 28 & 29 & 30 & 31 & 32 & 33 & 34 \\
\hline 170 & 1 & 1 & 1 & 1 & 1 & 1 & 1 & 1 & 1 & 1 & 2 & 2 & 3 & 3 & 4 & 4 & 5 & 5 \\
\hline 175 & 1 & 1 & 1 & 1 & 1 & 1 & 1 & 1 & 1 & 1 & 2 & 2 & 3 & 3 & 4 & 4 & 5 & 5 \\
\hline 180 & 1 & 1 & 1 & 1 & 1 & 1 & 1 & 1 & 1 & 2 & 2 & 3 & 3 & 4 & 4 & 4 & 5 & 5 \\
\hline 185 & 1 & 1 & 1 & 1 & 1 & 1 & 1 & 1 & 1 & 2 & 2 & 3 & 3 & 4 & 4 & 5 & 5 & 6 \\
\hline 190 & 1 & 1 & 1 & 1 & 1 & 1 & 1 & 1 & 1 & 2 & 2 & 3 & 3 & 4 & 4 & 5 & 5 & 6 \\
\hline 195 & 1 & 1 & 1 & 1 & 1 & 1 & 1 & 1 & 2 & 2 & 3 & 3 & 4 & 4 & 4 & 5 & 6 & 6 \\
\hline 200 & 1 & 1 & 1 & 1 & 1 & 1 & 1 & 1 & 2 & 2 & 3 & 3 & 4 & 4 & 5 & 5 & 6 & 6 \\
\hline 205 & 1 & 1 & 1 & 1 & 1 & 1 & 1 & 2 & 2 & 3 & 3 & 3 & 4 & 4 & 5 & 5 & 6 & 6 \\
\hline 210 & 1 & 1 & 1 & 1 & 1 & 1 & 1 & 2 & 2 & 3 & 3 & 4 & 4 & 5 & 5 & 6 & 6 & 7 \\
\hline 215 & 1 & 1 & 1 & 1 & 1 & 1 & 1 & 2 & 2 & 3 & 3 & 4 & 4 & 5 & 5 & 6 & 6 & 7 \\
\hline 220 & 1 & 1 & 1 & 1 & 1 & 1 & 2 & 2 & 3 & 3 & 4 & 4 & 5 & 5 & 5 & 6 & 6 & 7 \\
\hline 225 & 1 & 1 & 1 & 1 & 1 & 1 & 2 & 2 & 3 & 3 & 4 & 4 & 5 & 5 & 6 & 6 & 7 & 7 \\
\hline 230 & 1 & 1 & 1 & 1 & 1 & 2 & 2 & 2 & 3 & 3 & 4 & 4 & 5 & 5 & 6 & 6 & 7 & 7 \\
\hline 235 & 1 & 1 & 1 & 1 & 1 & 2 & 2 & 3 & 3 & 4 & 4 & 5 & 5 & 6 & 6 & 6 & 7 & 8 \\
\hline 240 & 1 & 1 & 1 & 1 & 1 & 2 & 2 & 3 & 3 & 4 & 4 & 5 & 5 & 6 & 6 & 7 & 7 & 8 \\
\hline 245 & 1 & 1 & 1 & 1 & 2 & 2 & 3 & 3 & 3 & 4 & 4 & 5 & 5 & 6 & 6 & 7 & 7 & 8 \\
\hline 250 & 1 & 1 & 1 & 1 & 2 & 2 & 3 & 3 & 4 & 4 & 5 & 5 & 6 & 6 & 7 & 7 & 8 & 8 \\
\hline 255 & 1 & 1 & 1 & 1 & 2 & 2 & 3 & 3 & 4 & 4 & 5 & 5 & 6 & 6 & 7 & 7 & 8 & 8 \\
\hline 260 & 1 & 1 & 1 & 2 & 2 & 3 & 3 & 4 & 4 & 5 & 5 & 5 & 6 & 6 & 7 & 7 & 8 & 8 \\
\hline 265 & 1 & 1 & 1 & 2 & 2 & 3 & 3 & 4 & 4 & 5 & 5 & 6 & 6 & 7 & 7 & 8 & 8 & 9 \\
\hline 270 & 1 & 1 & 2 & 2 & 2 & 3 & 3 & 4 & 4 & 5 & 5 & 6 & 6 & 7 & 7 & 8 & 8 & 9 \\
\hline 275 & 1 & 1 & 2 & 2 & 3 & 3 & 4 & 4 & 5 & 5 & 6 & 6 & 6 & 7 & 7 & 8 & 8 & 9 \\
\hline 280 & 1 & 1 & 2 & 2 & 3 & 3 & 4 & 4 & 5 & 5 & 6 & 6 & 7 & 7 & 8 & 8 & 9 & 9 \\
\hline 285 & 1 & 2 & 2 & 3 & 3 & 4 & 4 & 4 & 5 & 5 & 6 & 6 & 7 & 7 & 8 & 8 & 9 & 9 \\
\hline 290 & 1 & 2 & 2 & 3 & 3 & 4 & 4 & 5 & 5 & 6 & 6 & 7 & 7 & 8 & 8 & 8 & 9 & 9 \\
\hline 295 & 1 & 2 & 2 & 3 & 3 & 4 & 4 & 5 & 5 & 6 & 6 & 7 & 7 & 8 & 8 & 9 & 9 & 10 \\
\hline 300 & 2 & 2 & 3 & 3 & 4 & 4 & 5 & 5 & 5 & 6 & 6 & 7 & 7 & 8 & 8 & 9 & 9 & 10 \\
\hline 305 & 2 & 2 & 3 & 3 & 4 & 4 & 5 & 5 & 6 & 6 & 7 & 7 & 8 & 8 & 9 & 9 & 10 & 10 \\
\hline 310 & 2 & 2 & 3 & 3 & 4 & 4 & 5 & 5 & 6 & 6 & 7 & 7 & 8 & 8 & 9 & 9 & 10 & 10 \\
\hline 315 & 2 & 3 & 3 & 4 & 4 & 5 & 5 & 6 & 6 & 7 & 7 & 7 & 8 & 8 & 9 & 9 & 10 & 10 \\
\hline 320 & 2 & 3 & 3 & 4 & 4 & 5 & 5 & 6 & 6 & 7 & 7 & 8 & 8 & 9 & 9 & 10 & 10 & 11 \\
\hline 325 & 3 & 3 & 4 & 4 & 4 & 5 & 5 & 6 & 6 & 7 & 7 & 8 & 8 & 9 & 9 & 10 & 10 & 11 \\
\hline 330 & 3 & 3 & 4 & 4 & 5 & 5 & 6 & 6 & 7 & 7 & 8 & 8 & 8 & 9 & 9 & 10 & 10 & 11 \\
\hline 335 & 3 & 3 & 4 & 4 & 5 & 5 & 6 & 6 & 7 & 7 & 8 & 8 & 9 & 9 & 10 & 10 & 11 & 11 \\
\hline 340 & 3 & 4 & 4 & 5 & 5 & 5 & 6 & 6 & 7 & 7 & 8 & 8 & 9 & 9 & 10 & 10 & 11 & 11 \\
\hline 345 & 3 & 4 & 4 & 5 & 5 & 6 & 6 & 7 & 7 & 8 & 8 & 9 & 9 & 10 & 10 & 10 & 11 & 11 \\
\hline 350 & 3 & 4 & 4 & 5 & 5 & 6 & 6 & 7 & 7 & 8 & 8 & 9 & 9 & 10 & 10 & 11 & 11 & 12 \\
\hline 355 & 4 & 4 & 5 & 5 & 6 & 6 & 7 & 7 & 7 & 8 & 8 & 9 & 9 & 10 & 10 & 11 & 11 & 12 \\
\hline 360 & 4 & 4 & 5 & 5 & 6 & 6 & 7 & 7 & 8 & 8 & 9 & 9 & 10 & 10 & 11 & 11 & 11 & 12 \\
\hline 365 & 4 & 4 & 5 & 5 & 6 & 6 & 7 & 7 & 8 & 8 & 9 & 9 & 10 & 10 & 11 & 11 & 12 & 12 \\
\hline 370 & 4 & 5 & 5 & 6 & 6 & 7 & 7 & 8 & 8 & 9 & 9 & 9 & 10 & 10 & 11 & 11 & 12 & 12 \\
\hline 375 & 4 & 5 & 5 & 6 & 6 & 7 & 7 & 8 & 8 & 9 & 9 & 10 & 10 & 11 & 11 & 12 & 12 & 13 \\
\hline 380 & 5 & 5 & 6 & 6 & 6 & 7 & 7 & 8 & 8 & 9 & 9 & 10 & 10 & 11 & 11 & 12 & 12 & 13 \\
\hline 385 & 5 & 5 & 6 & 6 & 7 & 7 & 8 & 8 & 9 & 9 & 10 & 10 & 10 & 11 & 11 & 12 & 12 & 13 \\
\hline 390 & 5 & 5 & 6 & 6 & 7 & 7 & 8 & 8 & 9 & 9 & 10 & 10 & 11 & 11 & 12 & 12 & 13 & 13 \\
\hline 395 & 5 & 6 & 6 & 7 & 7 & 7 & 8 & 8 & 9 & 9 & 10 & 10 & 11 & 11 & 12 & 12 & 13 & 13 \\
\hline 400 & 5 & 6 & 6 & 7 & 7 & 8 & 8 & 9 & 9 & 10 & 10 & 11 & 11 & 11 & 12 & 12 & 13 & 13 \\
\hline 405 & 5 & 6 & 6 & 7 & 7 & 8 & 8 & 9 & 9 & 10 & 10 & 11 & 11 & 12 & 12 & 13 & 13 & 14 \\
\hline 410 & 6 & 6 & 7 & 7 & 8 & 8 & 9 & 9 & 9 & 10 & 10 & 11 & 11 & 12 & 12 & 13 & 13 & 14 \\
\hline
\end{tabular}




\section{EK 5 Devam}

Kabul edilebilir üst emgi oranı \%4'e göre dikkate alınması gereken ekonomik zarar eşiği değerleri

\begin{tabular}{|c|c|c|c|c|c|c|c|c|c|c|c|c|c|c|c|c|c|c|}
\hline \multirow{2}{*}{ 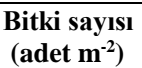 } & \multicolumn{18}{|c|}{ Tane sayısı (adet başak ${ }^{-1}$ ) } \\
\hline & 17 & 18 & 19 & 20 & 21 & 22 & 23 & 24 & 25 & 26 & 27 & 28 & 29 & 30 & 31 & 32 & 33 & 34 \\
\hline 415 & 6 & 6 & 7 & 7 & 8 & 8 & 9 & 9 & 10 & 10 & 11 & 11 & 12 & 12 & 13 & 13 & 13 & 14 \\
\hline 420 & 6 & 6 & 7 & 7 & 8 & 8 & 9 & 9 & 10 & 10 & 11 & 11 & 12 & 12 & 13 & 13 & 14 & 14 \\
\hline 425 & 6 & 7 & 7 & 8 & 8 & 9 & 9 & 10 & 10 & 11 & 11 & 11 & 12 & 12 & 13 & 13 & 14 & 14 \\
\hline 430 & 6 & 7 & 7 & 8 & 8 & 9 & 9 & 10 & 10 & 11 & 11 & 12 & 12 & 13 & 13 & 14 & 14 & 15 \\
\hline 435 & 7 & 7 & 8 & 8 & 8 & 9 & 9 & 10 & 10 & 11 & 11 & 12 & 12 & 13 & 13 & 14 & 14 & 15 \\
\hline 440 & 7 & 7 & 8 & 8 & 9 & 9 & 10 & 10 & 10 & 11 & 12 & 12 & 12 & 13 & 14 & 14 & 14 & 15 \\
\hline 445 & 7 & 7 & 8 & 8 & 9 & 9 & 10 & 10 & 11 & 11 & 12 & 12 & 13 & 13 & 14 & 14 & 15 & 15 \\
\hline 450 & 7 & 8 & 8 & 9 & 9 & 9 & 10 & 10 & 11 & 11 & 12 & 12 & 13 & 13 & 14 & 14 & 15 & 15 \\
\hline 455 & 7 & 8 & 8 & 9 & 9 & 10 & 10 & 11 & 11 & 12 & 12 & 13 & 13 & 14 & 14 & 14 & 15 & 15 \\
\hline 460 & 7 & 8 & 8 & 9 & 9 & 10 & 10 & 11 & 11 & 12 & 12 & 13 & 13 & 14 & 14 & 15 & 15 & 16 \\
\hline 465 & 8 & 8 & 9 & 9 & 10 & 10 & 11 & 11 & 11 & 12 & 12 & 13 & 13 & 14 & 14 & 15 & 15 & 16 \\
\hline 470 & 8 & 8 & 9 & 9 & 10 & 10 & 11 & 11 & 12 & 12 & 13 & 13 & 14 & 14 & 15 & 15 & 15 & 16 \\
\hline 475 & 8 & 8 & 9 & 9 & 10 & 10 & 11 & 11 & 12 & 12 & 13 & 13 & 14 & 14 & 15 & 15 & 16 & 16 \\
\hline 480 & 8 & 9 & 9 & 10 & 10 & 11 & 11 & 12 & 12 & 12 & 13 & 13 & 14 & 14 & 15 & 15 & 16 & 16 \\
\hline 485 & 8 & 9 & 9 & 10 & 10 & 11 & 11 & 12 & 12 & 13 & 13 & 14 & 14 & 15 & 15 & 16 & 16 & 17 \\
\hline 490 & 9 & 9 & 10 & 10 & 10 & 11 & 11 & 12 & 12 & 13 & 13 & 14 & 14 & 15 & 15 & 16 & 16 & 17 \\
\hline 495 & 9 & 9 & 10 & 10 & 11 & 11 & 12 & 12 & 13 & 13 & 14 & 14 & 14 & 15 & 15 & 16 & 16 & 17 \\
\hline 500 & 9 & 9 & 10 & 10 & 11 & 11 & 12 & 12 & 13 & 13 & 14 & 14 & 15 & 15 & 16 & 16 & 17 & 17 \\
\hline 505 & 9 & 10 & 10 & 11 & 11 & 11 & 12 & 12 & 13 & 13 & 14 & 14 & 15 & 15 & 16 & 16 & 17 & 17 \\
\hline 510 & 9 & 10 & 10 & 11 & 11 & 12 & 12 & 13 & 13 & 14 & 14 & 15 & 15 & 16 & 16 & 16 & 17 & 17 \\
\hline 515 & 9 & 10 & 10 & 11 & 11 & 12 & 12 & 13 & 13 & 14 & 14 & 15 & 15 & 16 & 16 & 17 & 17 & 18 \\
\hline 520 & 10 & 10 & 11 & 11 & 12 & 12 & 13 & 13 & 13 & 14 & 14 & 15 & 15 & 16 & 16 & 17 & 17 & 18 \\
\hline 525 & 10 & 10 & 11 & 11 & 12 & 12 & 13 & 13 & 14 & 14 & 15 & 15 & 16 & 16 & 17 & 17 & 17 & 18 \\
\hline 530 & 10 & 10 & 11 & 11 & 12 & 12 & 13 & 13 & 14 & 14 & 15 & 15 & 16 & 16 & 17 & 17 & 18 & 18 \\
\hline 535 & 10 & 11 & 11 & 12 & 12 & 13 & 13 & 14 & 14 & 14 & 15 & 15 & 16 & 16 & 17 & 17 & 18 & 18 \\
\hline 540 & 10 & 11 & 11 & 12 & 12 & 13 & 13 & 14 & 14 & 15 & 15 & 16 & 16 & 17 & 17 & 18 & 18 & 19 \\
\hline 545 & 11 & 11 & 11 & 12 & 12 & 13 & 13 & 14 & 14 & 15 & 15 & 16 & 16 & 17 & 17 & 18 & 18 & 19 \\
\hline 550 & 11 & 11 & 12 & 12 & 13 & 13 & 14 & 14 & 15 & 15 & 16 & 16 & 16 & 17 & 17 & 18 & 18 & 19 \\
\hline 555 & 11 & 11 & 12 & 12 & 13 & 13 & 14 & 14 & 15 & 15 & 16 & 16 & 17 & 17 & 18 & 18 & 19 & 19 \\
\hline 560 & 11 & 12 & 12 & 13 & 13 & 13 & 14 & 14 & 15 & 15 & 16 & 16 & 17 & 17 & 18 & 18 & 19 & 19 \\
\hline 565 & 11 & 12 & 12 & 13 & 13 & 14 & 14 & 15 & 15 & 16 & 16 & 17 & 17 & 17 & 18 & 18 & 19 & 19 \\
\hline 570 & 11 & 12 & 12 & 13 & 13 & 14 & 14 & 15 & 15 & 16 & 16 & 17 & 17 & 18 & 18 & 19 & 19 & 20 \\
\hline 575 & 12 & 12 & 13 & 13 & 14 & 14 & 15 & 15 & 15 & 16 & 16 & 17 & 17 & 18 & 18 & 19 & 19 & 20 \\
\hline 580 & 12 & 12 & 13 & 13 & 14 & 14 & 15 & 15 & 16 & 16 & 17 & 17 & 18 & 18 & 19 & 19 & 19 & 20 \\
\hline 585 & 12 & 12 & 13 & 13 & 14 & 14 & 15 & 15 & 16 & 16 & 17 & 17 & 18 & 18 & 19 & 19 & 20 & 20 \\
\hline 590 & 12 & 13 & 13 & 14 & 14 & 15 & 15 & 16 & 16 & 16 & 17 & 17 & 18 & 18 & 19 & 19 & 20 & 20 \\
\hline 595 & 12 & 13 & 13 & 14 & 14 & 15 & 15 & 16 & 16 & 17 & 17 & 18 & 18 & 19 & 19 & 20 & 20 & 21 \\
\hline 600 & 13 & 13 & 13 & 14 & 14 & 15 & 15 & 16 & 16 & 17 & 17 & 18 & 18 & 19 & 19 & 20 & 20 & 21 \\
\hline 605 & 13 & 13 & 14 & 14 & 15 & 15 & 16 & 16 & 17 & 17 & 18 & 18 & 18 & 19 & 19 & 20 & 20 & 21 \\
\hline 610 & 13 & 13 & 14 & 14 & 15 & 15 & 16 & 16 & 17 & 17 & 18 & 18 & 19 & 19 & 20 & 20 & 21 & 21 \\
\hline 615 & 13 & 14 & 14 & 15 & 15 & 15 & 16 & 16 & 17 & 17 & 18 & 18 & 19 & 19 & 20 & 20 & 21 & 21 \\
\hline 620 & 13 & 14 & 14 & 15 & 15 & 16 & 16 & 17 & 17 & 18 & 18 & 19 & 19 & 19 & 20 & 20 & 21 & 21 \\
\hline 625 & 13 & 14 & 14 & 15 & 15 & 16 & 16 & 17 & 17 & 18 & 18 & 19 & 19 & 20 & 20 & 21 & 21 & 22 \\
\hline 630 & 14 & 14 & 15 & 15 & 16 & 16 & 16 & 17 & 17 & 18 & 18 & 19 & 19 & 20 & 20 & 21 & 21 & 22 \\
\hline 635 & 14 & 14 & 15 & 15 & 16 & 16 & 17 & 17 & 18 & 18 & 19 & 19 & 20 & 20 & 21 & 21 & 22 & 22 \\
\hline 640 & 14 & 14 & 15 & 15 & 16 & 16 & 17 & 17 & 18 & 18 & 19 & 19 & 20 & 20 & 21 & 21 & 22 & 22 \\
\hline 645 & 14 & 15 & 15 & 16 & 16 & 17 & 17 & 18 & 18 & 18 & 19 & 19 & 20 & 20 & 21 & 21 & 22 & 22 \\
\hline 650 & 14 & 15 & 15 & 16 & 16 & 17 & 17 & 18 & 18 & 19 & 19 & 20 & 20 & 21 & 21 & 22 & 22 & 22 \\
\hline
\end{tabular}

